
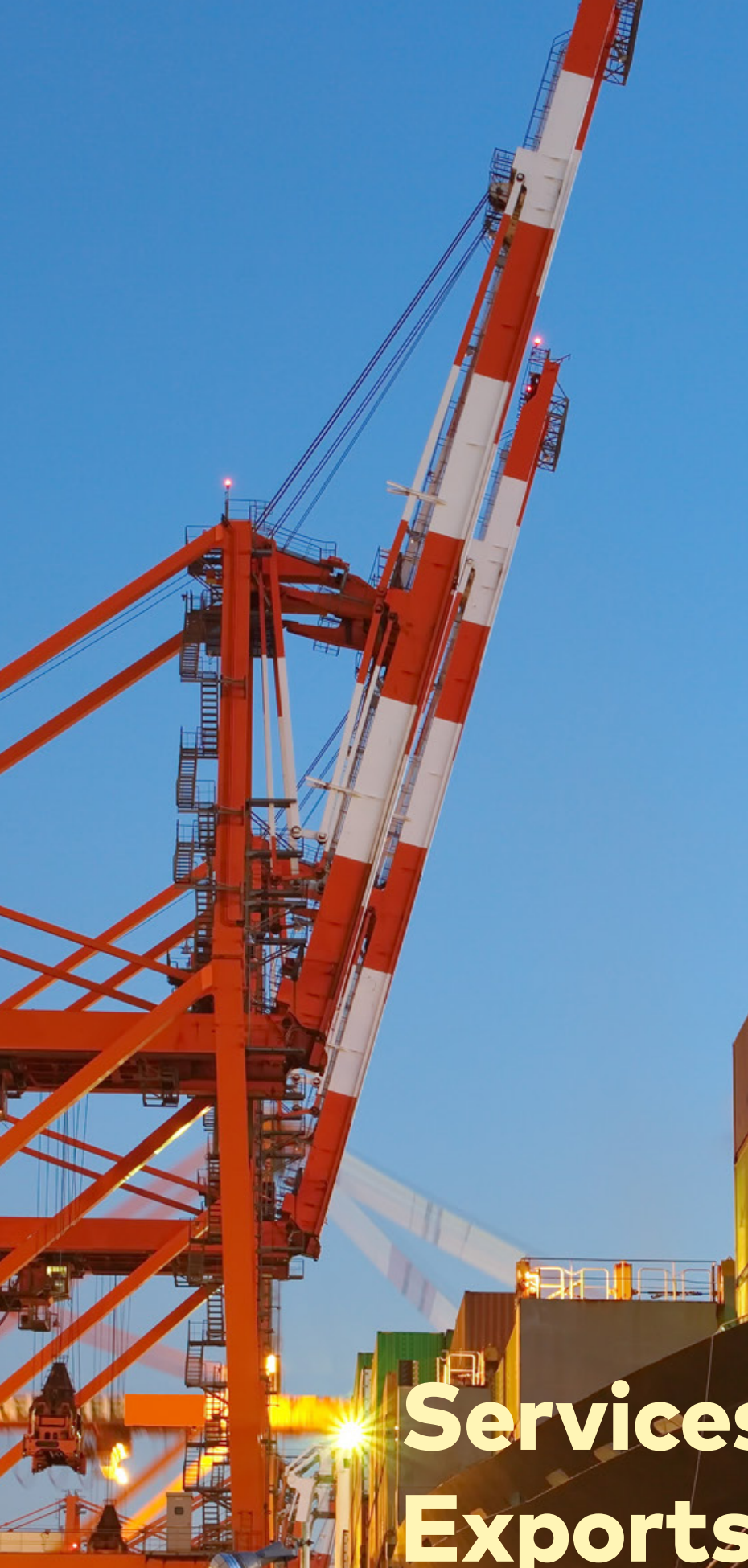

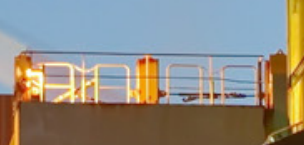
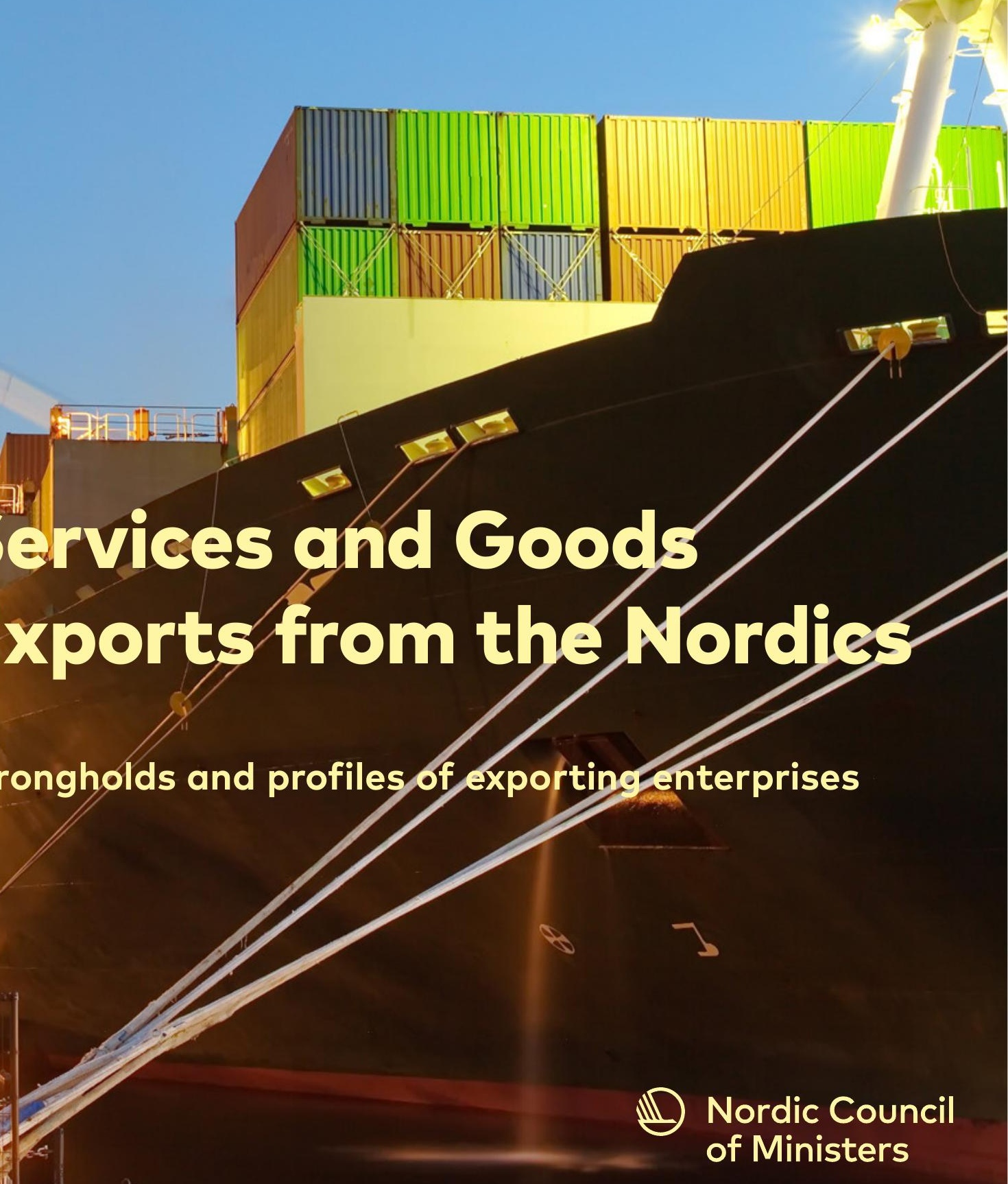



\section{Services and Goods Exports from the Nordics}

Strongholds and profiles of exporting enterprises

TemaNord 2016:555 
Services and Goods Exports from the Nordics

Strongholds and profiles of exporting enterprises

ISBN 978-92-893-4760-0 (PRINT)

ISBN 978-92-893-4761-7 (PDF)

ISBN 978-92-893-4762-4 (EPUB)

http://dx.doi.org/10.6027/TN2016-555

TemaNord 2016:555

ISSN 0.908-6692

Standard: PDF/UA-1

ISO 14289-1

(c) Nordic Council of Ministers 2016

Layout: Hanne Lebech

Cover photo: Scanpix

Print: Rosendahls-Schultz Grafisk

Printed in Denmark

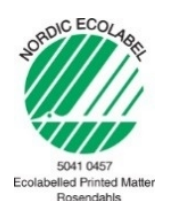

Although the Nordic Council of Ministers funded this publication, the contents do not necessarily reflect its views, policies or recommendations.

\section{Nordic co-operation}

Nordic co-operation is one of the world's most extensive forms of regional collaboration, involving Denmark, Finland, Iceland, Norway, Sweden, the Faroe Islands, Greenland, and Åland.

Nordic co-operation has firm traditions in politics, the economy, and culture. It plays an important role in European and international collaboration, and aims at creating a strong Nordic community in a strong Europe.

Nordic co-operation seeks to safeguard Nordic and regional interests and principles in the global community. Shared Nordic values help the region solidify its position as one of the world's most innovative and competitive. 


\section{Contents}

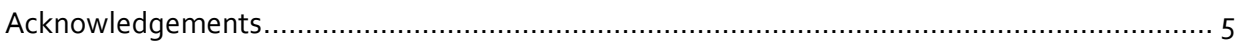

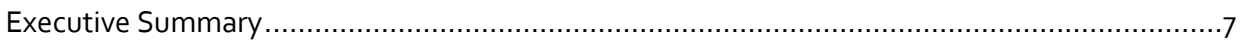

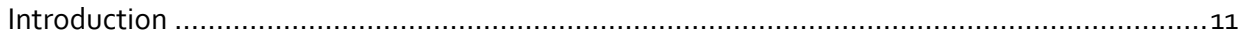

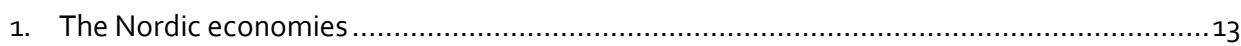

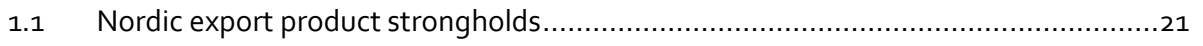

2. International trade in services in the Nordic countries ............................................. 25

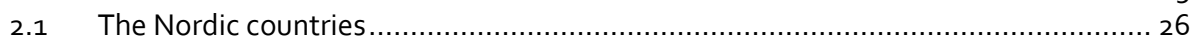

2.1.1 Part I. Trade patterns and market trends ............................................ 26

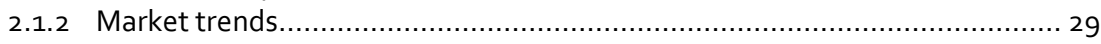

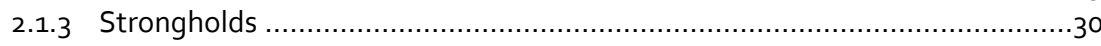

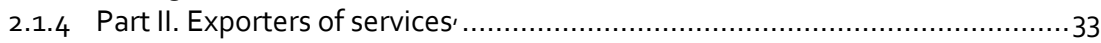

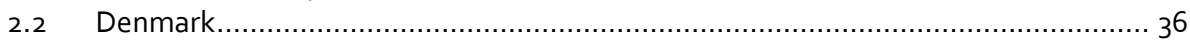

2.2.1 Part I. Trade patterns and market trends ........................................... 36

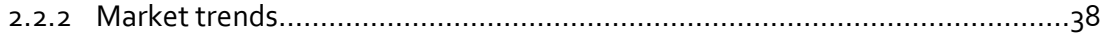

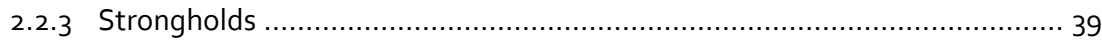

2.2.4 Part II. Exporters of services....................................................... 40

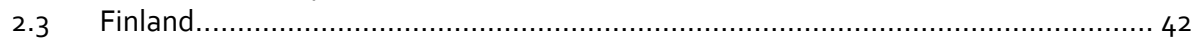

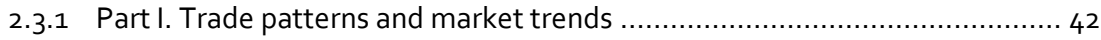

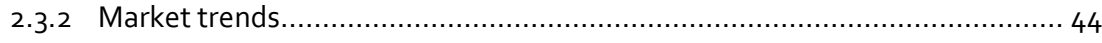

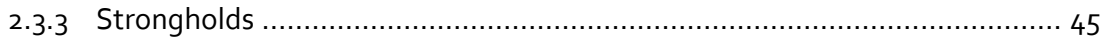

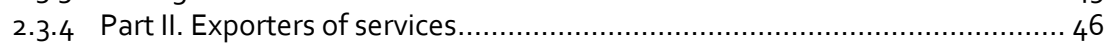

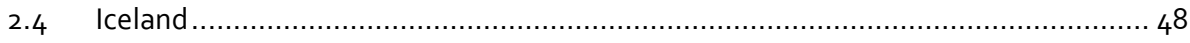

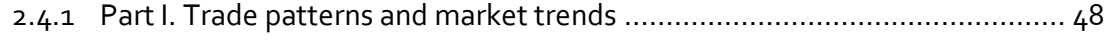

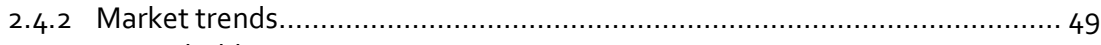

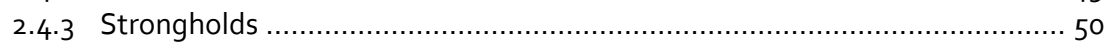

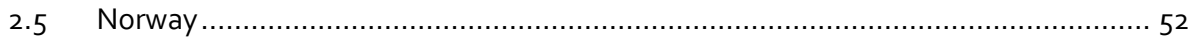

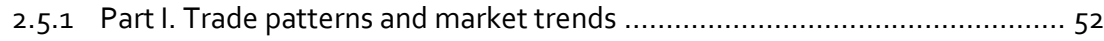

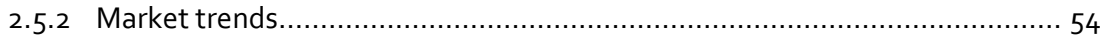

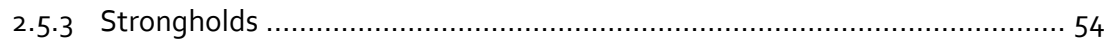

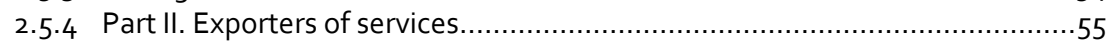

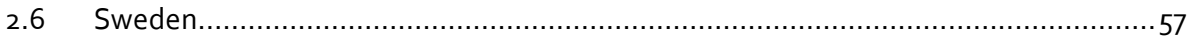

2.6.1 Part I. Trade patterns and market trends …........................................ 57

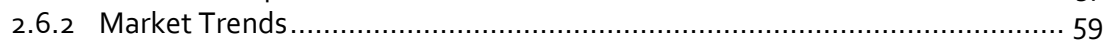

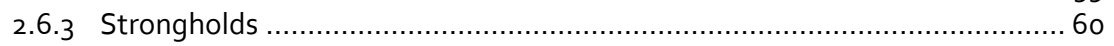

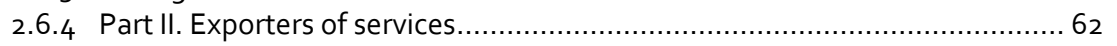




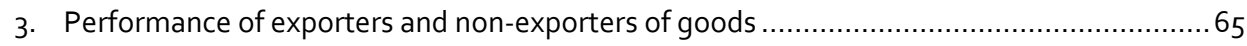

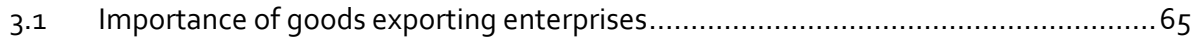

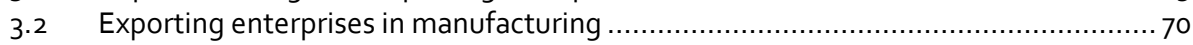

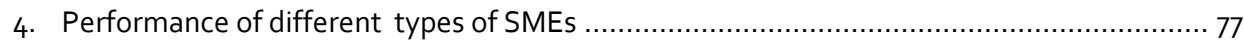

4.1 Small and Medium sized Enterprises and growth ....................................... 78

5. Performance of domestically and foreign owned enterprises .................................. 87

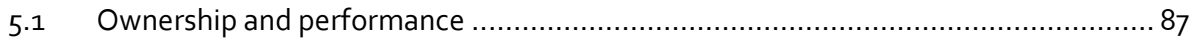

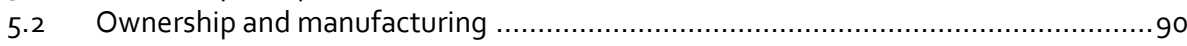

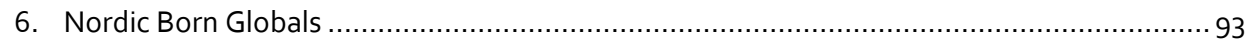

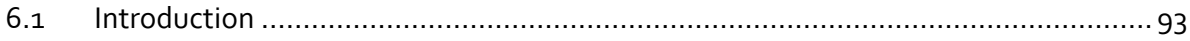

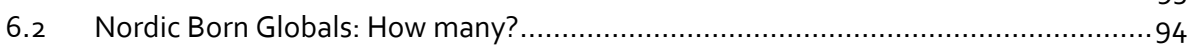

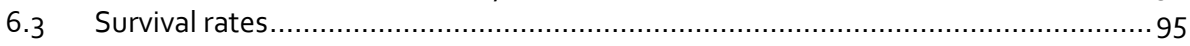

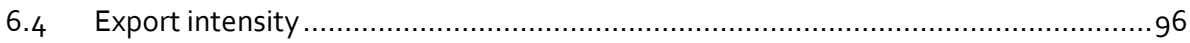

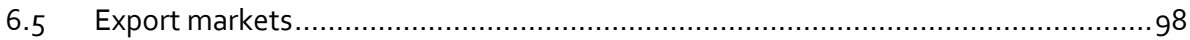

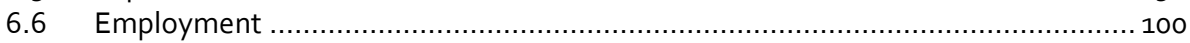

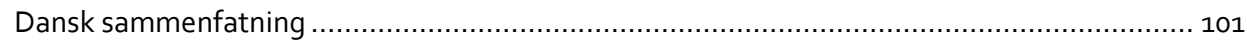

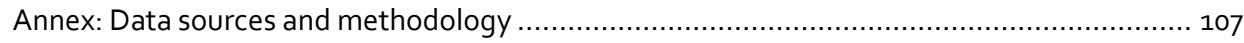

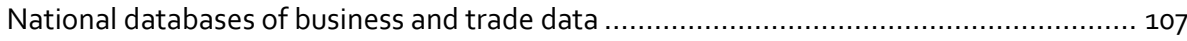

International trade in goods data.......................................................................... 108

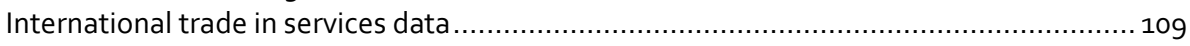

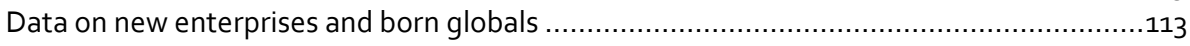

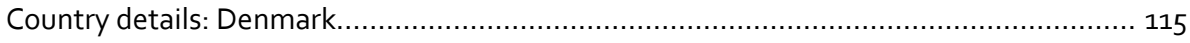

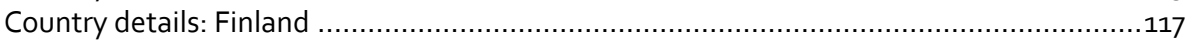

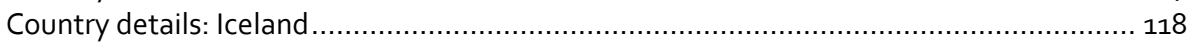

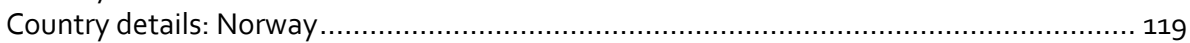

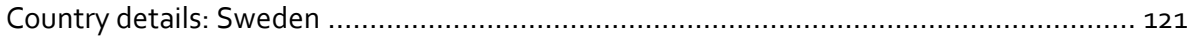




\section{Acknowledgements}

The project Profiling Nordic enterprises in Global Value Chains has been carried out by the Nordic national statistical institutes in Denmark, Finland, Iceland, Norway and Sweden, in addition to the OECD. The project has been funded by the Nordic Council of Ministers.

This publication Services and Goods Exports from the Nordics - Strongholds and profiles of exporting enterprises contains the first comparative analysis of international trade and services from the Nordic countries, including a profiling of services exporters. Furthermore, the publication is based on harmonised national databases holding statistical information at enterprise level from statistical registers covering variables from structural business statistics, business register, international trade in goods and services and business demography. Statistics Denmark coordinated the project and the project group consisted of the following persons:

- Statistics Denmark: Peter Bøegh Nielsen (Chairman), Michael E. Nielsen, Flemming von Hadeln Løve, Jon Mortensen, Kamilla Elkjær, Søren Burman and Caroline Bo.

- Statistics Finland: Henri Luomaranta, Lauri Saarinen and Olli-Jussi Sonni.

- Statistics Iceland: Gísli Már Gíslason, Valgeir Geirsson and Magnus Bergmann.

- Statistics Norway: Øyvind Hagen and Jan Olav Rørhus.

- Statistics Sweden: Andreas Poldahl and Claes Petri.

In another part of the project, the above group worked together with the OECD to produce, based on the national databases, a series of new national tables on firm heterogeneity, to be used as input to improve Trade in Value Added (TiVA) database established by OECD and WTO. The results of this work are published in a separate report The Nordic countries in Global Value Chains. 



\section{Executive Summary}

This analysis is a follow-up to the 2014 publication Nordic Exports of Goods and Exporting Enterprise. ${ }^{1}$ In addition to providing an update of the previous analysis, the present report contributes with new knowledge about different aspects of Nordic enterprises' and involvement in globalization and global value chains:

- This time the analysis also includes international trade in services which is of increasing importance to the Nordic countries.

- The analysis also includes a profiling of the enterprises carrying out international trade in services, which is the first comparative analysis of its kind internationally.

- The goods exporting enterprises in the Nordics are further analysed from the perspective of firm heterogeneity and its impact on their performance: enterprise size (focusing on SMEs), nationality of ownership, and age (internationally oriented new enterprises, the so-called born globals).

Chapter 1 provides an overview of the Nordic economies with a focus on trade and exportsstrongholds (for goods). The Nordics are among the world's wealthiest countries, but economic growth has been sluggish following the crisis in 2008 .

All Nordic countries, except Iceland, were less exposed to trade in 2015 than in 2008 (measured by the trade to GDP ratio). A development they shared with only two other EU-countries (Malta and the UK). In 2015, the value of the Nordic countries' total exports of goods and services was EUR 557 billion (or 8.7\% total EU-28 exports). Goods made-up $67 \%$ and services $33 \%$.

The combined value of the Nordic countries' exports of goods was EUR 364 billion in 2015. This was EUR 23 billion lower than in 2008, and EUR 38 billion lower than in 2012 , the latest peak year. The EU is by far the largest trade partner for all of the Nordic countries. Norway and Iceland are particularly dependent on the EU as export destination; each sending more than $70 \%$ of total goods exports to a non-Nordic EU-country.

${ }^{1}$ Nordic Exports of Goods and Exporting Enterprise published by Nordic Council of Ministers 2014 as a result of a joint project between Statistics Denmark, Statistics Finland, Statistics Iceland, Statistics Norway and Statistics Sweden. 
The Nordic region as export destination (for goods) is most important to Denmark and Sweden and least important to Iceland. In 2015 , $24 \%$ of Sweden's and $21 \%$ of Denmark's goods exports (in value terms) were to another Nordic country, while the same was true for only $8 \%$ of Iceland's goods exports.

Petroleum and petroleum products is the most important Nordic export product group accounting for EUR 43 billion or $12 \%$ of total Nordic goods exports in 2015. Other Nordic export strongholds include Fish, Paper and paperboard and Power-generating machinery.

Chapter 2 presents the first cross-Nordic analysis of trade in services and the enterprises behind. Sweden is the largest Nordic services exporter with total exports of services of EUR 56.6 billion in 2014. Denmark exported slightly less with services amounting to EUR 54.9 billion. The other Nordic countries exported significantly less, as Norway exported EUR 37.8 billion, Finland EUR 21.2 billion, and Iceland EUR 3.2 billion.

Between 2010 and 2014 the development in exports of services has differed among the Nordic countries. Iceland experienced an increase in exports of $42 \%$. In the same period the service exports of Sweden grew 38\%, Norway 20\%, Denmark 18\%, and Finland $1 \%$. In comparison, total EU28 exports of services rose $29 \%$.

Trade between the Nordic countries is considerable. On average, about one-fifth of the countries' exports consists of trade in services with other Nordic countries. Service exports from the Nordic countries are concentrated on a few services. Transport services is the most important service category in Nordic exports, accounting for $32.4 \%$ of total Nordic service exports in 2014. Nordic exports of transport services accounted for as much as $17.9 \%$ of EU28 transport service exports in 2014 . Other strongholds include Telecommunication and Construction services.

In all Nordic countries more than half of service exports are carried out by domestically controlled enterprises. The importance of the SMEs in the service exports increased in Denmark and Finland from 2010 to 2014.

Chapter 3 concerns exporting and non-exporting enterprises and focuses, in part, on the manufacturing sector. Goods exporting enterprises contribute significantly to employment and value added in the Nordic countries. Exporters are most important in Denmark, accounting for $27 \%$ of employment in the non-financial market sector and $32 \%$ of total gross value added in 2014 .

Exporters in manufacturing account for a very high share of the total exports of goods from each of the Nordic countries, and they also account for the majority of employment within manufacturing, except in Norway. Since 2008, however, exporting enterprises in manufacturing lost more jobs than the non-exporting ones in Denmark, Finland and Sweden. The opposite development can be observed for Norway. In total, the exporting manufacturing enterprises in these four Nordic countries lost more than 
200,000 full time employees in the period 2008 to 2014 - or $20 \%$ of total employment in manufacturing exporters in 2008.

The exporting enterprises are more productive than the non-exporting enterprises within manufacturing. In Denmark, Finland, Norway and Sweden the gross value added generated per employee is considerably higher for exporters than nonexporters. Furthermore, in all four countries the value added per employee in exporting enterprises developed more positively than in the non-exporting ones, in particular in Denmark.

The geographical pattern of exports is relatively similar across the Nordic countries. Around $15 \%$ of manufacturing exports go to the Nordic region, while the remaining EU constitutes the largest market area with 44 to $49 \%$ of total manufacturing exports from the Nordic countries.

Chapter 4 provides new knowledge on Small and Medium sized Enterprises (SMEs), which are normally seen as important vehicles for economic growth and job creation, and in enterprise policy shaping often combined with an assumption that SMEs come with a considerable export potential. In this analysis, we use new data and refine the traditional statistical definition of SMEs (based on employment within the enterprise itself), taking into account enterprise group dependency and external ownership relations to focus on independent SMEs, dependent SMEs and SMEs belonging to large groups (large group SMEs), see chapter 4 for definitions.

In all Nordic countries, independent SMEs make up the vast majority of enterprises and also account for more than half of total SME employment. However, large group SMEs, which account for less than $5 \%$ of all SMEs, account for around one third of total SME employment in the Nordics. The same pattern is found when looking at gross value added. Furthermore, large group SMEs are especially important when it comes to exports, accounting for more than two thirds of total SME exports in Finland and for half in Denmark.

This new type of breakdown of SMEs is important for policy shaping because a considerable share of SME exports actually stems from these large group SMEs, which could more rightly be considered large enterprises, given their affiliation with other enterprises within the (large) group. Put another way, the importance of "true" SMEs for exports for the Nordic enterprises diminishes further as they only account for $26 \%$ of total exports of goods in Denmark, 20\% in Norway, and 12\% in Finland and Sweden.

Chapter 5 looks at firm heterogeneity in terms of nationality of ownership, distinguishing between domestically and foreign owned enterprises, and furthermore between domestically owned enterprises with or without foreign affiliates (domestic multinationals or not). 
Focusing on manufacturing, there is a varied picture across the Nordic countries as more than half of the goods exports from Sweden comes from foreign owned enterprises, with significantly lower shares in both Denmark and Finland. Danish exports are characterised by the high share of exports from domestic MNEs, due to the predominantly Danish ownership within key strongholds such as pharmaceutical products, while the Swedish stronghold of road vehicles has a high share of foreign owned producers. In Finland the domestically owned enterprises without foreign affiliates account for nearly half of manufacturing exports.

Perhaps surprisingly, the geographical distribution of the exports of foreign owned enterprises is not markedly different from that of the domestically owned enterprises. The only slight difference is a somewhat larger share of exports from foreign owned enterprises going to the BRIC markets, possibly indicating an integration into globally highly dispersed organisation of production by MNEs.

Chapter 6 presents the first cross-Nordic analysis of born globals, covering a total of 360,800 new enterprises born in the period 2008-2011. More than 9,100 of these are characterised as born globals based on the criterion of having exported goods in the birth year of the enterprise or in the subsequent year.

Born globals make up the highest share of new enterprises in Denmark and Iceland, and a markedly lower share of new enterprises in Finland, Sweden and Norway. There does not appear to have been a dramatic rise in the number of born globals created in the Nordic region in this period.

The analysis finds that the survival rate of born globals is considerably higher than that of other new enterprises - in all five countries.

Furthermore, the analysis shows that a considerable number of born globals begin to export already in their birth year - and it corroborates findings in other studies that very few of the other new enterprises begin to export goods later on, if they do not begin to do so already from early on.

Finally, the analysis shows that the average number of employees per born global is at least twice as high as in the other new enterprises - and that employment in born globals grows much more, too. 


\section{Introduction}

The participation of domestic enterprises in international trade is an important driver for economic growth and a source for economic welfare in our societies. Recent research has shown that enterprises engaged in international trade are generally larger and more productive than enterprises serving only domestic markets. ${ }^{2}$ Increased and detailed knowledge about enterprises engaged in international trade is thus important for policyshaping to create better framework conditions for enterprises to become engaged in international trade and global value chains.

Research on enterprises in international trade has, however, only to a lesser extent been based on internationally harmonised enterpriselevel datasets. This publication mitigates the lack of such data by presenting the results of a joint project involving the five Nordic statistical offices. The project has established tailormade national databases with harmonised contents in each of the Nordic countries on exporting enterprises. This innovative approach allows for new insights and comparative perspectives on the heterogeneity of Nordic enterprises in a globalised world.

The report is a follow up to the recent publication Nordic Exports of Goods and Exporting Enterprise, ${ }^{3}$ but it is not a mere update as it presents additional analytical aspects of Nordic enterprises involvement in international trade. These are:

- Trade in services. An issue of increasing importance for the Nordic countries. The report identifies the different strongholds of the Nordic countries in services trade.

- Profiling of service-trading enterprises. This is one of the first international comparative analyses of its kind analyzing the characteristics of enterprises engaged in exports of services.

\footnotetext{
2 M. Melitz, "The Impact of Trade on Intra-Industry Reallocations and Aggregate Industry Productivity", Econometrica 71(6), 2003 and Helpman, E. et al., "Export versus FDI with Heterogeneous Firms", The American Economic Review 94(1), 2004. See AB Bernard et al., The Empirics of Firm Heterogeneity and International Trade, NBER Working Paper No. 17627,2011 for a recent literature review.

3 Nordic Exports of Goods and Exporting Enterprise published by Nordic Council of Ministers 2014 as a result of a joint project between Statistics Denmark, Statistics Finland, Statistics Iceland, Statistics Norway and Statistics Sweden.
} 
- Goods exporting enterprises are analysed from the perspective of firm heterogeneity and its impact on the enterprise performance with focus on enterprise size particularly SMEs, nationality of ownership and so-called born globals.

Establishing firm-level databases is a new and promising tool in the statistical toolbox to get further insights into emerging and dynamic topics such as global value chains for policy makers and researchers. This project sets an example for how internationally harmonised databases can be established allowing for comparative analysis using firmlevel data. 


\section{The Nordic economies}

\section{Main findings}

- The Nordics are among the world's wealthiest countries, but economic growth has been sluggish following the crisis in 2008.

- All Nordic countries, except Iceland, were less exposed to trade in 2015 than in 2008 (measured by the trade to GDP ratio). Something they shared with only two other EU-countries (Malta and the UK).

- In 2015, the value of the Nordic countries' total exports of goods and services was EUR 557 billion (or $8.7 \%$ total EU-28 exports). Goods made-up $67 \%$ and services $33 \%$. The combined value of the Nordic countries' exports of goods was EUR 364 billion in 2015 . This was EUR 23 billion lower than in 2008 , and EUR 38 billion lower than in 2012, the latest peak year. The EU is by far the largest trade partner for all of the Nordic countries. Norway and Iceland are particularly dependent on the EU as export destination; each sending more than $70 \%$ of total goods exports to a non-Nordic EU-country.

- The Nordic region as export destination (for goods) is most important to Denmark and Sweden and least important to Iceland. In 2015, $24 \%$ of Sweden's and $21 \%$ of Denmark's goods exports (in value terms) were to another Nordic country, while the same was true for only $8 \%$ of Iceland's goods exports.

- Petroleum and petroleum products is the most important Nordic export product group) accounting for EUR 43 billion or $12 \%$ of total Nordic goods exports in 2015. Other Nordic export strongholds include Fish, Paper and paperboard and Power-generating machinery.

The about 26 million people in the Nordic countries enjoy some of the highest standards of living in the world. Measured by real GDP per capita Norway is wealthiest among the Nordics, and within the EU only Luxembourg is richer. Although the other Nordic countries' are less wealthy than Norway, they still cluster at the top. Denmark and Sweden have the third and fourth highest real GDP per capita in the EU, and Finland, with the lowest real GDP per capita among the Nordics, have the ninth highest among the 28 EU-countries.

All the Nordic countries were hit by the economic crisis, and some have not yet fully recovered. It took Sweden five years and Iceland seven years to regain their real GDP per capita levels of 2008, and Denmark, Finland and Norway were still below pre-crisis levels in 2015. So while the Nordics countries are among the world's wealthiest, economic growth has been sluggish following the economic crisis. 


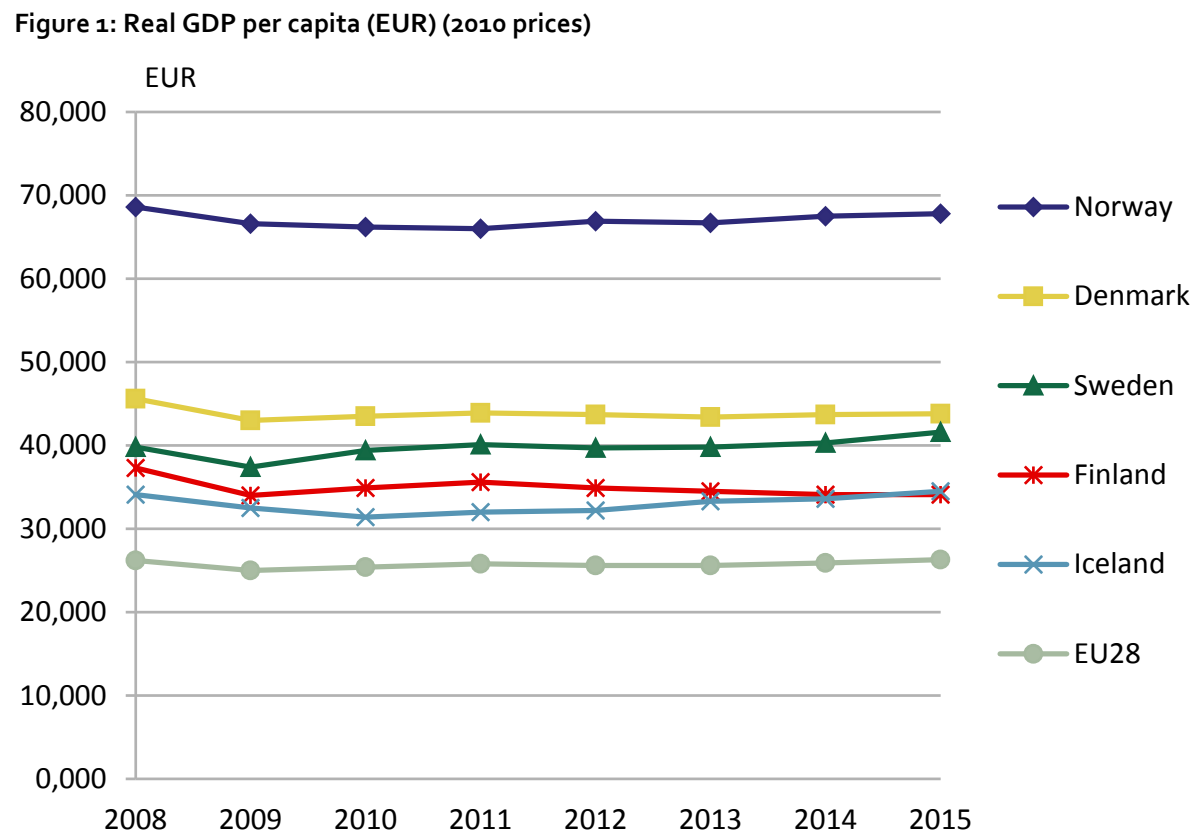

Source: Eurostat (table nama_10_pc).

Being open economies with small domestic markets, international trade is an important contributor to economic welfare for the Nordic countries.

Trade (the sum of exports and imports of goods and services) as a share of GDP - a common measure of trade openness - were highest in Denmark (101\%) and Iceland $(100 \%)$ and lowest in Norway (69\%) among the Nordics in 2015. Denmark and Iceland were also the most export oriented economies as both countries' exports of goods and services constituted $53 \%$ of GDP. Norway (37\%) was the least export-oriented Nordic country in 2015. In comparison, EU-28's trade in goods and services constituted $84 \%$ of its combined GDP, and Austria's, another small economy, 102\%, while the trade of the two much larger national economies, Germany and United Kingdom, constituted 86\% and $57 \%$ respectively. 
Figure 2: Trade in goods and services as percentage of GDP

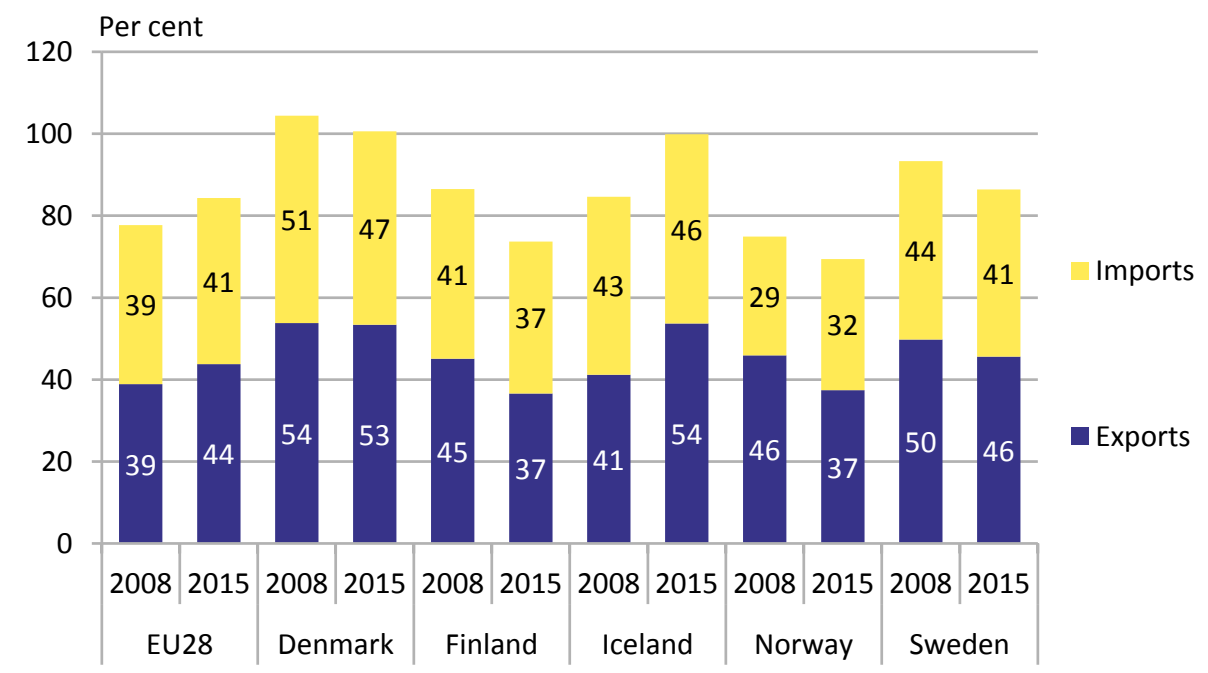

Source: Eurostat (table nama_10_gdp).

All Nordic countries, except Iceland, were less exposed to trade in 2015 than in 2008 (measured by the trade to GDP ratio). Something they shared with only two other EUcountries (Malta and the UK). This development follows significant drops in the Nordic countries' exports of goods and services following the economic crisis. In current prices, both Finland's and Norway's exports of goods and services fell 25\% from 2008, the peak year, to 2009; Sweden's exports fell by $22 \%$ while Denmark's exports fell $17 \%$ In comparison, the exports of goods and services of the EU-28 fell by $16 \%$ Iceland's exports peaked in 2007 and fell $14 \%$ the year after.

As the only Nordic country, Finland has yet to reach its pre-crisis export level, whereas Denmark, Iceland, Norway and Sweden all reached theirs within three years. However, in recent years markedly falling oil prices have caused a decline in the value of Norway's exports, and in 2015 its total exports fell below the pre-crisis level. Iceland's accelerating exports is caused by, among other things, a growing number of visiting tourists. 
Figure 3: Exports of goods and services

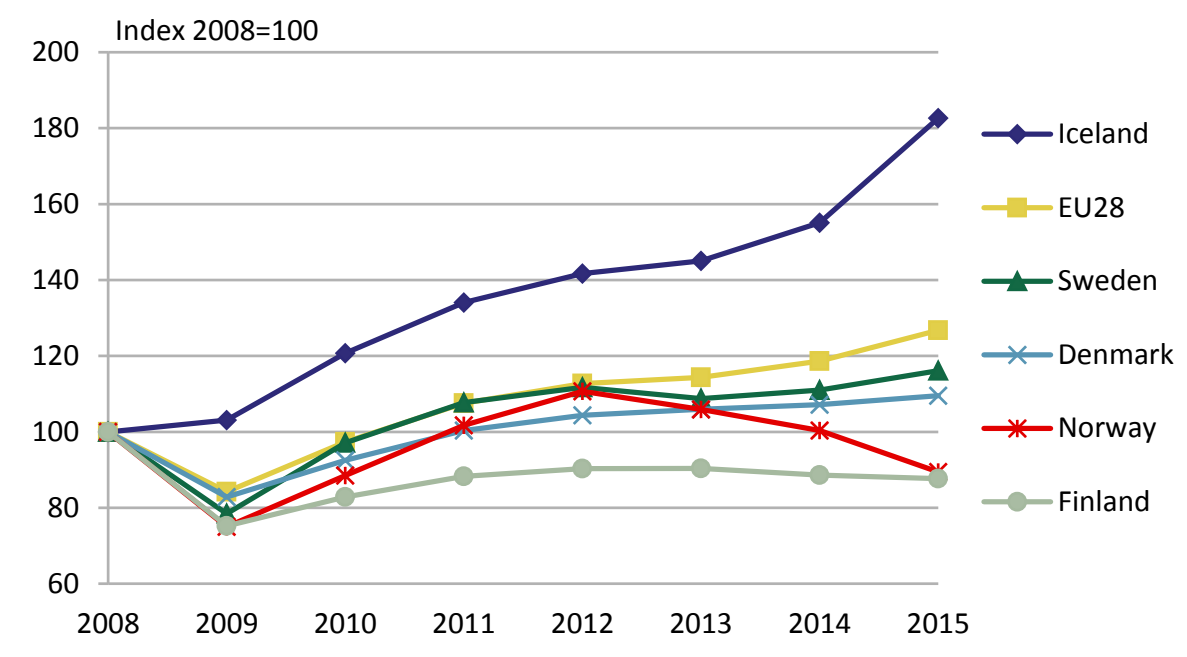

Source: Eurostat (table nama_10_gdp).

In 2015, the value of the Nordic countries' total exports of goods and services was EUR 557 billion (or $8.7 \%$ total EU-28 exports). Sweden was the largest Nordic exporter of goods and services in 2015 followed by Denmark, Norway, Finland and Iceland.

Figure 4: Exports of goods and services. 2015

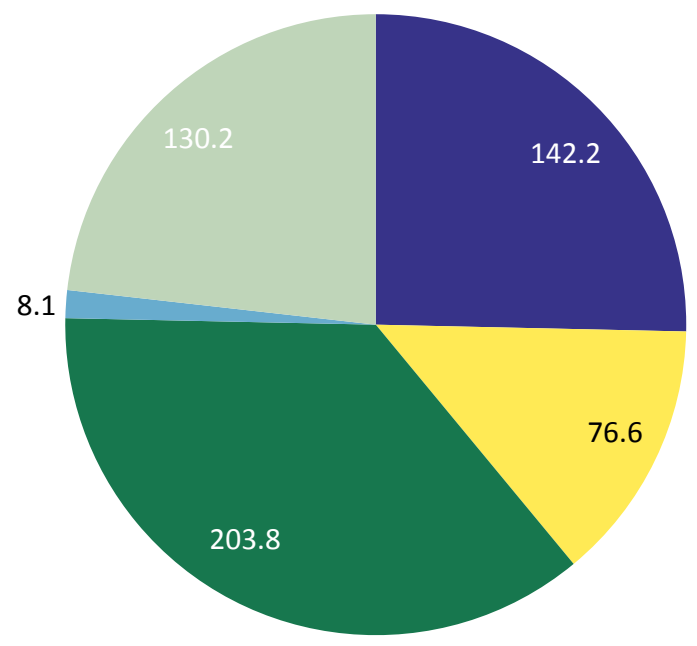

Billion EUR

Source: Eurostat (table nama_10_gdp). 
Exports of services are becoming increasingly important to the Nordic countries. In 2015 services constituted 33 pct. of the total exports from all Nordic countries, up from 27 pct. in 2008. The share of services in total exports has increased considerably in all the Nordic countries, except Denmark. The stagnating share of services in Danish exports are caused by a global overcapacity in sea transport services, Denmark's most important service export, which has led to falling sea transport prices and consequent stagnating export revenues.

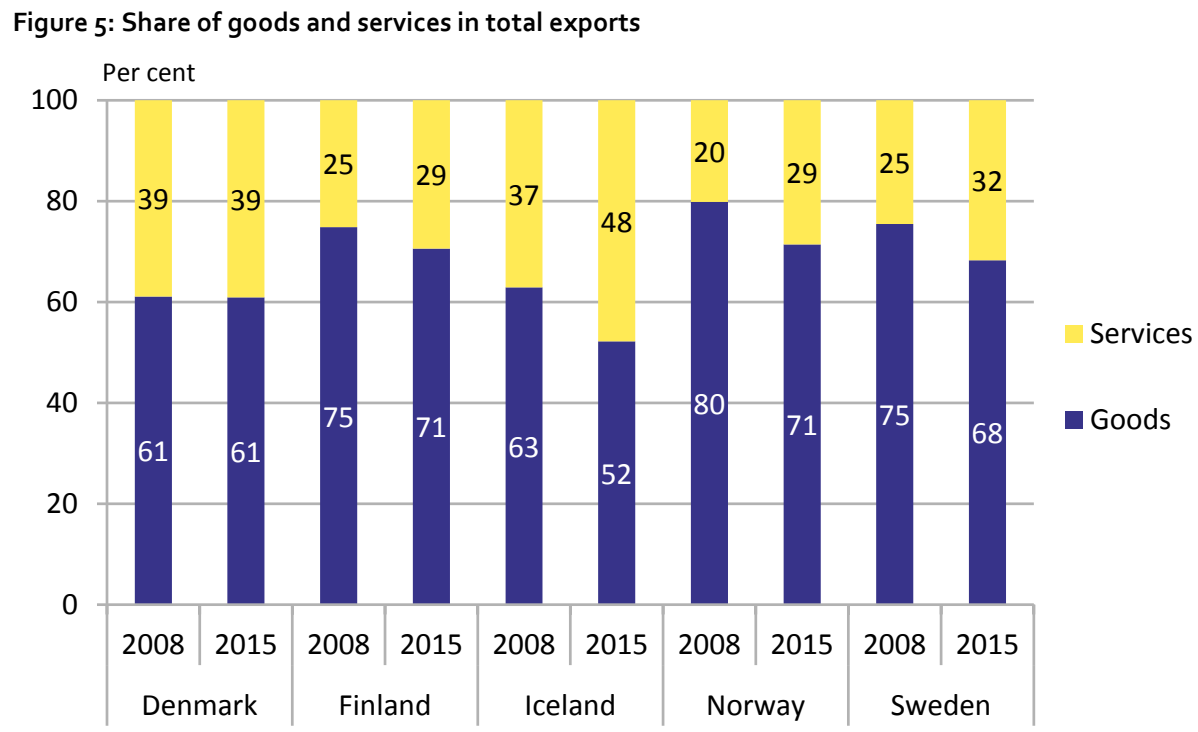

Source: Eurostat (nama_10_gdp).

The report analyses service trade in details in chapter 2 . The remainder of this chapter will focus on the Nordic countries' exports of goods, including their export product strongholds.

The combined value of the Nordic countries' exports of goods was EUR 364 billion in 2015. This was EUR 23 billion lower than in 2008, and EUR 38 billion lower than in 2012, the latest peak year. The shrinking exports in recent years are due to falling revenues from oil exports. Excluding oil the combined Nordic exports was EUR 5.1 billion higher in 2015 than in 2008. Sweden was the largest goods exporter in 2015 , followed by Norway, Denmark, Finland and Iceland. 
Figure 6: Exports of goods

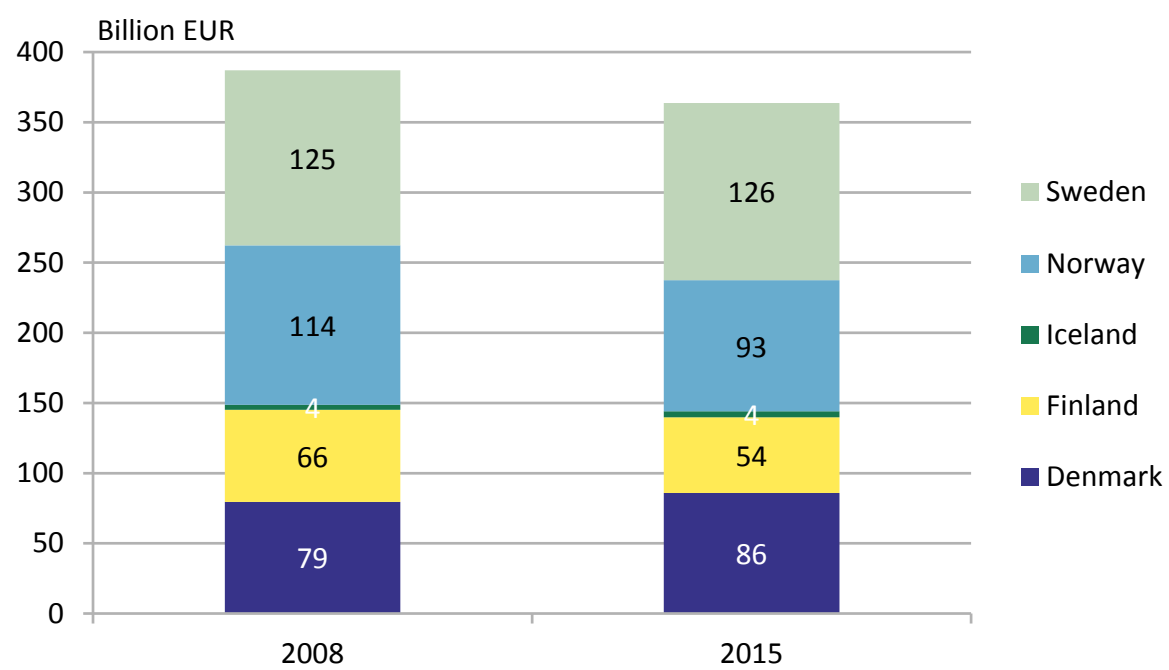

Source: Eurostat EasyComext (table DS-018995 and DS-043227). StatBank Norway (table 08809) for Norwegian 2015 data.

Three Nordic countries - Denmark, Iceland and Sweden - had larger goods exports in 2015 than in 2008 (in current prices). Sweden, however, have seen a recent decline in its goods exports since surpassing its pre-crisis level in 2011 and hovered around the pre-crisis level in 2014 and 2015.

\section{Exchange rates}

Throughout the publication the Eurostat/ECU exchange rates have been used for converting national currencies to EUR, see Annex. Unless otherwise stated reported data is in current prices.

Norway's and Finland's goods exports were lower in 2015 than in 2008. Norway's goods exports surpassed the pre-crisis in 2011 and peaked in 2012, but have dropped sharply since. Finland's exports never fully recovered from the crisis and have been slowly declining since 2012. In comparison, the EU28 countries' combined goods exports have climbed steadily since 2009 (albeit with a slight downward tick in 2014). 


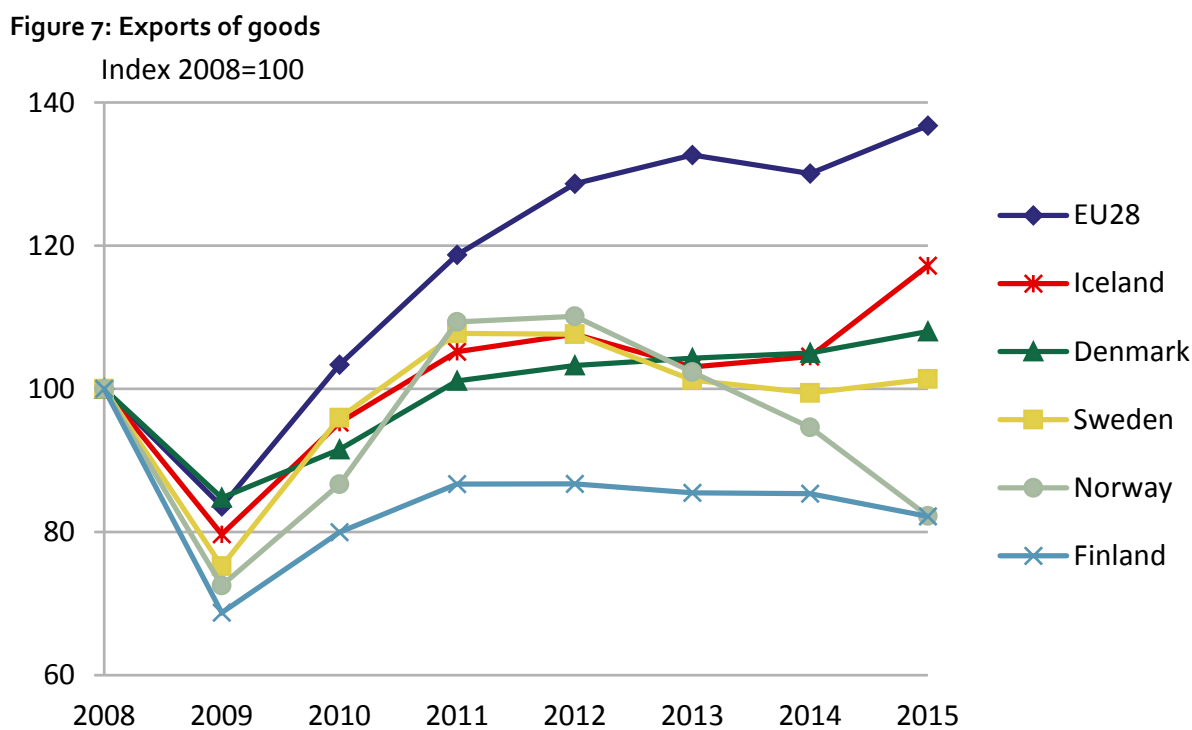

Source: Eurostat EasyComext (table DS-018995 and DS-043227). StatBank Norway (table 08809) for Norwegian 2015 data.

The EU (excluding Nordic EU-members) is by far the largest trade partner for all of the Nordic countries. Norway and Iceland are particularly dependent on the EU as export destination; each sending more than $70 \%$ of total goods exports to a non-Nordic EUcountry. The EU's share of Denmark's goods exports was smaller in 2015 than in 2008, while the EU's share of Finland's goods exports grew as the country's goods exports to the BRIC (and especially neighbouring Russian Federation) fell.

Intra-Nordic goods exports stood at EUR 69.1 billion in 2015. This amounted to $18.2 \%$ of all Nordic goods exports and was slightly less than in 2008 where the corresponding numbers were EUR 71.3 billion and $18.4 \%$. 
Figure 8: Share of exports of goods to selected markets

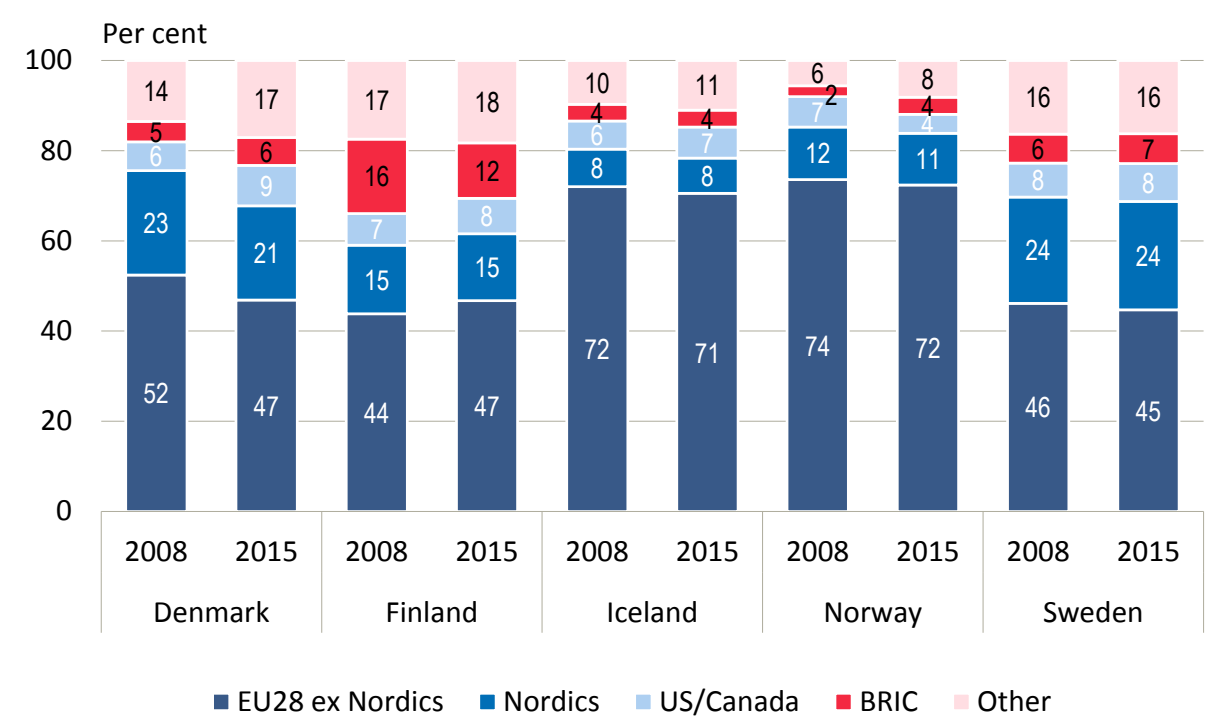

Source: Eurostat EasyComext (table DS-018995 and DS-043227). StatBank Norway (table 08809) for Norwegian 2015 data.

The Nordic region as export destination is most important to Denmark and Sweden and least important to Iceland. In 2015, $24 \%$ of Sweden's and $21 \%$ of Denmark's goods exports (in value terms) were to another Nordic country, while the same was true for only $8 \%$ of Iceland's goods exports. 
Figure 9: Destination share of total national exports of goods

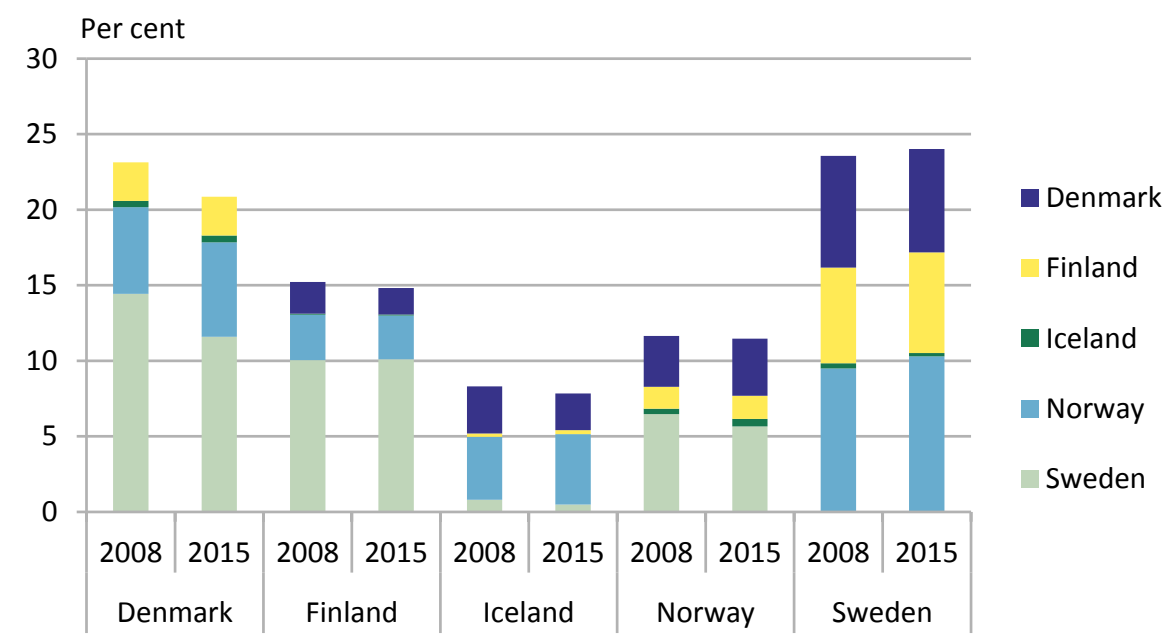

Source: Eurostat EasyComext (table DS-018995 and DS-043227). StatBank Norway (table 08809) for Norwegian 2015 data.

Sweden was the most important export market in the region to Denmark, Finland and Norway, while Norway was the region's most important market to Iceland. To Sweden, Norway is the most important Nordic market followed by Denmark and Finland; and while Norway and Finland have become more important to Sweden as an export destination since 2008, Denmark has become less important. The latter mirrors a similar development in Denmark's goods export: Sweden's share dropped from 2008-2015, while Norway's grew.

\subsection{Nordic export product strongholds}

The Nordic countries have a number of export product strongholds, 4 ie. goods in which the Nordic countries have substantial exports and hold a revealed competitive advantage ${ }^{5}$ on the world market vis-a-vis the EU (including Nordic non-EU-members). The

4 Using the Standard International Trade Classification (SITC) at Division (2-digit) level.

5 A revealed comparative advantage measures a country's exports of a commodity relative to its total exports and to the corresponding export performance of a set of reference countries, here the EU. A comparative advantage is revealed if this is larger than 1. For example, EU's exports of Medicinal and Pharmaceutical products in 2015 represented $6.2 \%$ of EU's total exports. 
development of selected strongholds from 2008 to 2015 are described below and summarised in table 1.

Petroleum and petroleum products is the most important Nordic export product group (in value terms) accounting for EUR 43 billion or $12 \%$ of total Nordic goods exports in 2015. While this product group is important to all Nordic countries (except Iceland), it is vital to Norway. As mentioned above, falling prices in recent years have caused a dramatic fall in Norway's overall goods exports; and within one year from 2014 to 2015 the value of the country's exports of Petroleum and petroleum products fell from 41 to EUR 26 billion.

Fish is a traditional Nordic stronghold and represents the product group with the Nordics' second largest revealed comparative advantage vis-á-vis the EU. In 2015, exports totalled EUR 16 billion, up from 10 billion in 2008. It is Iceland's second largest and Norway's third largest export group; and all the Nordics except Finland have a revealed comparative advantage in Fish.

Paper and paperboard is another traditional Nordic stronghold with combined Nordic exports of EUR 16 billion in 2015 - one billion EUR lower than in 2008. It is Finland's largest and Sweden's third largest export product group and the two are the only Nordic countries with revealed comparative advantages in the product group.

Hides, skin and furskins is the Nordic stronghold with the third highest revealed comparative advantage vis-áa-vis the EU. However, with combined Nordic exports of only EUR 2.3 billion in 2015, it is a niche industry making-up less than $1 \%$ of all Nordic exports.

Medicinal and Pharmaceutical products is the third largest Nordic export product group and is becoming increasingly important; between 2008 and 2015, the Nordics combined exports of this product group grew from EUR 13 billion to 21 billion. It is Denmark's largest export product group (almost EUR 12 billion in 2015) and Sweden's fourth largest (almost EUR 8 billion). Despite its importance, Denmark is the only Nordic country to hold a revealed comparative advantage vis-a-vis the EU in the product group.

Power-generating machinery and equipment was the ninth largest export for the Nordic countries as a group in 2015 with combined exports of EUR 13.4 billion, up from EUR 11.8 billion in 2008. It was Denmark's third largest export in 2015; and of the Nordics only Iceland and Norway do not have a revealed comparative advantage in this product group.

Road vehicles are Sweden's largest export valued at EUR 14.6 billion in 2015 - a slight decrease relative to 2008 . None of the other Nordic countries have large scale production of road vehicles, yet they are Finland's seventh and Denmark's 14th largest export.

Denmark's exports of the same commodity group represented $13.4 \%$ of Denmark's total exports. And since $13.4 / 6.2$ equals 2.2 , Denmark has a revealed comparative advantage vis-à-vis the EU in Medicinal and Pharmaceutical products. 
Sweden, though, is the only Nordic country to hold a relative comparative advantage in the product group.

Non-ferrous metals, such as aluminium, are Iceland's most important export and constituted $40 \%$ of its total goods exports in 2015 . The product group is Norway's fourth largest and Finland's ninth largest. With combined Nordic exports of EUR 11.4 billion in 2015 (down from 12.3 billion in 2008) all Nordic countries but Denmark have a revealed comparative advantage in this product group.

Telecommunication equipment has for several decades been a Nordic stronghold. In 2008, it was Finland's most important export and Sweden's fourth largest; and overall it was the Nordics' fifth largest. Since then Nordic exports of telecommunication equipment have suffered a dramatic set-back. In value terms, it more than halved from EUR 19.7 billion in 2008 to 9.7 billion in 2015. Finland no longer have a strong revealed comparative advantage in the product group as its telecommunication exports fell from EUR 9 billion in 2008 to just 0.7 billion in 2015. Sweden is now the only Nordic country with a revealed comparative advantage in telecommunications.

\begin{tabular}{|c|c|c|c|c|c|}
\hline & Denmark & Finland & Iceland & Norway & Sweden \\
\hline $\begin{array}{l}\text { Petroleum, } \\
\text { petroleum products }\end{array}$ & Large loss & Loss & & $\begin{array}{l}\text { Key stronghold, } \\
\text { considerable loss }\end{array}$ & Loss \\
\hline Fish & Gain & & Small gain & $\begin{array}{l}\text { Key stronghold, } \\
\text { Large gain }\end{array}$ & Gain \\
\hline Paper, paperboard & & $\begin{array}{l}\text { Key stronghold, small } \\
\text { loss }\end{array}$ & & & Gain \\
\hline $\begin{array}{l}\text { Raw hides, skins, } \\
\text { furskins }\end{array}$ & Considerable gain & Small gain & & & \\
\hline $\begin{array}{l}\text { Medicinal, pharmaceuti- } \\
\text { cal products }\end{array}$ & $\begin{array}{l}\text { Key stronghold, } \\
\text { considerable gain }\end{array}$ & & & & \\
\hline $\begin{array}{l}\text { Power-generating ma- } \\
\text { chinery and equipment }\end{array}$ & Gain & Small loss & & & Gain \\
\hline Road vehicles & & & & & Small loss \\
\hline Non-ferrous metals & & Small loss & Small gain & Large gain & Stable \\
\hline Telecommunication & & $\begin{array}{l}\text { Dramatic loss, no longer } \\
\text { a key stronghold }\end{array}$ & & & Loss \\
\hline
\end{tabular}

Source: Eurostat EasyComext (table DS-018995 and DS-043227). StatBank Norway (table o8809) for Norwegian 2015 data. 



\section{International trade in services in the Nordic countries}

\section{Main Findings}

- Sweden is the largest Nordic service exporter with total exports of services of EUR 56.6 billion in 2014. Denmark exported slightly less with service exports amounting to EUR 54.9 billion. The other Nordic countries exported significantly less, as Norway exported EUR 37.8 billion, Finland EUR 21.2 billion, and Iceland EUR 3.2 billion.

- Between 2010-2014 the development in exports of services has differed among the Nordic countries. Iceland experienced an increase in exports of $42 \%$. In the same period the service exports of Sweden grew 38\%, Norway 20\%, Denmark 18\%, and Finland 1\%. In comparison, total EU 28 exports of services rose $29 \%$.

- Trade between the Nordic countries is considerable. On average, about one-fifth of the countries' exports of services consist of trade in services with other Nordic countries. Service exports from the Nordic countries are concentrated on a few services.

- Transport services is the most important service category in Nordic exports, accounting for $32.4 \%$ of total Nordic services exports in 2014. Nordic exports of transport services accounted for as much as $17.9 \%$ of EU 28 transport service exports in 2014. Other strongholds include Telecommunication and Construction services.

- In all Nordic countries more than half of service exports are carried out by domestically controlled enterprises.

In all the Nordic countries, services constitute a large and growing part of Nordic countries' global trade. Unfortunately, we still know relatively little about trade in services in general and about the enterprises that engage in service trade in particular. This is primarily due to the lack of data on trade in services compared with trade in goods. Whereas trade in goods statistics are based on near-complete customs data (and equally near-complete intra-EU survey data), statistics on trade in services are based on smaller sample surveys. In addition, trade in services is collected using only about 60 different service categories compared to the more than 9.000 goods categories. Furthermore, whereas the methodological approach to international trade in goods statistics is harmonised across most countries, different methodological approaches are applied in relation to services trade - even between comparatively similar economies such as the Nordic countries. 
Notwithstanding these methodological challenges, this chapter will explore the Nordic strongholds in international trade in services, both on the geographical level and on the type of services traded (e.g. transport services, ICT-services, financial services, etc.). More importantly, the chapter will provide new and unique insights into the Nordic enterprises behind the trade in services by linking micro data from the services trade surveys with statistical business registers.

A note on data availability/nature of the analysis on enterprises engaged in service trade: Tables in sections named "Exporters of services" are depicting percentage shares of the reported trade instead of the absolute values. The reason for this is that the services trade surveys' sample sizes are not fully covering the entire population; therefore the level of non-observed (and thus estimated) trade is high and varying among the different countries. The designs of the surveys are typically optimized with respect to service categories and not necessarily enterprise characteristics such as business activity and ownership, and therefore the estimated trade cannot be allocated robustly to the enterprise level. Furthermore, some services are collected from other sources where a link between the statistical business registers cannot be established. Without the non-observed trade and trade from other sources, the total trade from reporting enterprises do not represent all trade.

An inherent weakness of this approach is that we cannot meaningfully compare shares of different size-classes (e.g. large vs. SMEs in manufacturing), since this would bias the results in favour of large enterprises (because the majority of the non-observed trade tends to be from smaller enterprises).

\subsection{The Nordic countries}

\subsubsection{Part I. Trade patterns and market trends}

Over the recent decades, trade in services has grown more quickly than trade in goods. The same pattern appears when looking at the Nordic countries. Consequently, services account for a growing share of the world trade of the Nordic countries.

The Nordic countries are small, open economies and thus export-depending countries. In 2014, the Nordic countries exported services for nearly EUR 173.7 billion, corresponding to $10.3 \%$ of EU28 exports of services globally.

Sweden is the largest Nordic exporter on the world market with total exports of services of EUR 56.6 billion in 2014 (or $3.4 \%$ of EU28 exports). Denmark exported 
slightly less with service exports amounting to EUR 54.9 billion (or 3.3\%). The other Nordic countries exported significantly less, as Norway exported EUR 37.8 billion (2.2\%), Finland EUR 21.2 billion (1.3\%), and Iceland EUR 3.2 billion (0.2\%), cf. figure $10 .{ }^{6}$

When looking at service exports as share of GDP, the picture slightly changes, as Iceland is the most service exports oriented economy with a share of $25 \%$ in 2014. Denmark is the second most service exports oriented economy as exports of services constituted $21 \%$ of GDP followed by Sweden (13\%), Norway (10\%), and Finland (10\%). In comparison, the EU28 exports of services constituted $12 \%$ of EU 28 GDP.

In the period from 2010 to 2014 the development in exports of services has differed among the Nordic countries, cf. figure 11.

Iceland has had the steepest growth in service exports. Iceland, which is by far the smallest exporter among the Nordic countries, saw an increase in exports of $42 \%$ within the four year period.

Figure 10: Nordic exports of services. 2014

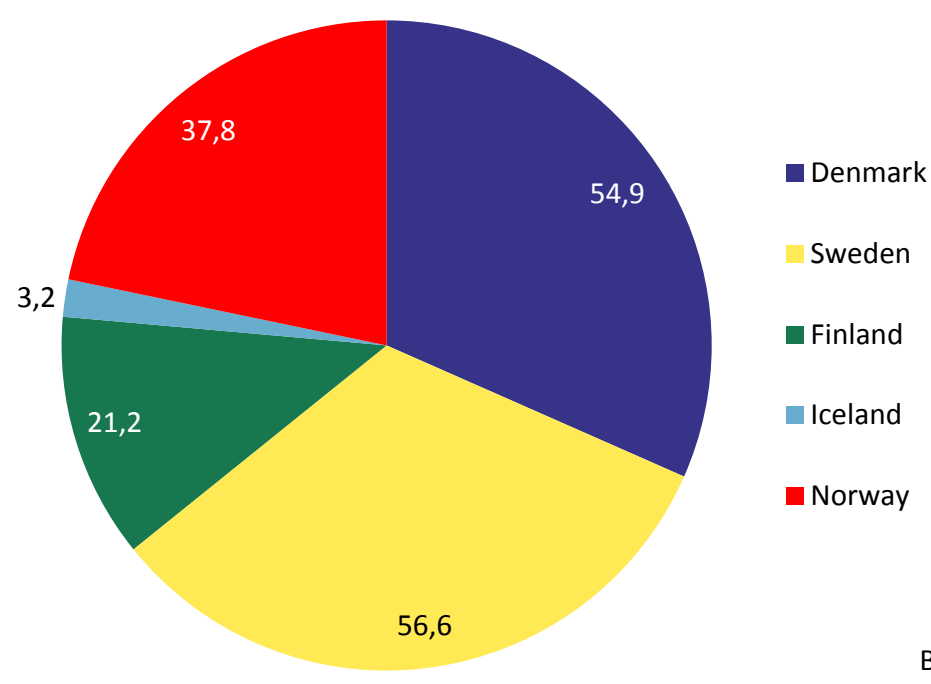

Billion EUR

Source: See Annex 1.3

An increase of a similar magnitude was observed in Sweden, where service exports grew $38 \%$.

\footnotetext{
${ }^{6}$ Even though Norway and Iceland are not part of the EU, exports are compared to the EU in order to make comparisons across the Nordic countries.
} 
Figure 11: Development in exports of services

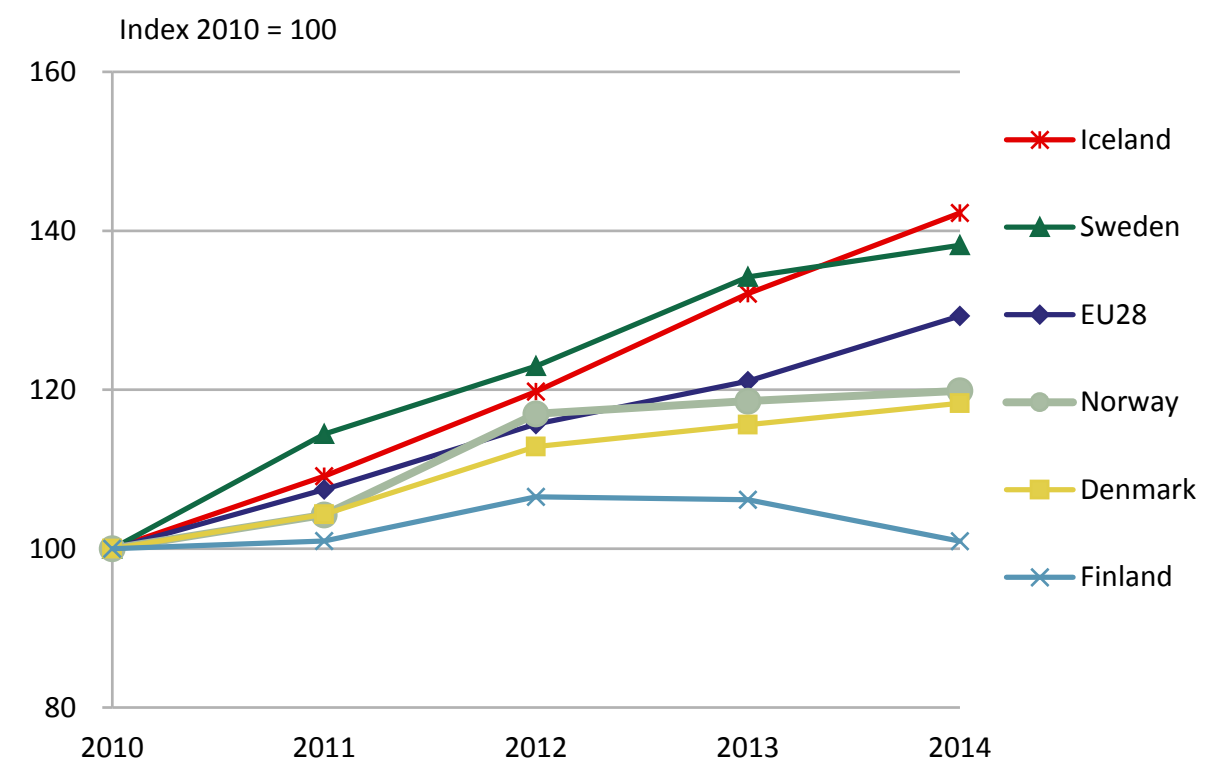

Source: See Annex 1.3.

Norway experienced an increase of $20 \%$, Denmark $18 \%$, and Finland $1 \%$. Finland's close to zero growth is due to a fall in exports during the last two years of the period.

Compared to the development in EU's services trade from 2010 to 2014, Iceland and Sweden are the only Nordic countries that did better than EU28. EU28 exports of services rose $29 \%$ in the period, which was also higher than the increase in total Nordic exports of services that rose $22 \%$. 
Figure 12: Share of EU28 exports of services

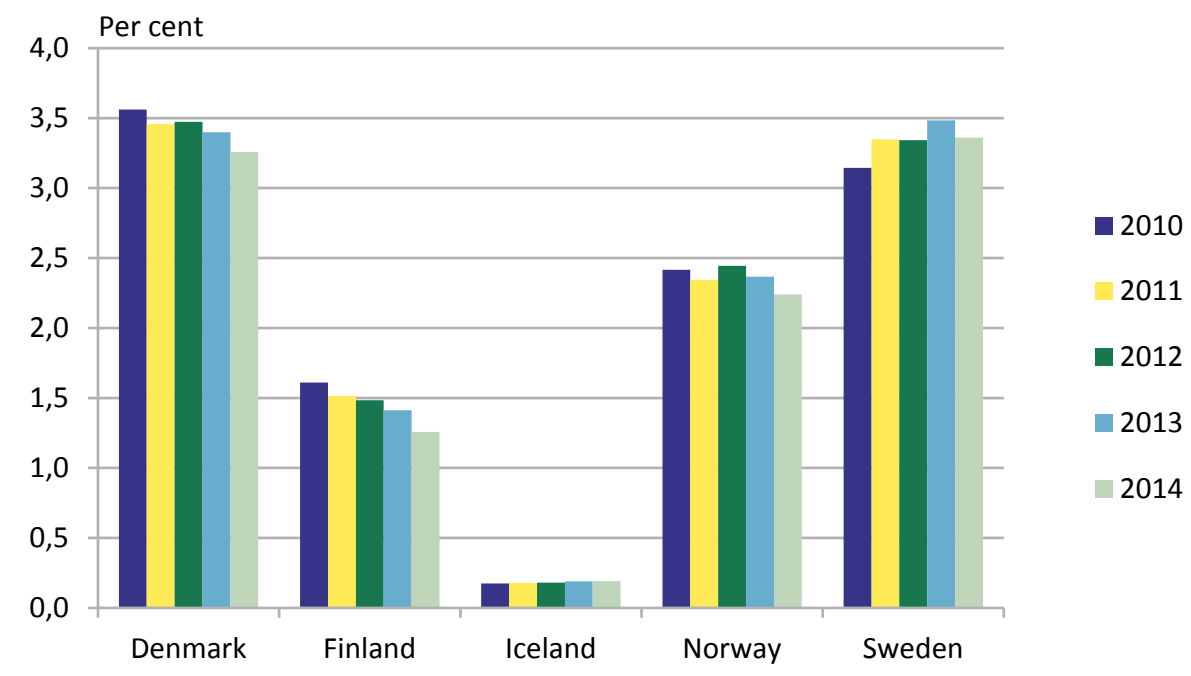

Source: See Annex 1.3

The development described above has had an effect on the Nordic countries' share of total EU28 service exports. In 2010 Denmark was the largest Nordic exporter of services, and represented $3.6 \%$ of EU28's total exports of services. In 2014 this share had dropped to $3.3 \%$. In the meantime Sweden increased its share from $3.1 \%$ to $3.4 \%$, making it the Nordic country with the highest share of EU28 service exports in 2014, cf. figure 12.

\subsubsection{Market trends}

The Nordic countries are in general more global oriented with regard to exports in services compared to exports in goods. On average, only half of total Nordic exports of services are targeting the neighbouring markets - EU and the Nordics. For goods exports this share is much higher, cf. figure 8 and figure 13 .

Norway is by far the most EU-oriented country. In $2014,66.7 \%$ of total Norwegian service exports went to the EU28, followed by Finland (52.7\%), Sweden (52.0\%), Denmark (44.7\%) and Iceland (43.9\%), cf. figure 13. 
Figure 13: Market shares of total national exports of services. 2014

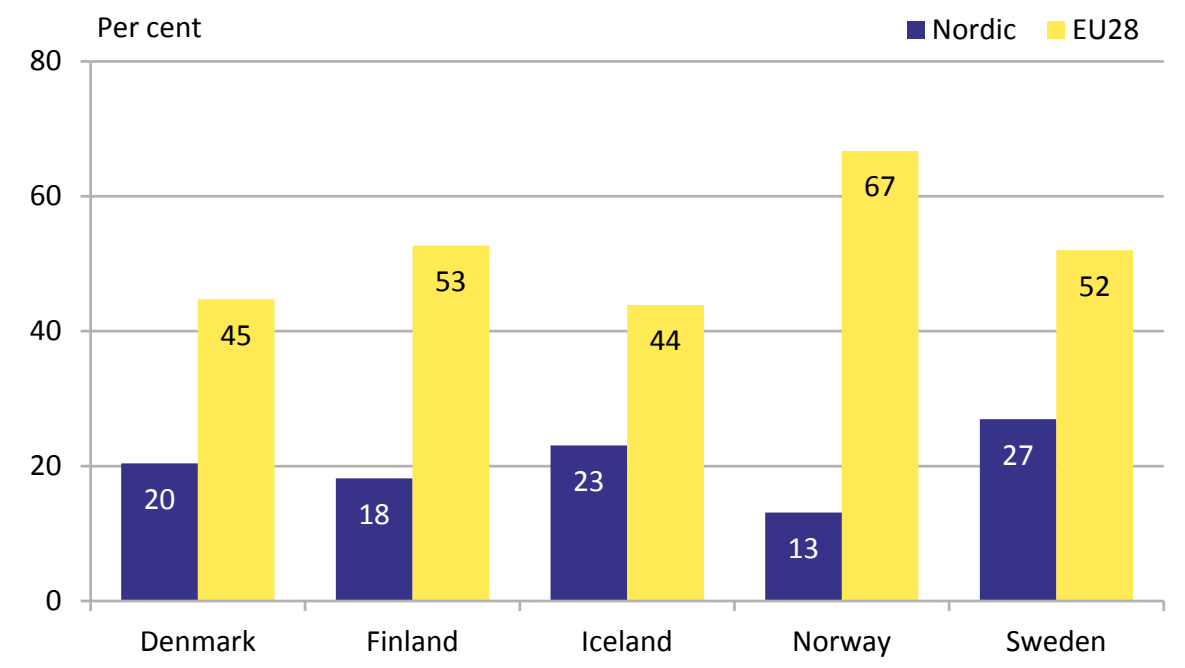

Note: Data on Iceland cover 2013.

Source: See Annex 1.3.

Trade between the Nordic countries is quite considerable. On average, about one-fifth of the countries' exports consist of trade in services with other Nordic nations. However, the extensiveness of Nordic trade varies greatly among the countries. Sweden is the most Nordic-oriented country in this regard as $27.0 \%$ of Swedish exports went to its Nordic neighbours in 2014. Nordic countries accounted for $23.1 \%$ of Icelandic service exports, making Iceland the second most Nordic-oriented, followed by Denmark (20.4\%), Finland (18.2\%), and Norway (13.1\%).

\subsubsection{Strongholds}

A common characteristic in service exports from the Nordic countries is a concentration on a few services, typically dominated by a few large export-oriented enterprises. Denmark has the least diversified export pattern, as the largest service category, Transport services, accounted for more than $60 \%$ of total Danish service exports in 2014 .

Transport services is also the most important service category in Nordic exports, accounting for EUR 56.4 billion, equivalent to $32.4 \%$ of total Nordic service exports in 2014 . 
Sweden and Finland are the only Nordic countries where this service category did not account for the largest share of exports in services in 2014. Nordic exports of transport services accounted for as much as $17.9 \%$ of EU28 transport service exports in 2014.

Figure 14: National share of EU28 exports of transport services. 2014

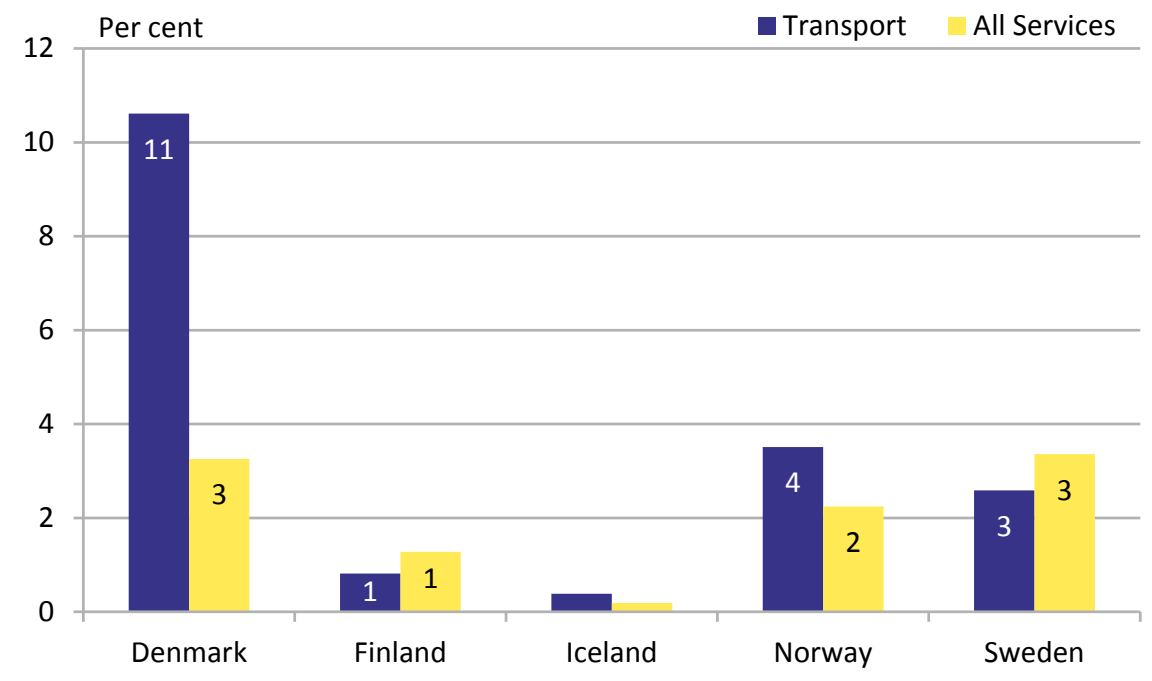

Source: See Annex 1.3.

Another traditional Nordic stronghold is Telecommunication, computer, and information services - which is among the main export categories of Sweden and Finland. The service category constituted the second largest share of Nordic exports in 2014 amounting to $16.1 \%$ of Nordic service exports.

The Nordic share of EU28 exports of telecommunication services accounted for 13.3\% in 2014. In absolute terms, exports from Norway in this service area is similar to the level exported from Finland, however, compared to total national service exports it constitutes a smaller share. Sweden's exports of ICT-services (telecommunication, computer, and information services) totalled EUR 11.9 billion in 2014 corresponding to 5.6 of EU28 exports of ICT-services, cf. figure 15 .

Another Nordic stronghold is construction services. Nordic exports of construction services totalled "merely" EUR 4.4 billion or 2.6\% of total Nordic exports in 2014. Moreover, this service category is not in the top 3 in any of the Nordic countries. However, compared to EU28 it was the second-most important exports category, as Nordic exports constituted $17.3 \%$ of total EU 28 exports of construction services in 2014 . 
Figure 15: National share of EU28 exports of Telecommunication, computer, and information services. 2014

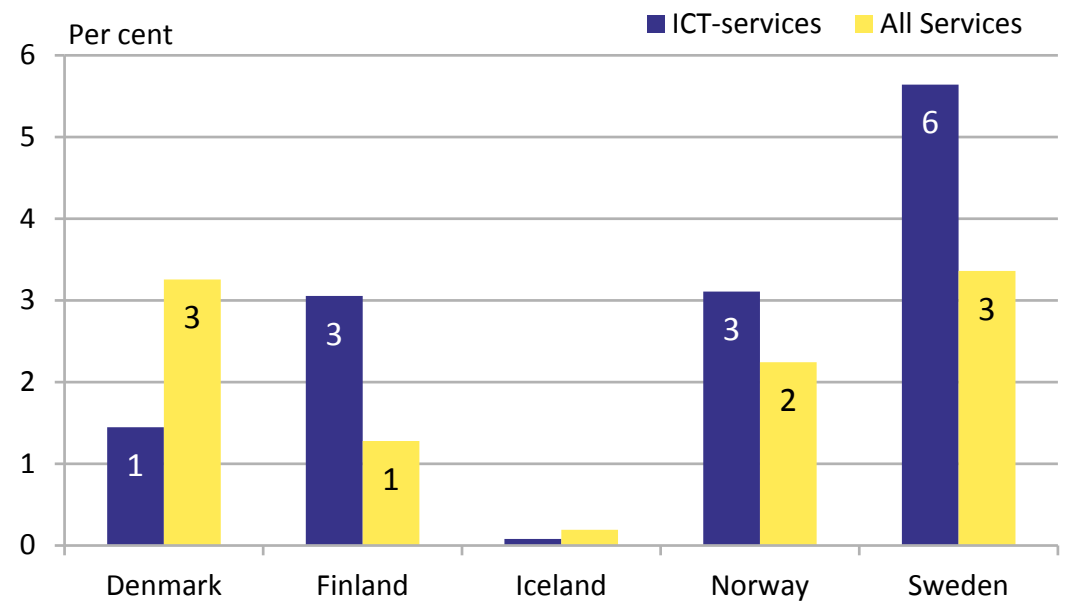

Source: See Annex 1.3.

Denmark, and to a lesser extent Finland, exports a relatively high amount of these kinds of services, cf. figure 16. In 2014, Danish construction services accounted for $10.5 \%$ of total EU28 exports of construction services to the global market.

Figure 16: National share of EU28 exports of construction services. 2014

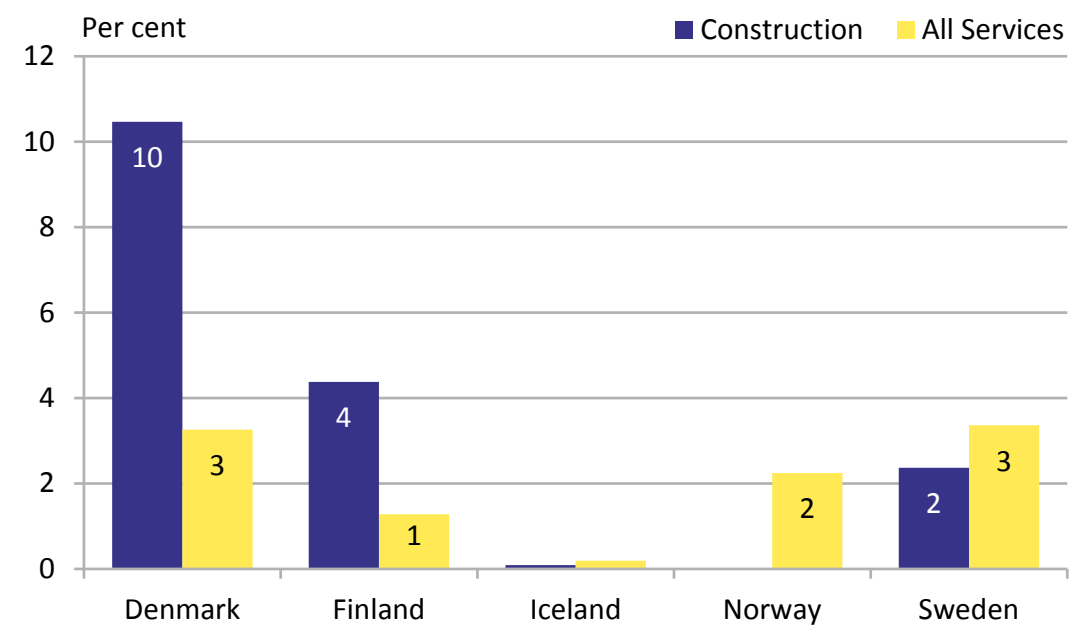

Note: Data on construction services for Norway not available.

Source: See Annex 1.3. 


\subsubsection{Part II. Exporters of services ${ }^{7,8}$}

Even though the data do not support exact conclusions on the difference between the trade of large enterprises and SMEs (as described in the introduction), large enterprises appear to dominate trade in services for all Nordic countries, except from Norway. In the period 2010 to 2014 the development in how much the large enterprises constitute of total service exports have differed among the Nordic countries, cf. figure 17.

The most noteworthy development is in Finland where the large enterprises account for a much smaller share of Finnish service exports in 2014 compared to 2010 . This may be seen as a consequence of the changes in the Finnish ICT industry in recent years. ${ }^{9}$

\section{Figure 17: Growth in large enterprises' share of exports in services. 2010-2014}

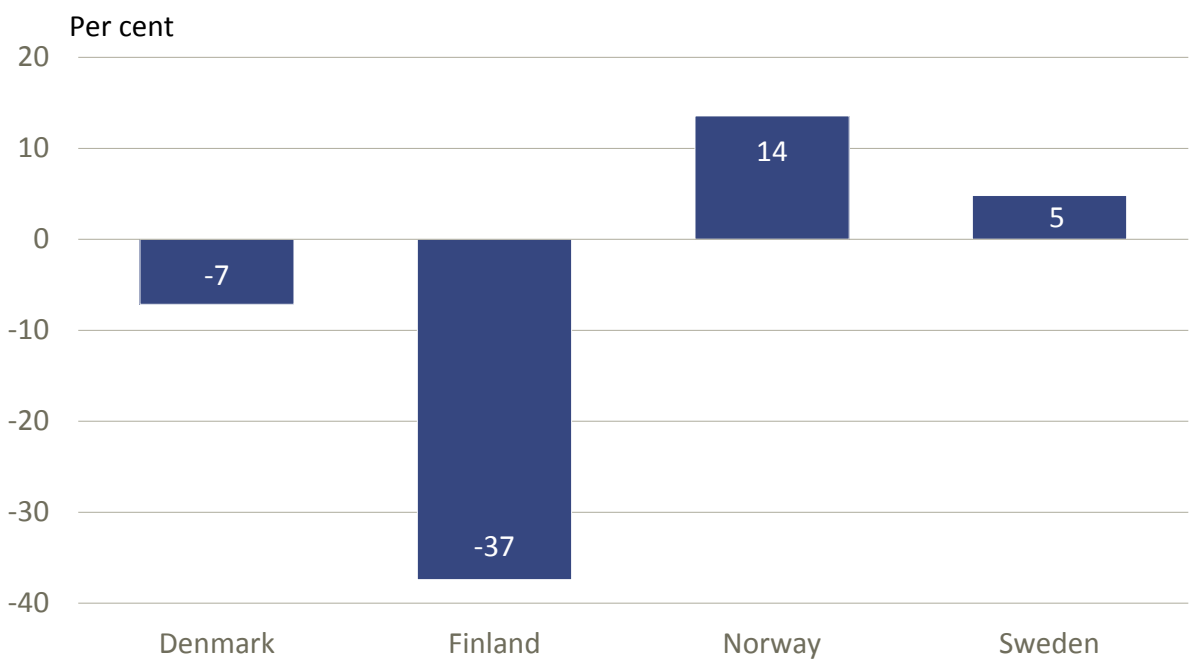

Source: National services trade surveys linked with statistical business registers. See Annex 1.3 for a more detailed description.

In all Nordic countries more than half of service exports are carried out by domestically controlled enterprises. However, the export patterns differ across the countries, cf. figure $18 .{ }^{10}$ One of the differences is how much national MNEs account for of total exports,

\footnotetext{
7 Note that the conclusions in this section are based on data with certain limitations. For more detailed information see the introduction to this chapter and annex 1.3.

${ }^{8}$ Unfortunately, it has not been possible to get data on Iceland to this part of the chapter.

9 ICT is an abbreviation for Information and Communications Technology.

${ }^{10}$ Type of ownership is defined by nationality of ownership - being domestically or foreign owned - and for domestically owned enterprises their presence abroad by having foreign affiliates. For a more detailed description of ownership see chapter 5 .
} 
which is measured by the share of exports carried out by domestically owned enterprises with foreign affiliates.

Most service exports from Denmark are exported by domestically owned enterprises with foreign affiliates (national MNEs) (67\%). In Norway this type of enterprises account for $32 \%$ of exports, in Finland $23 \%$, and in Sweden only $10 \%$. More than half of total Swedish exports in services are conducted by domestically owned enterprises without foreign affiliates. In Denmark the share of exports from this category is $13 \%$. In Norway domestically owned enterprises with foreign affiliates account for approximately the same share of exports as domestically owned enterprises without foreign affiliates. In Finland foreign owned enterprises account for approximately the same share of exports as domestically owned enterprises without foreign affiliates.

The share of exports carried out by foreign owned enterprises varies across the Nordic countries. In Finland the share is $42 \%$, whereas in Sweden it is $36 \%$, in Norway $30 \%$, and in Denmark 21\%.

Figure 18: Exports of services. By ownership. 2014

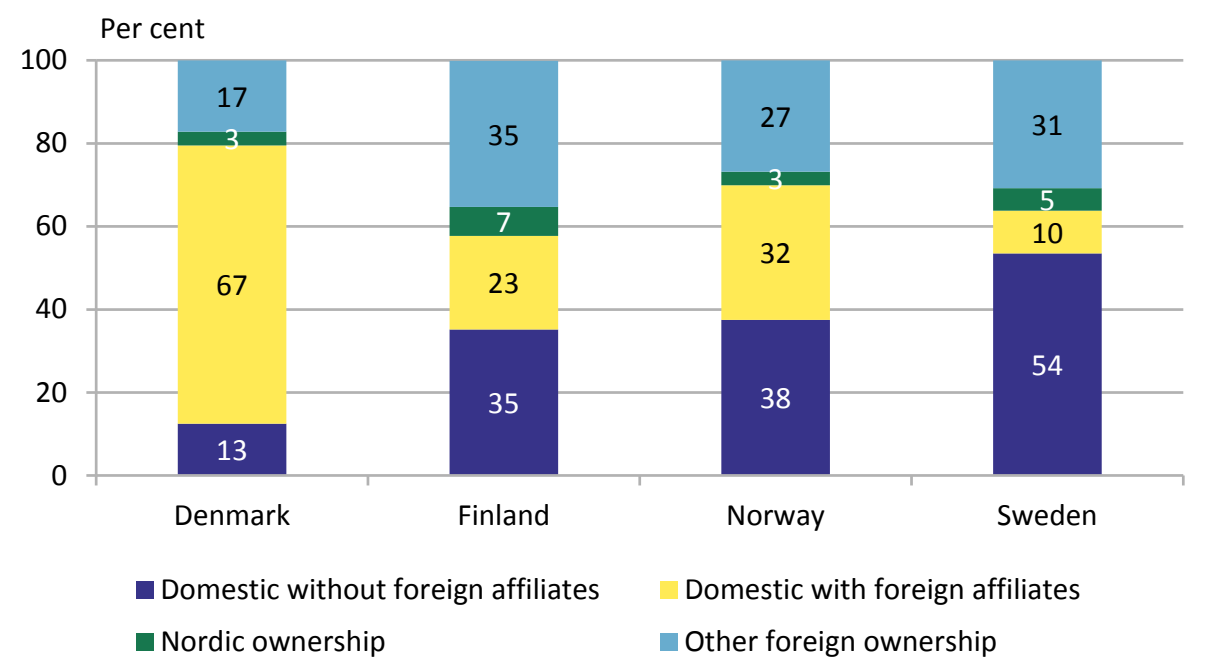

Source: National services trade surveys linked with statistical business registers. See Annex 1.3 for a more detailed description.

The differences in ownership patterns should be seen in the context of national strongholds. The stronghold of both Denmark and Norway is Transport services, especially seatransport. It is mainly exported by domestically owned companies. However, whereas in Denmark most transport services are exported by enterprises with foreign affiliates, 
exports of Norwegian transport services are almost equally divided between enterprises with affiliates abroad and enterprises with no affiliates abroad.

One of the strongholds of Sweden and Finland is Telecommunication, computer, and information services. In Sweden these are mainly exported by domestically owned enterprises, but in Finland, there has been a change in recent years, and the foreign owned enterprises are now the largest exporters within the industry.

In Sweden and Finland domestically owned enterprises without affiliates abroad are more world seeking than domestically owned enterprises that do have affiliates abroad, cf. figure 19. The opposite pattern is present in Denmark and Norway. As before, the explanation may be found in differences among the countries in national strongholds.

Figure 19: Exports of services. By ownership and export destination. 2014

Nordic countries EU countries other than Nordics $\quad$ Rest of the world

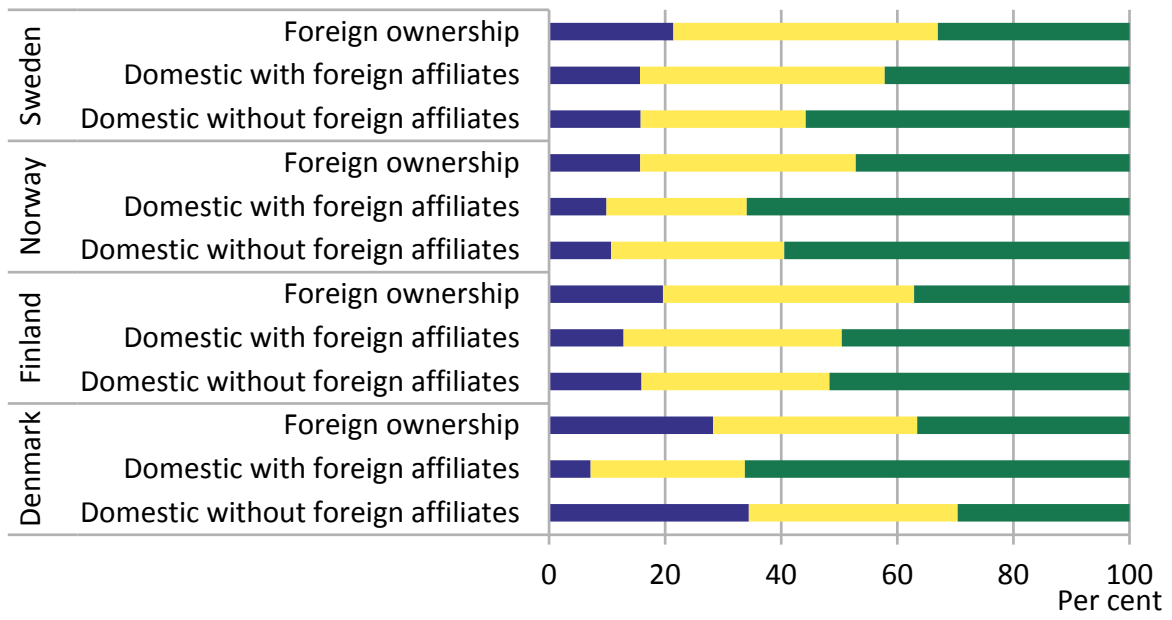

Source: National services trade surveys linked with statistical business registers. See Annex 1.3 for a more detailed description.

Export patterns seem to depend on enterprise size. Across all Nordic countries large enterprises export a big share to distant markets, cf. figure 20. In all Nordic countries, except from Norway, exports carried out by SMEs are mostly sold to the neighbouring countries. However, Nordic SMEs belonging to a group generally have substantially larger exports to the EU countries and are generally exporting more to the neighbouring countries. 
Figure 20: Exports of services. By enterprise size and export destination. 2014

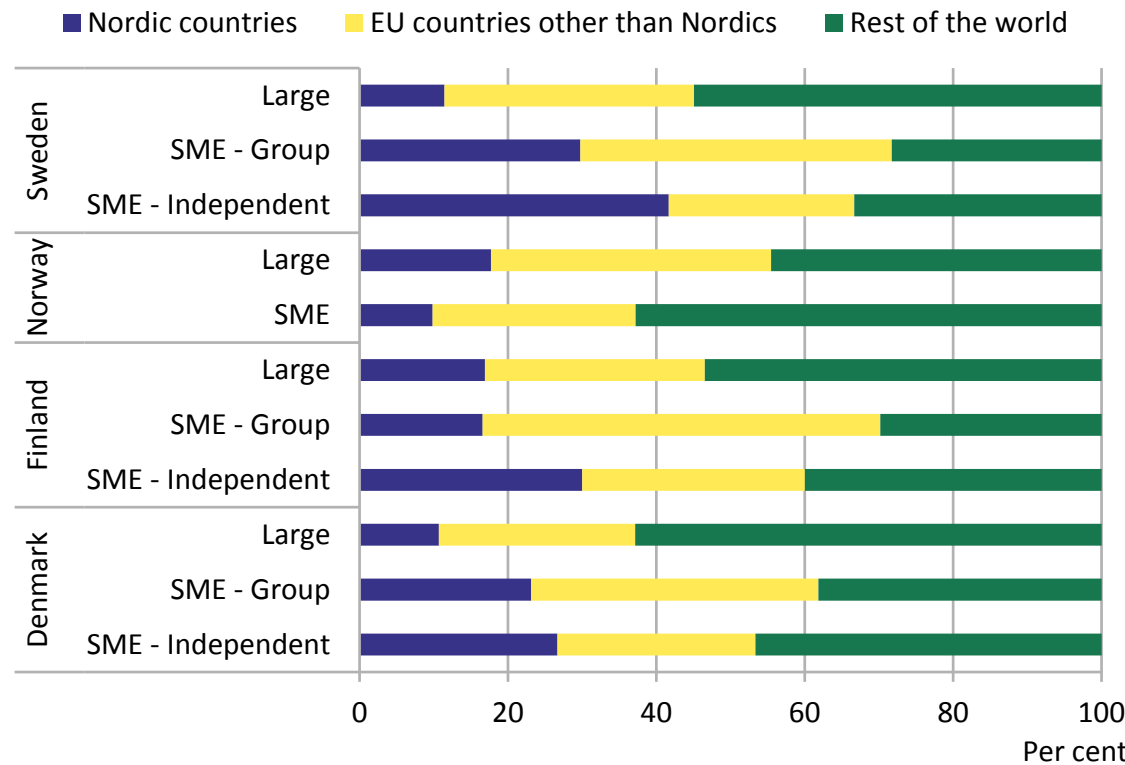

Note: SME-split not available for Norway.

Source: National services trade surveys linked with statistical business registers. See Annex 1.3 for a more detailed description.

\subsection{Denmark}

\subsubsection{Part I. Trade patterns and market trends}

Trade in services plays an important part in Danish international trade. With EUR 54.9 billion in exports of services, Denmark was the second-largest exporting economy in the Nordic region in 2014 with regards to service trade after Sweden. Danish exports of services accounted for $21 \%$ of GDP in 2014 .

From 2010 to 2014, Danish service exports increased 18.3\%, as figure 21 illustrates. Imports of services have been at a lower level during the entire period. 
Figure 21: Development in trade of services

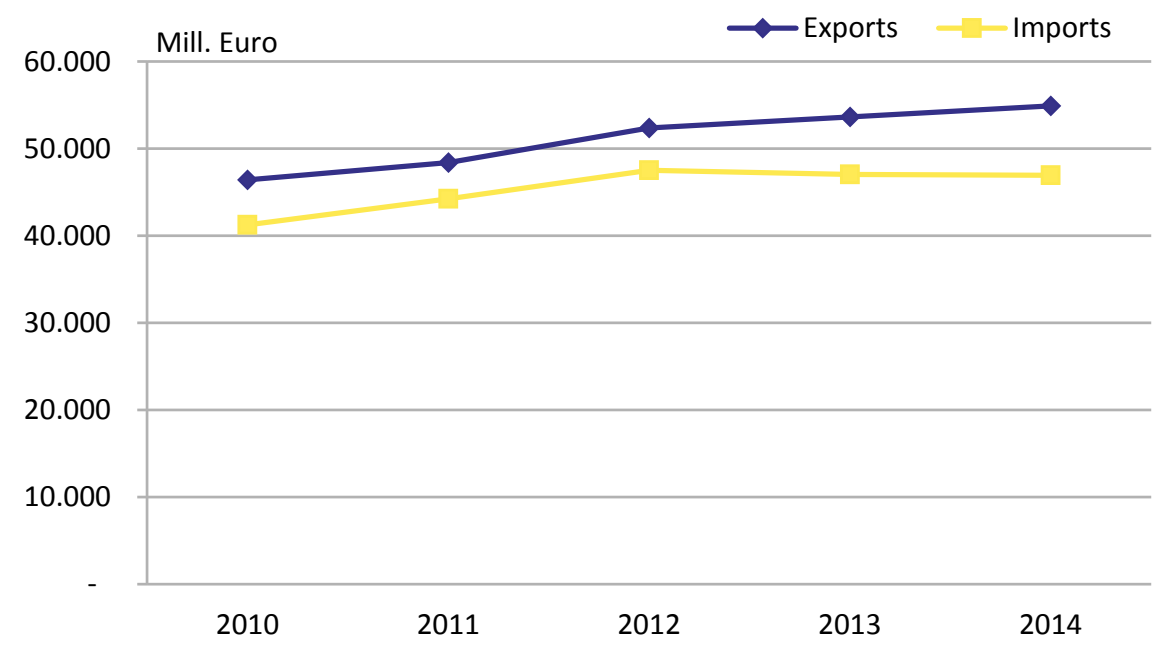

Source: See Annex 1.3

As mentioned, Danish exports increased by $18 \%$ in the period 2010 to 2014 . Danish exporters lost ground, however, when measured against EU28 exports, which increased $29 \%$, cf. figure 22. As a result, the Danish share of $3.3 \%$ of EU28 exports in 2014 was lower than the 2010 share of $3.6 \%$.

Figure 22: Development in trade of services

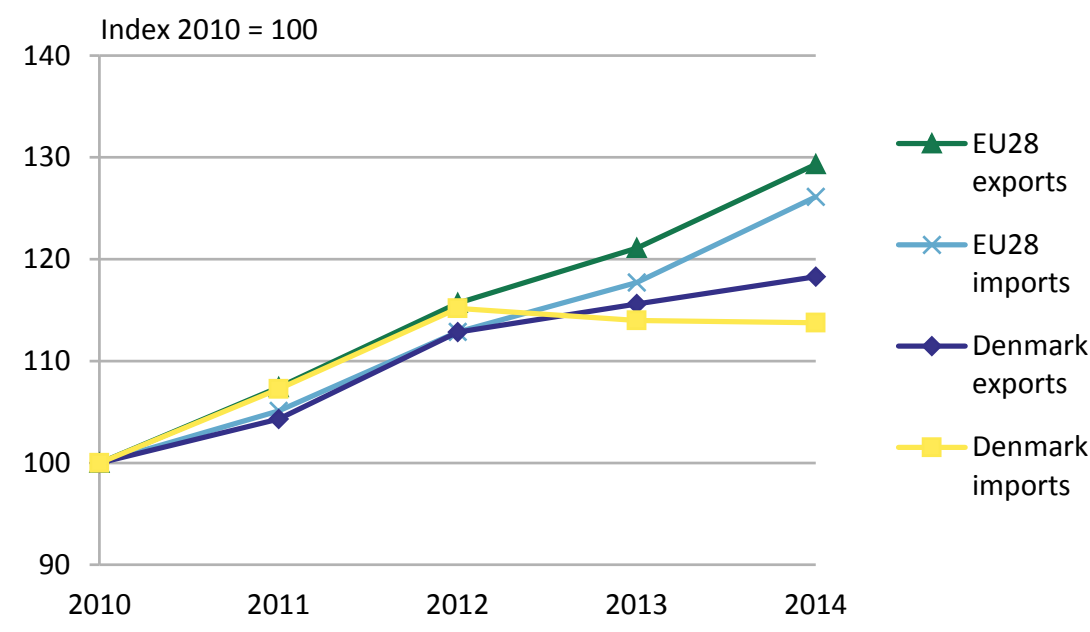

Source: See Annex 1.3 
In 2010 Denmark was the largest Nordic exporter of services. As Sweden experienced a stronger growth in service exports between 2010 and 2014, Sweden overtook the position as being the Nordic country with the highest share of $\mathrm{EU}_{2} 8$ service exports in 2014 .

\subsubsection{Market trends}

Danish exports of services are dominated by sea transport, which is characterised by being globally oriented; consequently EU 28 is less important to Danish service exports than to the service exports of other Nordic countries cf. figure 23.

In absolute terms, Danish exports to $\mathrm{EU}_{2} 8$ have increased in the period from 2010 to 2014 , from EUR 21.1 to 24.6 billion. Sweden and Germany were the most important EU export destinations in 2014, each accounting for $10 \%$ of total services export.

Globally, United States was the largest single-country market for Danish exports in 2014 , accounting for $12 \%$ of exports in services.

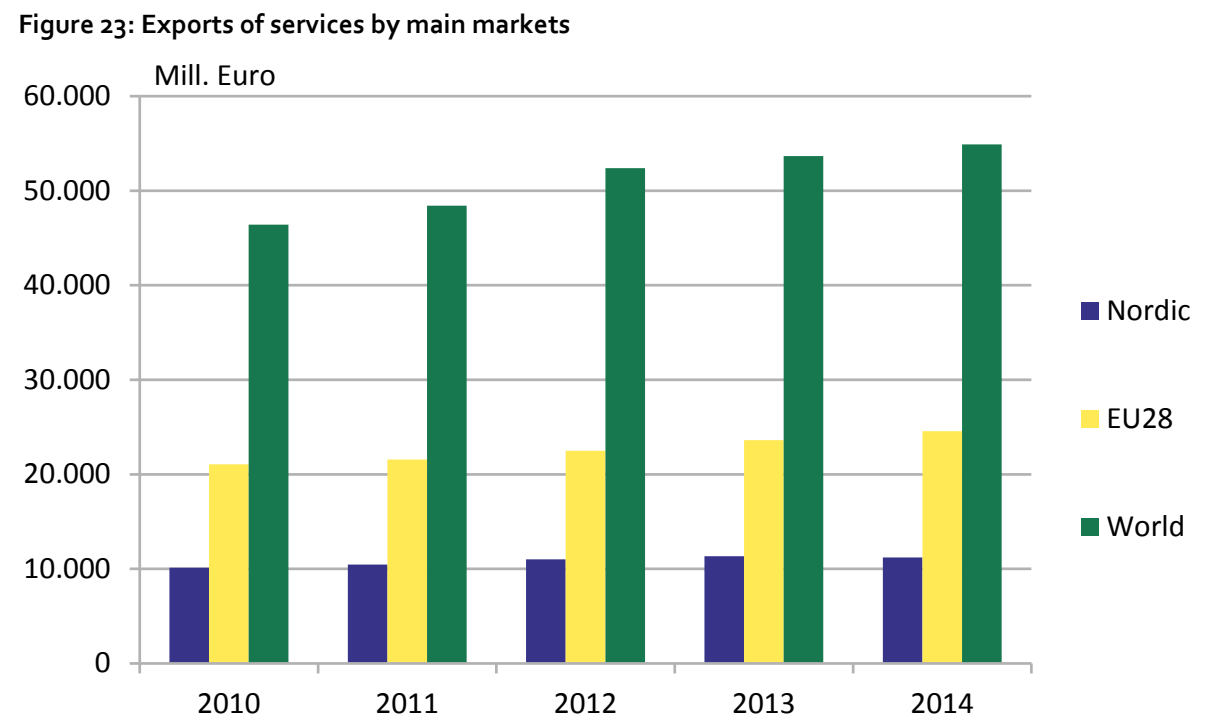

Source: See Annex 1.3.

The Nordic countries alone accounted for $22 \%$ of total Danish exports of services in 2010. In 2014 the share had dropped to $20 \%$. In absolute terms, Danish service exports to the Nordic countries increased from EUR 10.1 to 11.2 billion. Sweden was the undisputedly largest Nordic market for Danish service exports, accounting for $50 \%$ of Denmark's Nordic exports in 2014, corresponding to EUR 5.6 billion. 


\subsubsection{Strongholds}

Compared to the other Nordic countries, Danish exports in services are the least diversified. The largest service category, Transport services, accounted for more than $60 \%$ of the total exports in 2014 , corresponding to EUR 33.4 billion, cf. figure 24. Danish exports of transport services accounted for $10.6 \%$ of total EU28 exports of transport services in 2014. Sea transport is by far the most important transport service for Denmark.

Even in absolute numbers Denmark has a relative low level of knowledge-based ${ }^{11}$ service exports compared to the other Nordic countries e.g. Sweden.

Figure 24: Exports of services to all destinations (World) by service categories. 2014

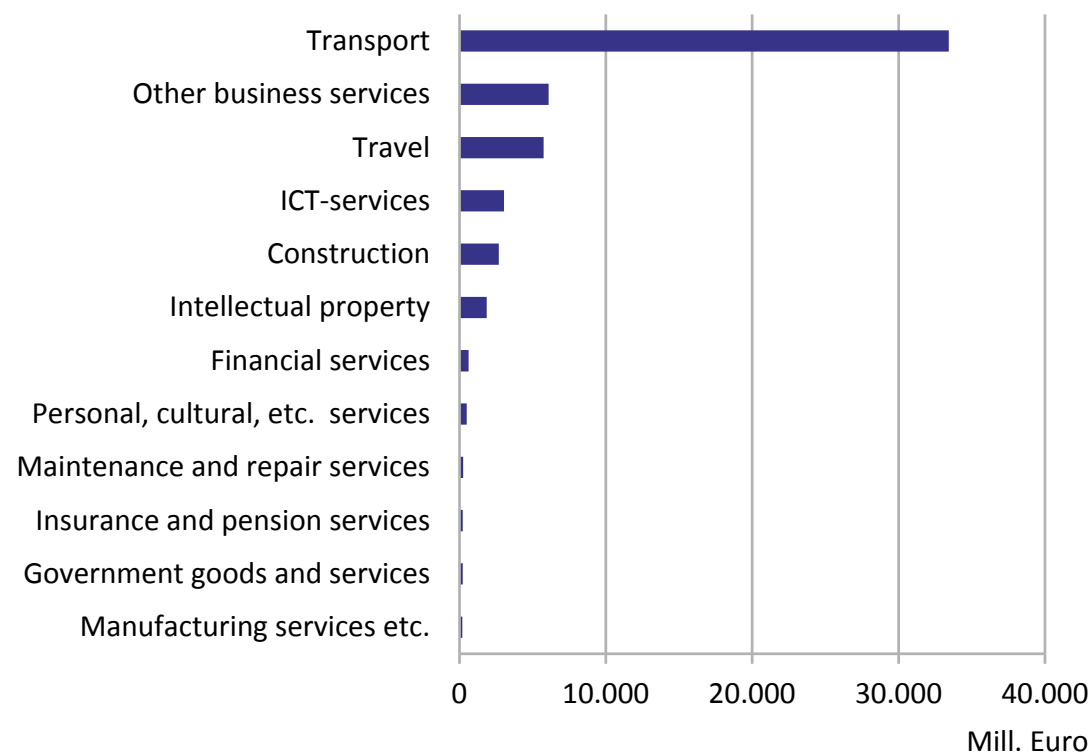

Source: See Annex 1.3

Danish service exports to the other Nordic countries are less specialised. Transport services still account for the largest part, however to a lesser extent than before. Travel services is the second largest export category, which is not surprising due to the fact that there is a lot of cross-border travelling within the Scandinavian region.

\footnotetext{
${ }^{11}$ Knowledge-based exports include services such as R\&D and IT services.
} 
Figure 25: Exports of services to the Nordic countries by service categories. 2014

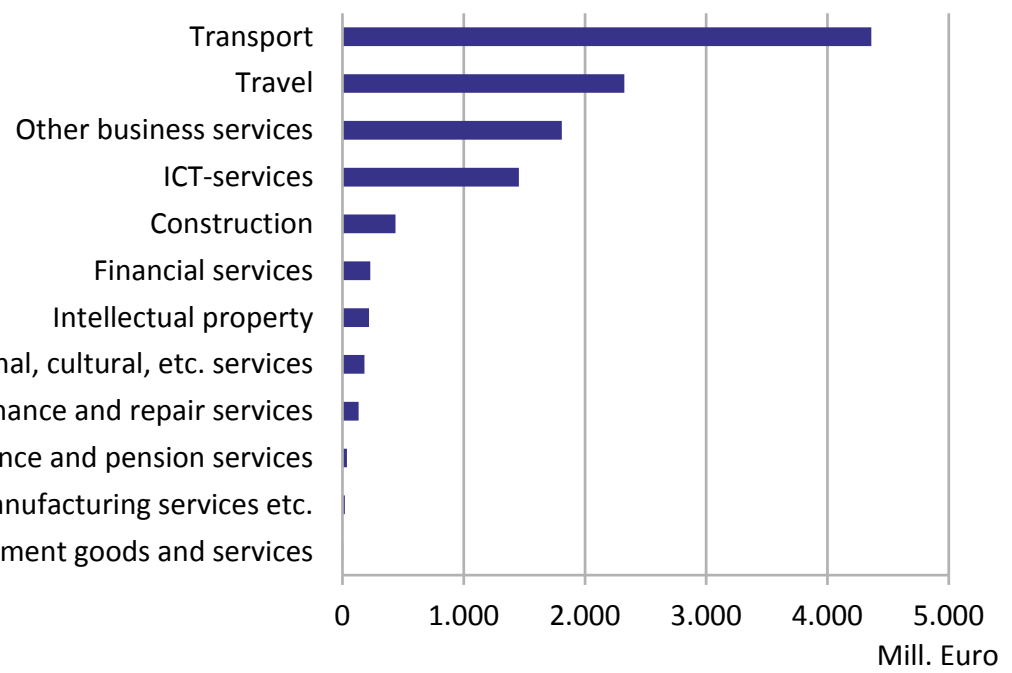

Source: See Annex 1.3.

\subsubsection{Part II. Exporters of services ${ }^{12}$}

Danish trade in services appear to be dominated by large enterprises. ${ }^{13}$ From 2010 to 2014, however, the exports by SMEs have grown.

The majority of exports from Denmark is exported by domestically controlled enterprises with affiliates abroad (67\%), cf. figure 26 . From 2010 to 2014 this picture has not changed. The pattern should be seen in the context of national strongholds, as the Danish stronghold, Transport services, is mainly exported by Danish owned companies with foreign affiliates.

\footnotetext{
${ }^{12}$ Note that the conclusions in this section are based on data with certain limitations. For more detailed information see the introduction to this chapter and annex 1.3.

${ }^{13}$ Please see chapter 2.1.2 on the uncertainty of the trade share between SMEs and large enterprises.
} 
Figure 26: Exports of services by ownership and enterprise size ${ }^{14}$

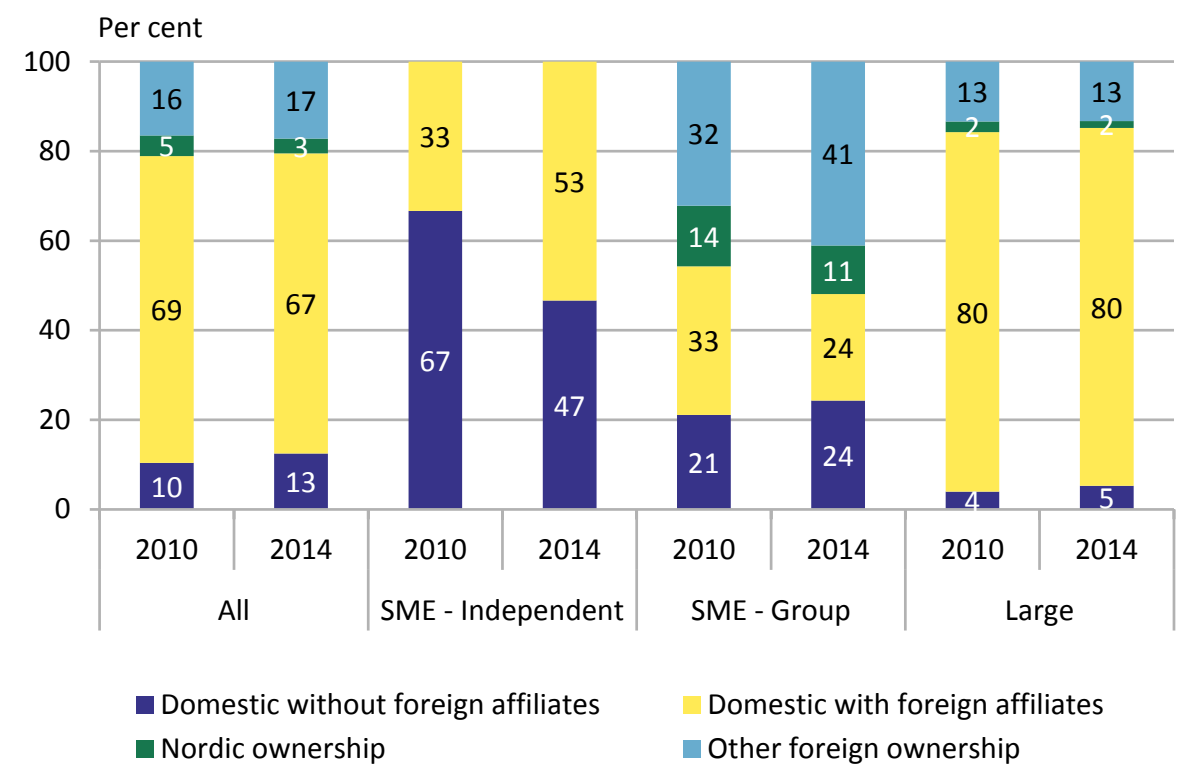

Source: National services trade surveys linked with statistical business registers. See Annex 1.3 for a more detailed description.

The pattern differs, however, across enterprise sizes. Exporting SMEs that are part of a group are a mix of domestic and foreign owned, where the latter now constitutes the largest part. The figure shows that exports by large enterprises are dominated by domestically controlled enterprises, which is also reflected in the overall picture.

The markets, that the exporting enterprises sell to, differ when looking at type of ownership, cf. figure 27. Domestically owned enterprises with affiliates abroad, export mostly to far-away markets, such as the US and China, whereas the majority of exports from domestically owned enterprises without foreign affiliates goes to the neighbouring markets.

\footnotetext{
${ }^{14}$ Based on new data material, we have refined the traditional statistical definition of SMEs from only being based on the employment size, i.e. enterprises with less than 250 persons employed, to also include information about dependency and external ownership as being part of an enterprise group. For a more detailed description see chapter 4.
} 
Figure 27: Exports of services by export markets and ownership. 2014

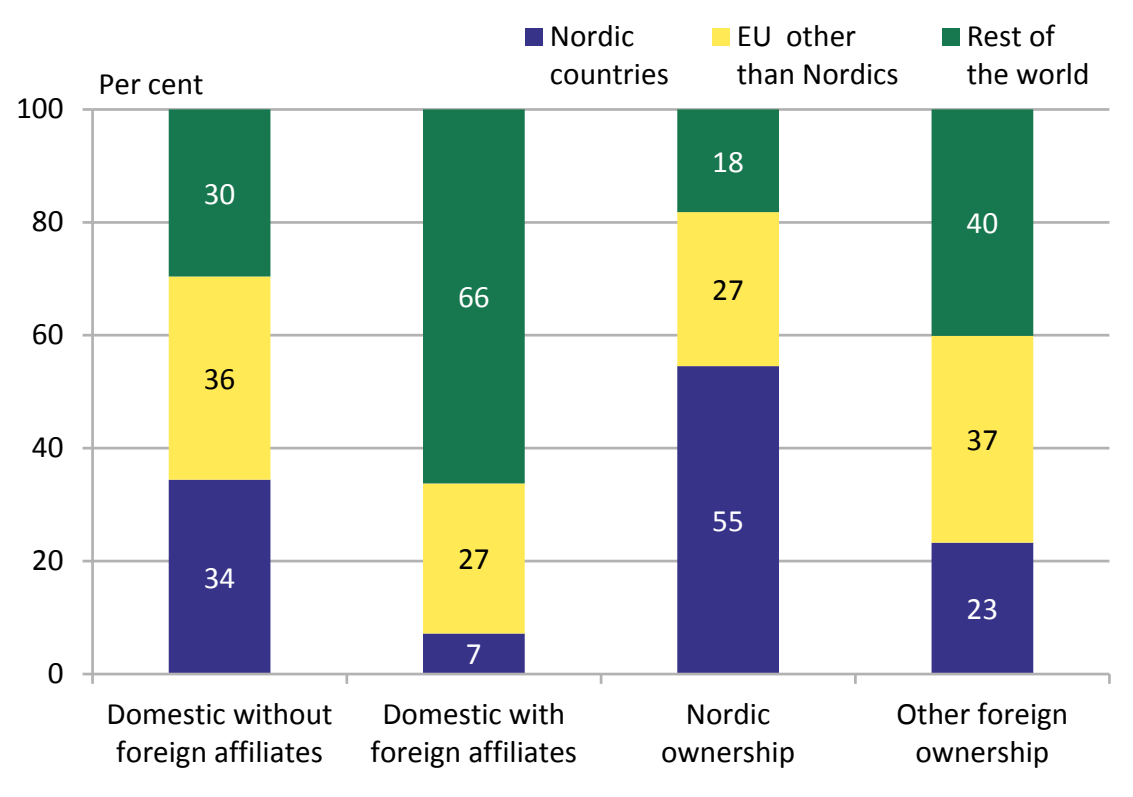

Source: National services trade surveys linked with statistical business registers. See Annex 1.3 for a more detailed description.

\subsection{Finland}

\subsubsection{Part I. Trade patterns and market trends}

Exports of services accounted for 10\% of Finland's GDP in 2014 making it, alongside Norway, the country with the lowest service exports intensity in the Nordic region. In 2014 Finland exported services for EUR 21.2 billion. Compared to the other larger Nordic countries Finland has the lowest share of EU exports in services, as Finnish exports constituted only $1.3 \%$ of total EU28 service exports in 2014.

As of 2011, Finnish imports of services have been higher than exports resulting in a deficit of the services account of EUR 1.8 billion in 2014, cf. figure 2.19 . 
Figure 28: Development in trade of services

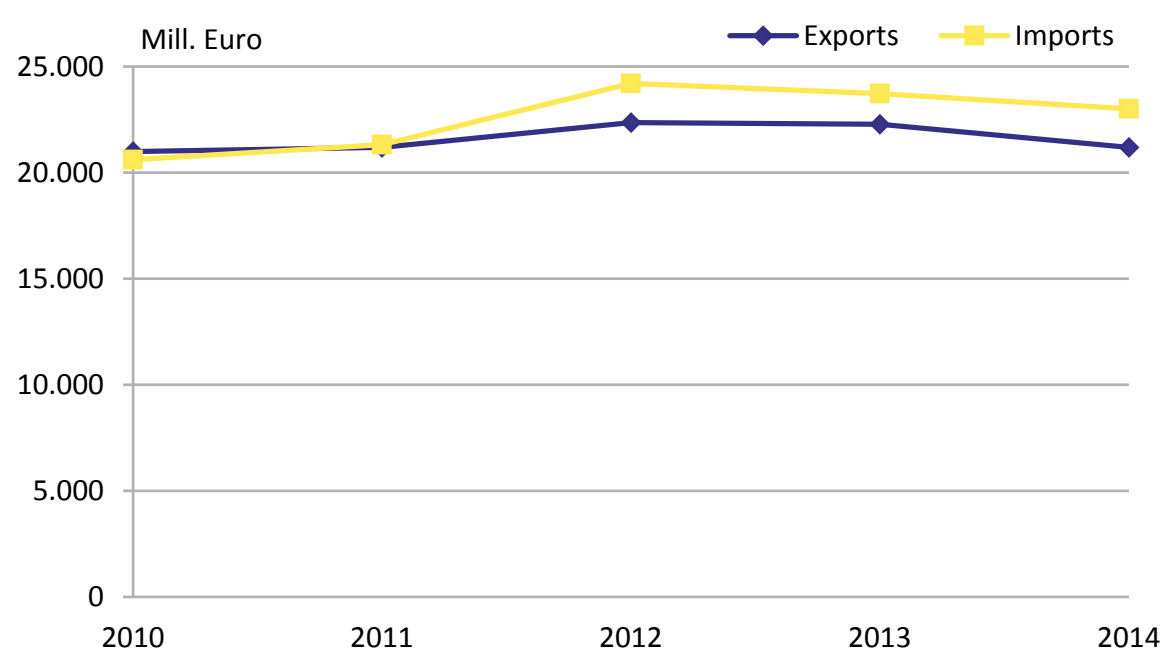

Source: See Annex 1.3

In the period from 2010 to 2014 Finland's service exports grew merely $0.9 \%$, which was the lowest increase in exports in the Nordic region. Finland's close to zero export growth is due to a fall in exports during the last two years of the period.

Figure 29: Development in trade of services

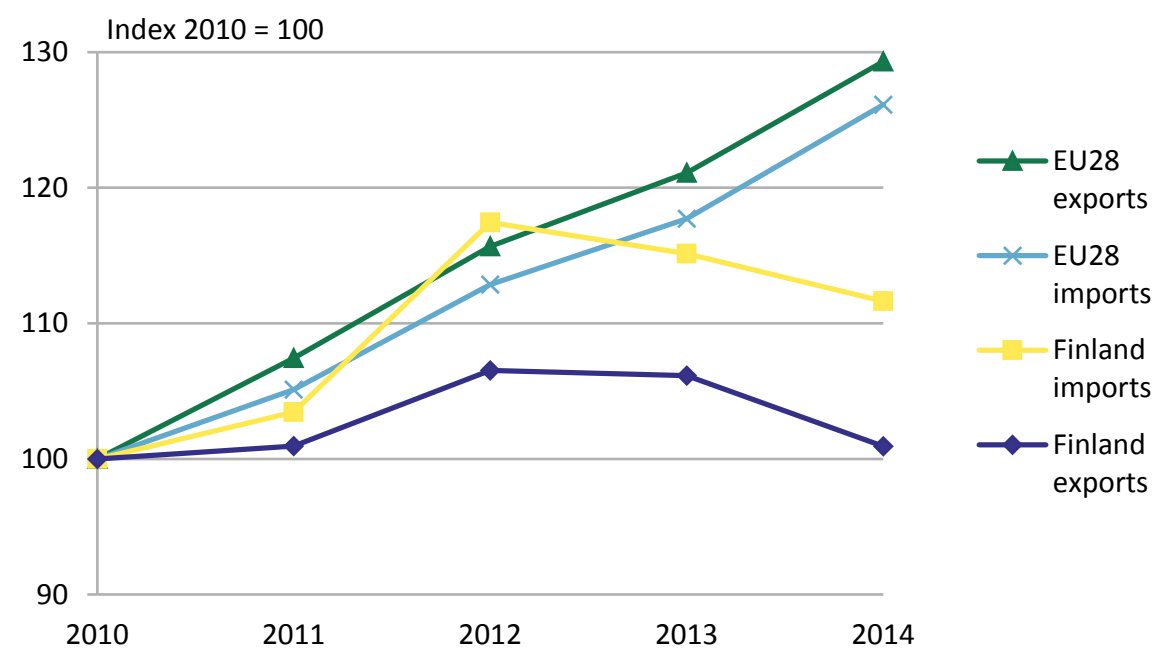

Source: See Annex 1.3. 
Compared to the EU28, Finland's export growth is also low. During the period 20102014 EU28 service exports increased by $29 \%$, cf. figure 29 . Consequently, the Finnish share of total EU28 exports dropped from $1.6 \%$ in 2010 to $1.3 \%$ in 2014.

\subsubsection{Market trends}

Most Finnish services are exported to other European countries, where the vast majority goes to other EU-member countries cf. figure 30. In 2014, exports to other EU countries made up $52.7 \%$ of total Finnish services export, corresponding to EUR 11.2 billion.

From 2010 to 2014 the export pattern of Finnish services has changed a little, cf. figure 31. The European market is receiving a larger part of Finnish service exports. In 2010 Europe received $51.8 \%$ of Finland's total service exports. By 2014, the share had increased to $65.5 \%$.

Figure 30: Exports of services by main markets

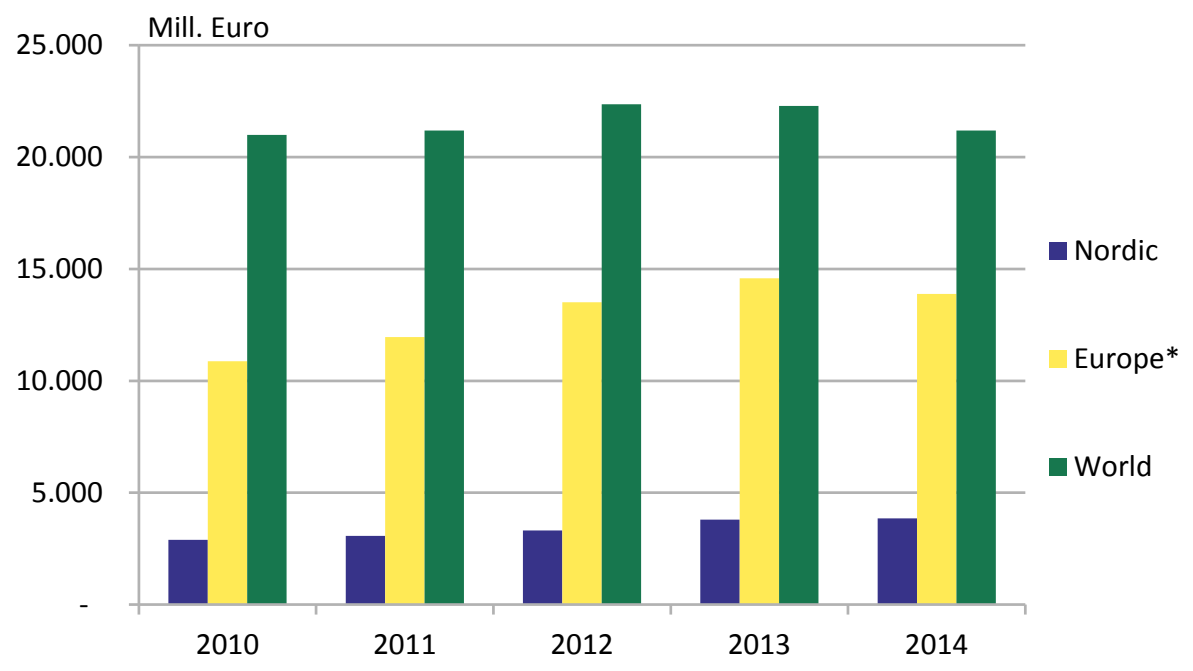

Note: Information on the trade with $\mathrm{EU}_{2} 8$ is not available for Finland. Figures for Europe are used instead.

Source: See Annex 1.3.

An increasing share of Finnish exports is going to the other Nordic countries. Thus, the larger European share may stem from an increased Nordic share of Finnish exports. From 2010 to 2014 the share of exports of services going to Finland's Nordic neighbours rose from $13.8 \%$ to $18.2 \%$. However, the share is still relatively low. Only, Norway exports a lower share to the Nordic region. 
The most significant country for Finnish service exports are Sweden. Services, equal to EUR 2.9 billion, were exported to Sweden in 2014, accounting for $76.0 \%$ of Finland's total service exports to the Nordic region and $13.8 \%$ of Finland's global service exports.

\subsubsection{Strongholds}

Finland's export pattern is more diversified with regard to service categories compared to e.g. Denmark and Iceland.

The biggest single item in Finnish service exports in 2014 was Telecommunication, computer, and information services, which accounted for almost one-third of total exports, corresponding to EUR 6.4 billion. Other service categoriess that make up a large share of Finnish exports include Other business services (16.9\% of total exports of services), Travel (12.8\%), and Transport (11.9\%), cf. figure 31.

Figure 31: Exports of services to all destinations (World) by service categories. 2014

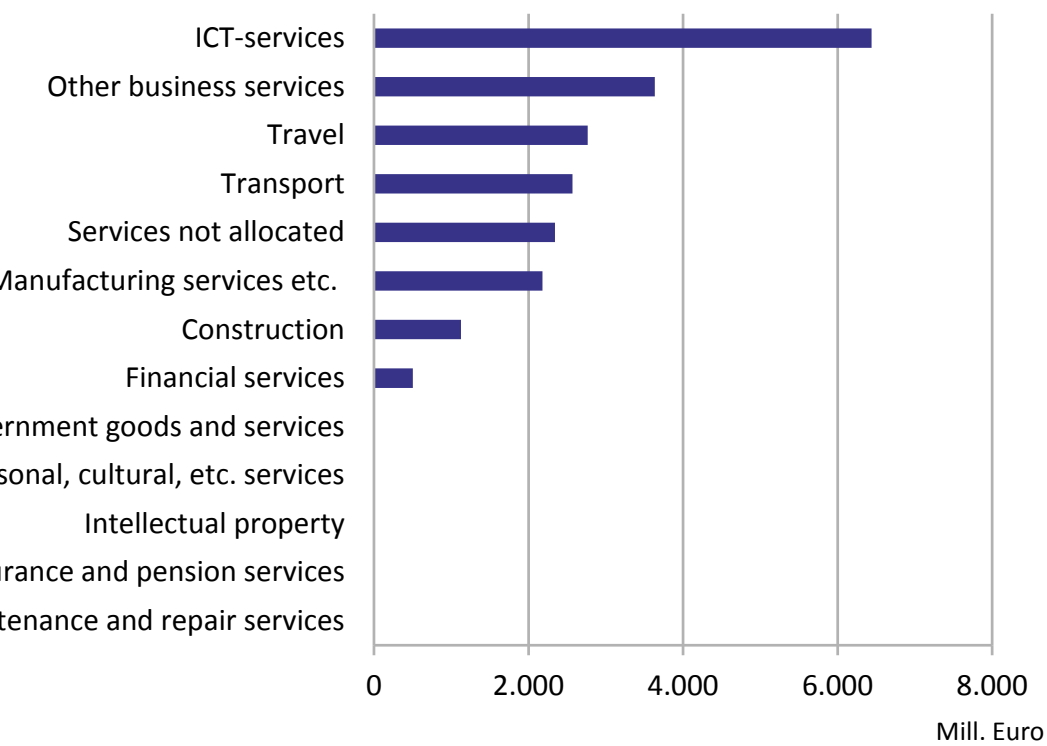

Note: Services such as maintenance and repair; insurance and pension; charges for IP; personal, cultural, and recreational; and governmental are included in Services not allocated.

Source: See Annex 1.3 


\subsubsection{Part II. Exporters of services ${ }^{15}$}

Large enterprises appear to account for most of Finland's exports in services. ${ }^{16}$ Nevertheless, the Finnish ICT industry has undergone major changes in recent years, which has made SMEs more important. The majority of Finnish service exports were exported by domestically controlled enterprises in 2010, but in 2014 this picture has dramatically changed, as foreign owned companies now accounts for $42 \%$ of the total export, an increase of 27 percentage points.

The pattern is explained by the major changes in the ICT industry. In 2010 service exporters in this industry was mainly Finnish owned companies; however in 2014, foreign owned enterprises have become the most important exporters for the industry.

Figure 32: Exports of services by ownership and enterprise size

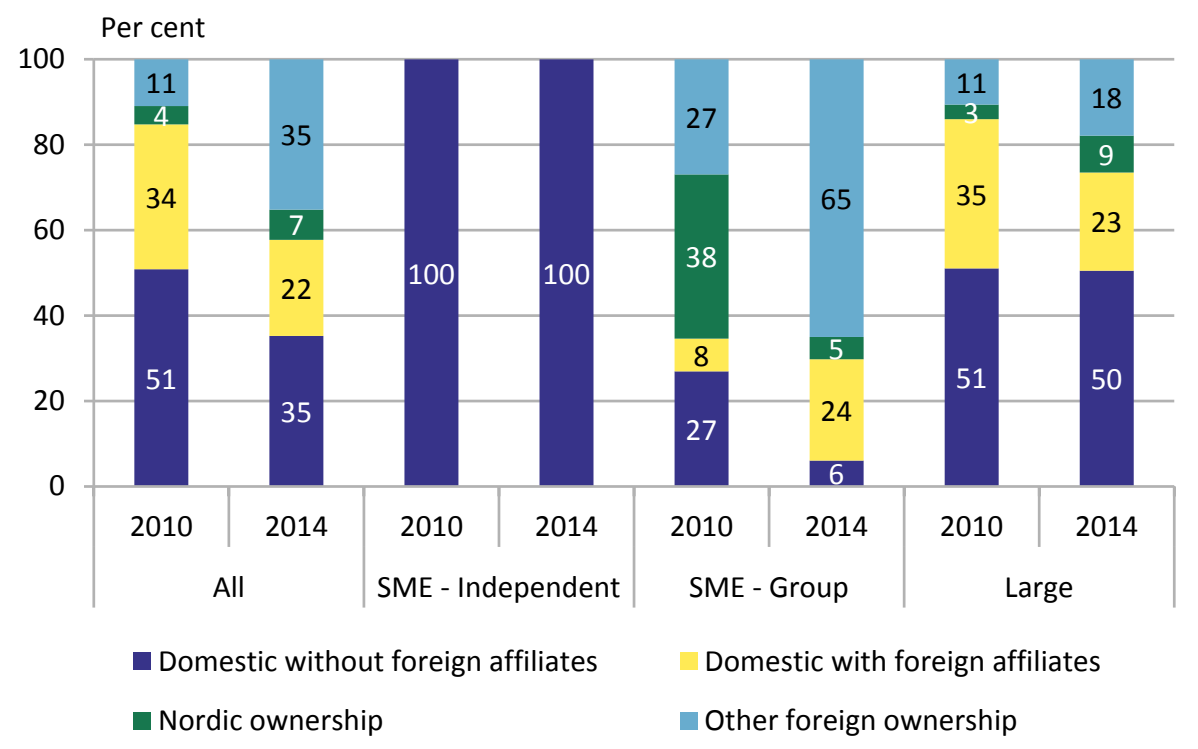

Source: National services trade surveys linked with statistical business registers. See Annex 1.3 for a more detailed description.

\footnotetext{
${ }_{15}$ Note that the conclusions in this section are based on data with certain limitations. For more detailed information see the introduction to this chapter and annex 1.3.

${ }^{16}$ Please see chapter 2.1.2 on the uncertainty of the trade share between SMEs and large enterprises.
} 
Figure 32 shows that the pattern differs across enterprise sizes. Looking at SMEs that are part of a group, the exports are spread over a mix of domestically and foreign owned enterprises. Looking at large enterprises on the other hand, domestically controlled enterprises still dominate service exports.

Figure 33: Exports of services by export markets and ownership. 2014

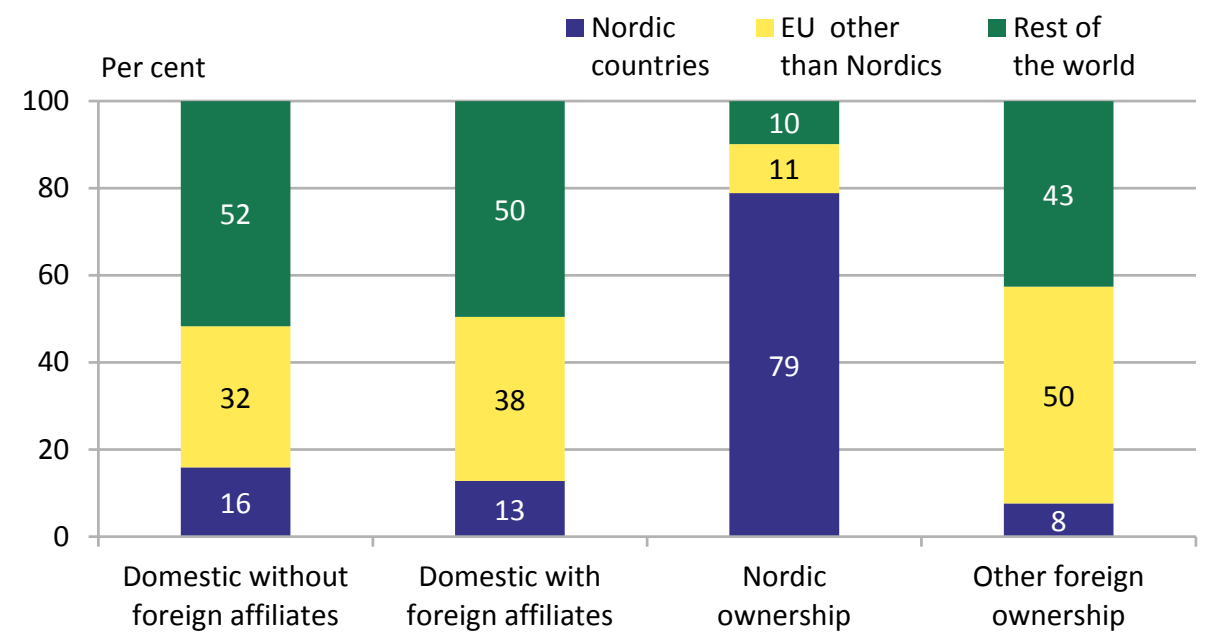

Source: National services trade surveys linked with statistical business registers. See Annex 1.3 for a more detailed description.

The majority of exports from Finnish owned enterprises go to non-Nordic countries, such as the US and Russian Federation, whereas most exports from foreign owned enterprises go to the large EU countries, cf. figure 33. As in Sweden, the investment may reflect a way to access the EU internal market.

Only a small share of total exports is conducted by Nordic owned enterprises. Exporting enterprises in Finland, that are Nordic owned, are extremely Nordic oriented, compared to Nordic owned enterprises in the other Nordic countries. 


\section{$2.4 \quad$ Iceland $^{17}$}

\subsubsection{Part I. Trade patterns and market trends}

Iceland is the smallest exporting economy in the Nordic region. In 2014 Icelandic exports of services amounted to EUR 3.2 billion, which is equivalent to $5.7 \%$ of Sweden's export. However, exports of services accounted for $25 \%$ of Icelandic GDP in 2014 making Iceland the most export oriented Nordic economy with regards to services.

Figure 34: Development in trade of services

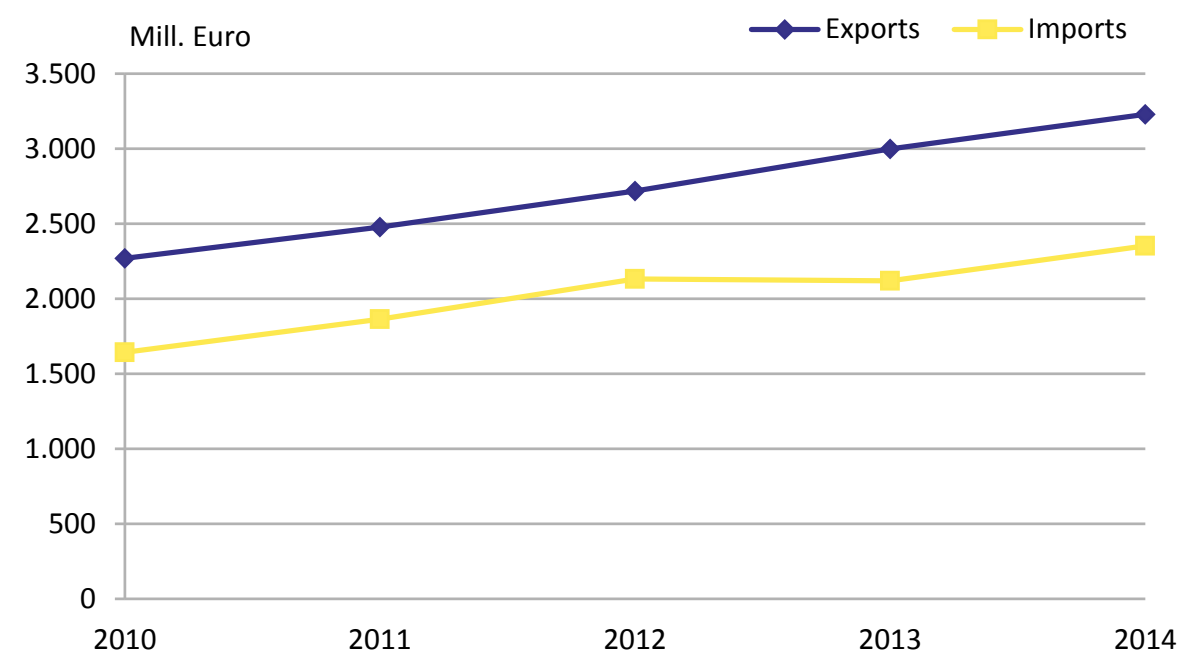

Source: See Annex 1.3

In the period from 2010 to 2014 Iceland's trade in services has increased substantially. Exports make up a larger part than imports, resulting in a trade in services surplus, cf. figure 34 .

From 2010 to 2014 Iceland has had the steepest growth in service exports compared to the other Nordic countries. Icelandic service exports increased by $42 \%$ in the four year period.

${ }_{17}^{17}$ Unfortunately, part II is missing for Iceland, as it has not been possible to get data on Icelandic exporters of services. 
Figure 35: Development in trade of services

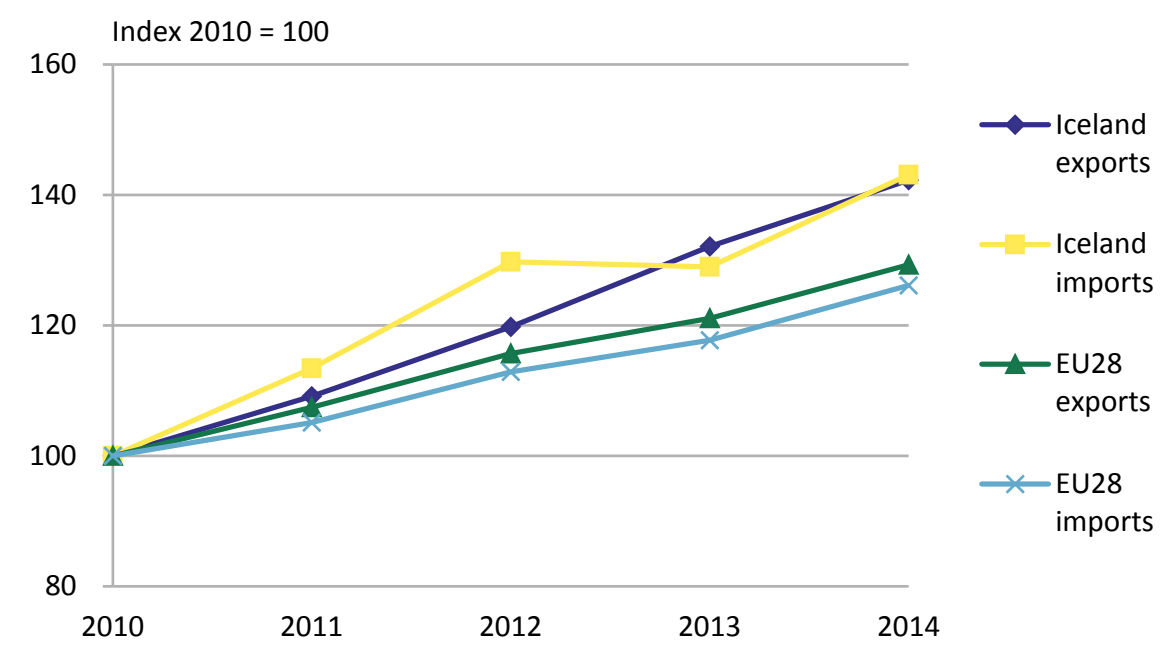

Source: See Annex 1.3.

The impressing growth is also apparent when comparing with total EU 28 exports in services, which increased $29 \%$ during the period cf. figure 35 . Except from Sweden, Iceland is the only Nordic country that has had a higher relative increase in service exports than the $\mathrm{EU}_{2} 8$.

\subsubsection{Market trends}

The Icelandic exports of services are becoming more global in the sense that the share of Icelandic exports of services going to the EU28 has dropped from $59.3 \%$ in 2010 to $43.9 \%$ in 2013, equal to EUR 1.3 billion, cf. figure 36 .

The largest single-country market for Icelandic exports in 2014 was the US, which accounted for nearly $17 \%$ of Icelandic exports. Nordic countries accounted for $23.1 \%$ of Icelandic service exports in 2013, making Iceland the second most Nordic-oriented, after Sweden. The largest trading partner of the Nordic countries is Denmark ( $41.1 \%$ of Icelandic exports of services go to the Danish market), followed by Norway (28.1\%), Sweden (24.4\%), and Finland (6.3\%). 
Figure 36: Exports of services by main markets

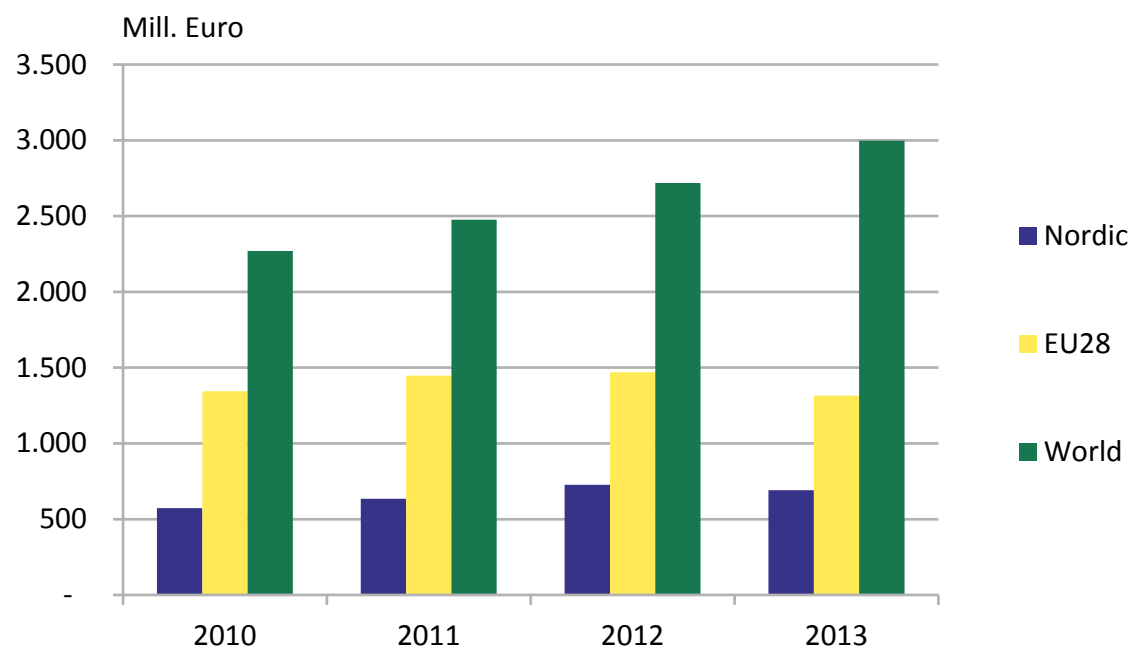

Source: See Annex 1.3.

\subsubsection{Strongholds}

Similar to Denmark, Iceland's export pattern is very specialised. The two largest service categories account for approximately $70 \%$ of Iceland's total exports of services. Exports of Transport services amounted to EUR 1.2 billion or $37.9 \%$, the largest share of Icelandic exports in 2014, cf. figure 37 .

Travel services amounted to 1 billion or $32.0 \%$. The tourism industry has been growing rapidly in recent years, and has now become one of Iceland's most important economic sectors. The number of travellers from especially the US and UK has soared since 2010, which explains the change in market shares discussed earlier, cf. figure $36 .{ }^{18}$

18 Íslandsbanki Research (2016). Tourism in Iceland. Available from www.islandsbanki.is/english/products-and-services/international-lending/tourism-industry-report/ 
Figure 37: Exports of services to all destinations (World) by service categories. 2014

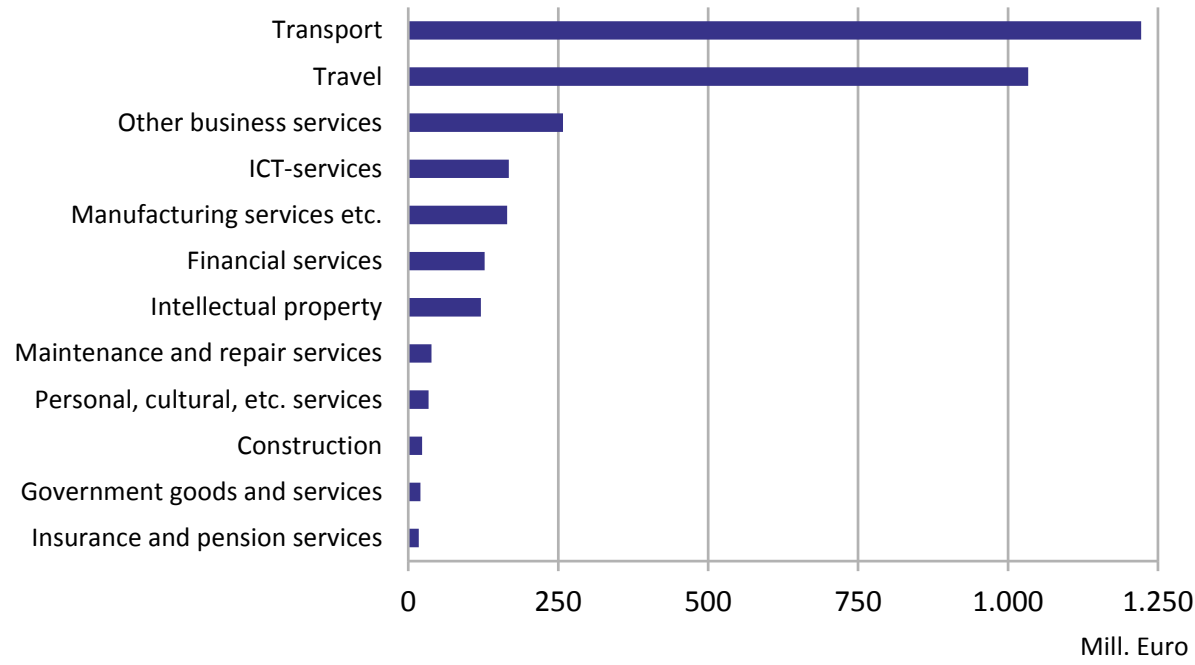

Source: See Annex 1.3

When looking at the Icelandic exports of services to the other Nordic countries the picture slightly changes, cf. figure 38. Transport is still the largest category of exports; however, Travel counts for a much smaller part. This is expected, as tourists from the US and UK constitute half of the tourists visiting Iceland. 
Figure 38: Exports of services to the Nordic countries by service categories. 2014

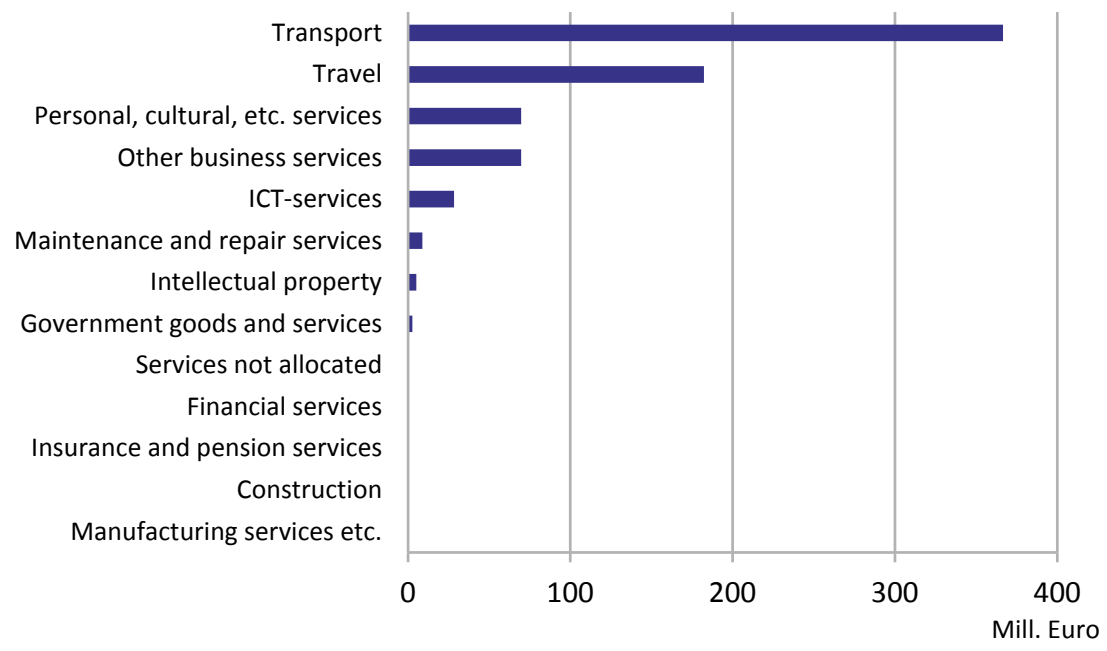

Note: Services such as financial, insurance and pension; construction; and manufacturing are included in Services not allocated.

Source: See Annex 1.3.

\subsection{Norway}

\subsubsection{Part I. Trade patterns and market trends}

Compared to its Scandinavian neighbours, Denmark and Sweden, Norway is not a large exporter of services. In 2014, Norway exported services for a total of EUR 37.8 billion, which is only a little bit more than two-thirds of the other countries' service exports. Norwegian exports of services accounted for 10\% of GDP in 2014.

Norway's exports of services increased $20 \%$ in the period 2010 to 2014 , as figure 39 illustrates. However, imports of services have been higher during the entire period resulting in a trade in services deficit. 
Figure 39: Development in trade of services

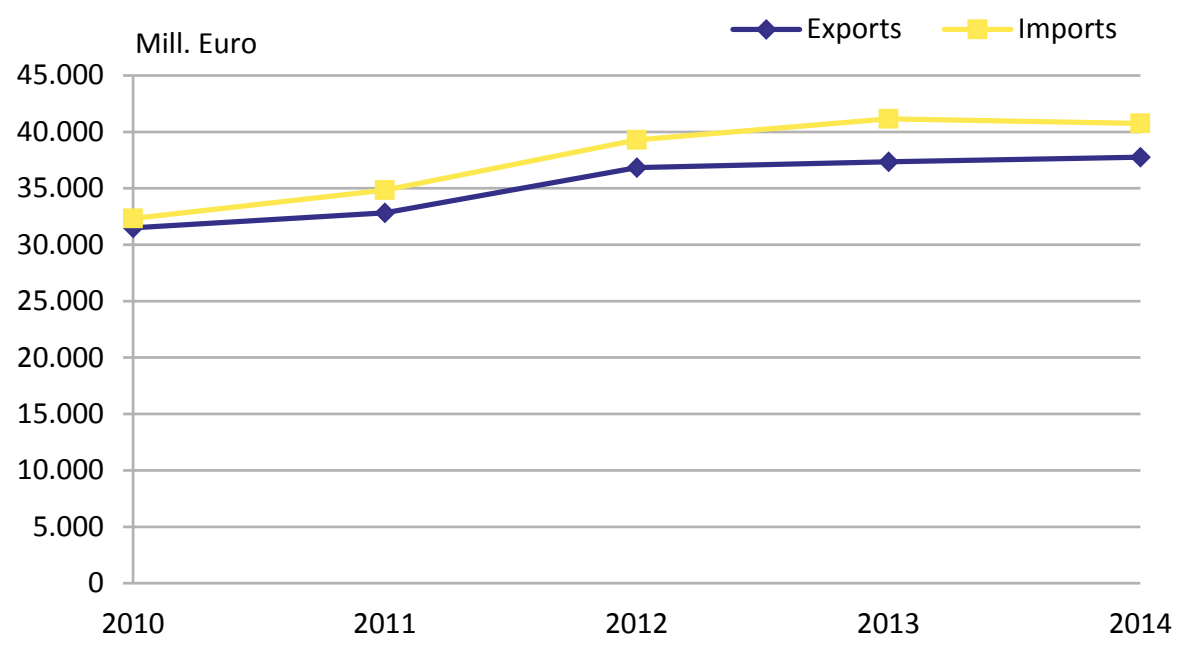

Source: See Annex 1.3

When comparing the development in services trade from 2010 to 2014 with the $\mathrm{EU}$, it appears that Norwegian exports grew at a slower pace than EU's, as service exports from total EU 28 increased $29 \%$ during the period, cf. figure 40.

Figure 40: Development in trade of services

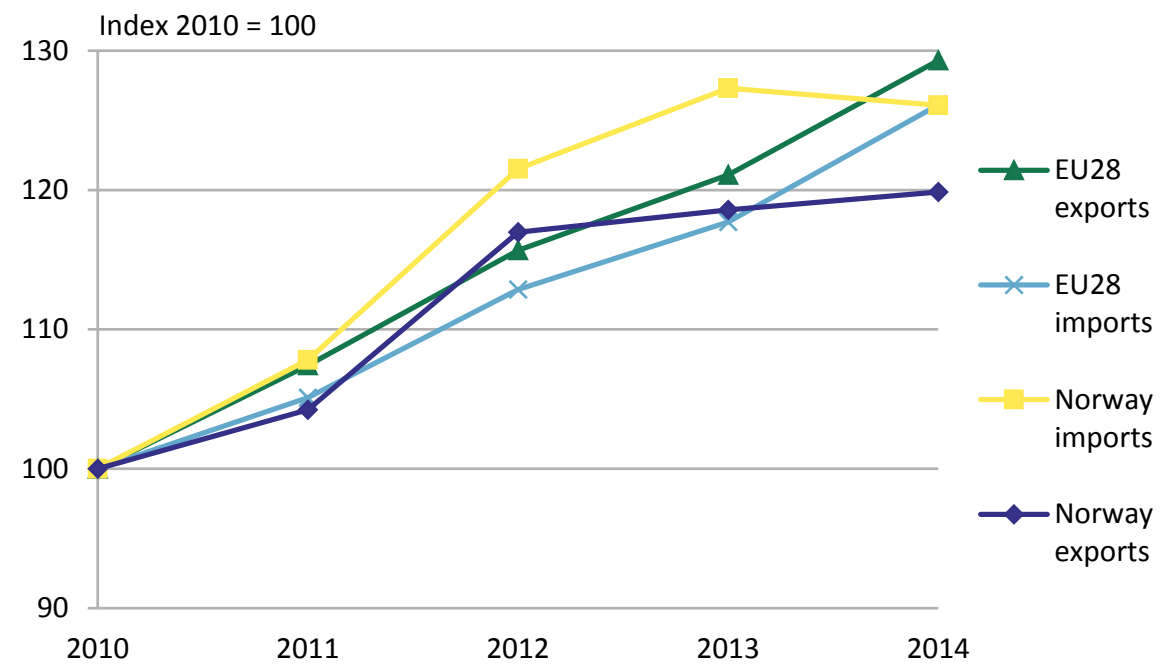

Source: See Annex 1.3 


\subsubsection{Market trends}

Extensive trade is conducted with the EU, which is the most important market for Norwegian service exports. Compared to the other Nordic countries Norway is by far the most EU-oriented country. In 2014, $66.7 \%$ of Norwegian service exports went to the EU28, cf. figure 41.

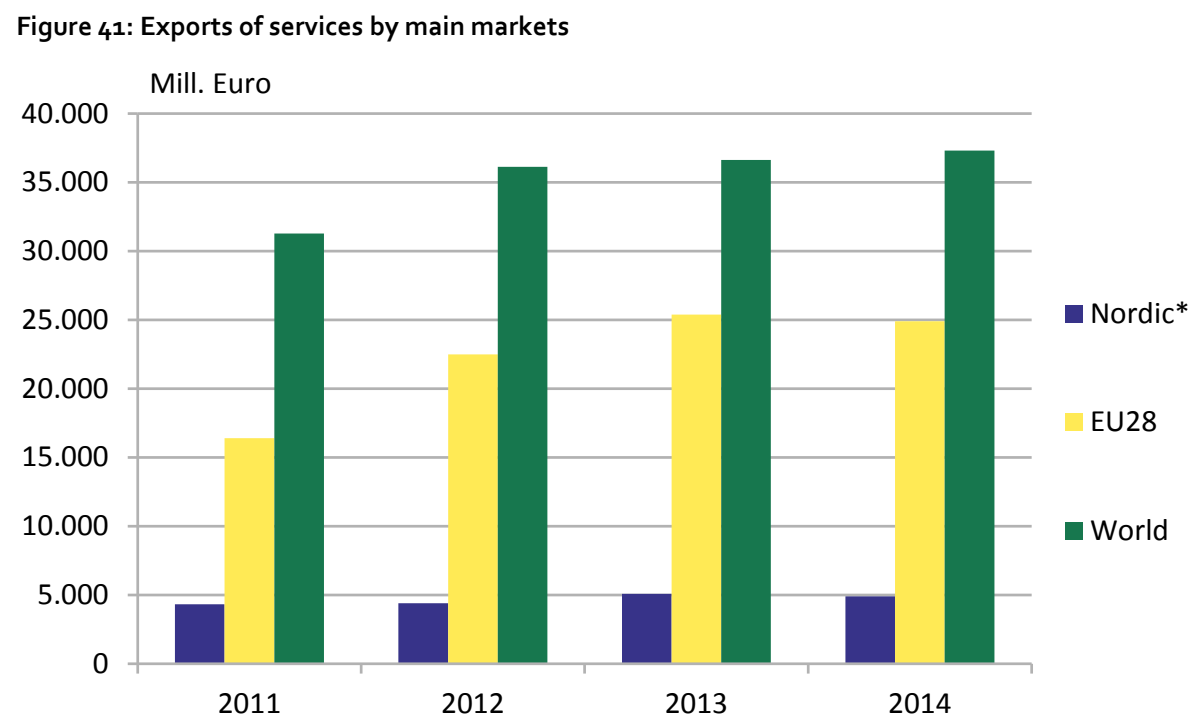

Note: Nordic does not include Iceland and Finland.

Source: See Annex 1.3.

In absolute terms, Norwegian exports to EU28 have increased from EUR 16.4 billion in 2011 to EUR 24.9 billion in 2014, resulting in an increase in the share of exports going to the EU from $52.4 \%$ to $66.7 \%$.

In 2014 Sweden and Denmark accounted for $13.1 \%$ of Norwegian exports in services, equivalent to EUR 4.9 billion.

\subsubsection{Strongholds}

Norway is a global player within transport services, and similar to Denmark, sea transport is most important. Exports of Transport services accounted for the largest part of Norwegian service exports in 2014 amounting to 11.1 billion (corresponding to $29.2 \%$ of total exports in services). It was followed by Financial services (21.9\%), and Telecommunications, computer, and information services (17.3\%), cf. figure 42 . 
Figure 42: Exports of services to all destinations (World) by service categories. 2014

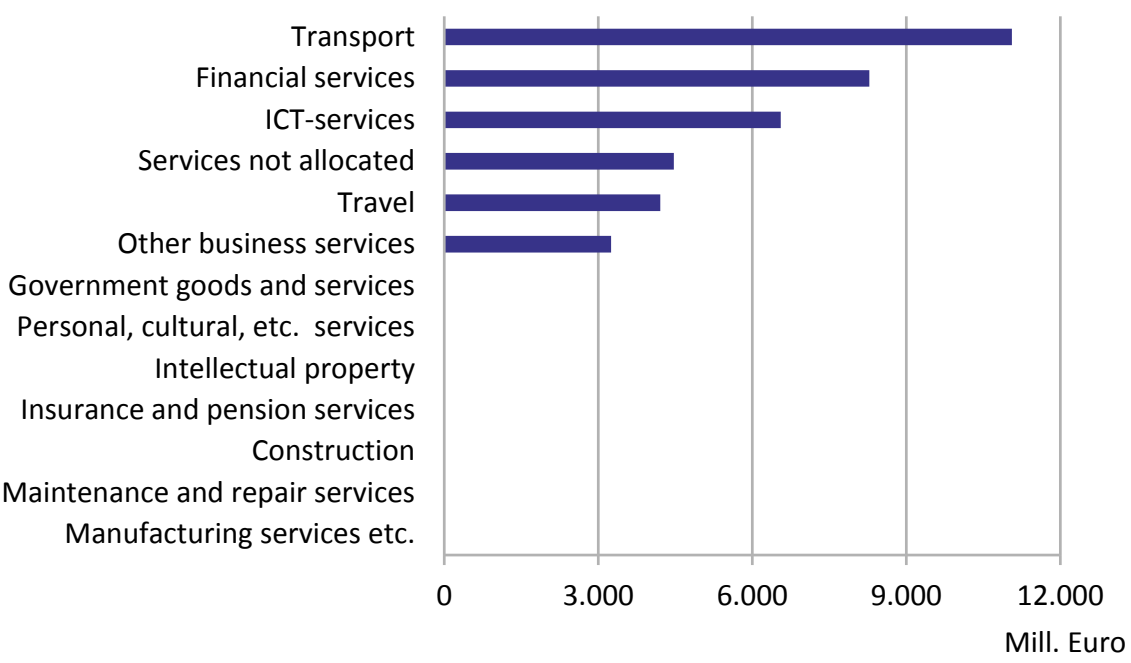

Note: Services such as manufacturing, maintenance and repair; construction; insurance and pension; charges for IP; personal, cultural, and recreational; and governmental are included in Services not allocated.

Source: See Annex 1.3.

Norway's export pattern is much more diversified than the Danish. The three largest service segments in Norwegian exports constituted $68.5 \%$ in 2014, which is almost the same as the transport industry itself accounted for in Danish exports. Furthermore, knowledge-based exports are also setting a footprint on Norway's service exports.

\subsubsection{Part II. Exporters of services ${ }^{19}$}

Compared to the other Nordic countries, SMEs appear to play a larger role in Norwegian trade in services. ${ }^{20}$ This is the case with regards to both exports and imports.

Most exports from Norway are exported by domestically controlled enterprises, cf. figure 43. The exports from enterprises with no affiliates abroad are still the largest in 2014, but from 2010 to 2014 the share of exports carried out by domestically owned

\footnotetext{
19 Note that the conclusions in this section are based on data with certain limitations. For more detailed information see the introduction to this chapter and annex 1.3.

${ }^{20}$ See chapter 2.1.2 on the uncertainty of the trade share between SMEs and large enterprises.
} 
enterprises with affiliates abroad has increased. One of Norway's strongholds is Transport services, which is mainly exported by Norwegian owned companies.

Figure 43: Exports of services by ownership and enterprise size

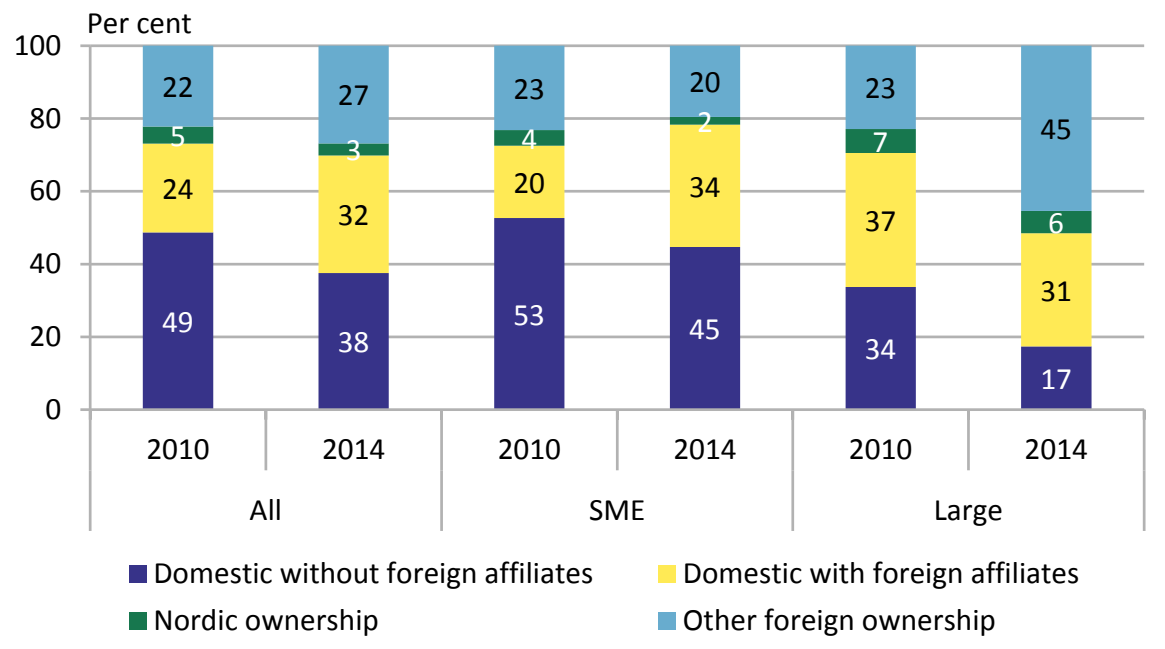

Source: National services trade surveys linked with statistical business registers. See Annex 1.3 for a more detailed description.

Looking across enterprise sizes a difference in ownership patterns emerge. In the period 2010 to 2014, the share of exports stemming from domestic owned SMEs has increased, compared to foreign owned SMEs. The opposite is the case when looking at the large enterprises. 
Figure 44: Exports of services by export markets and ownership. 2014

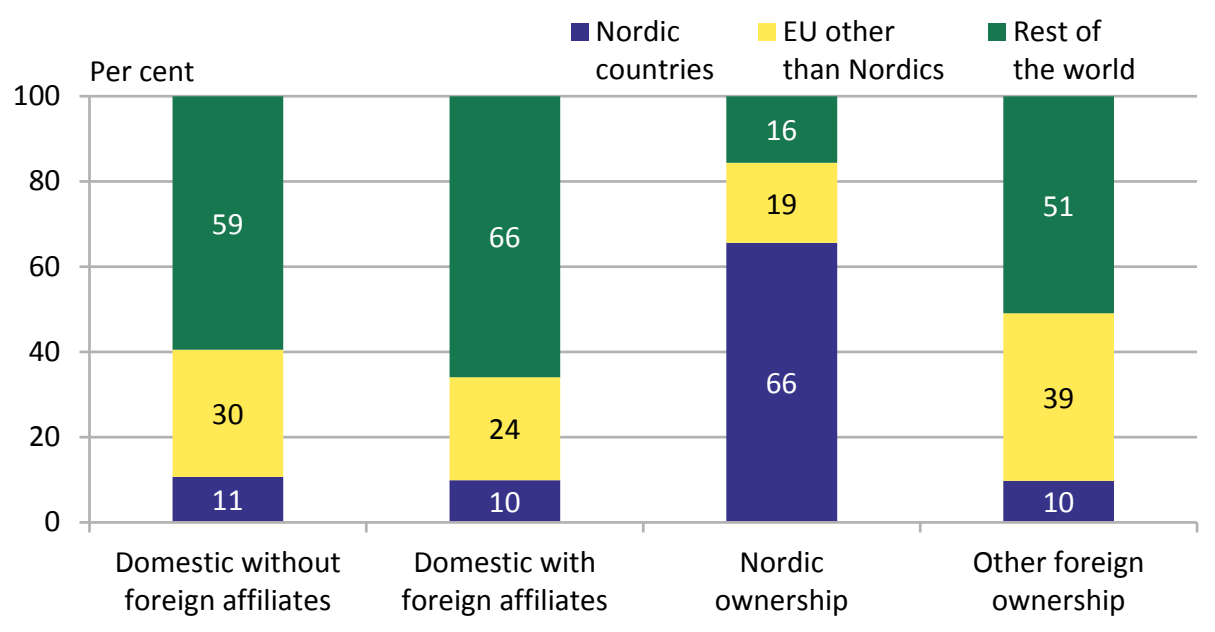

Source: National services trade surveys linked with statistical business registers. See Annex 1.3.

The market pattern of service exports is rather similar across type of ownership of the exporting enterprise, cf. figure 44 - with an exception of Nordic owned enterprises that are much more Nordic oriented. Services are exported mostly to far-away markets, such as the US. The majority of exports that goes to the neighbouring markets goes to the larger EU countries.

\subsection{Sweden}

\subsubsection{Part I. Trade patterns and market trends}

Service exports constituted $13 \%$ of Sweden's GDP in 2014, amounting to EUR 56.6 billion.

Swedish service exports increased $38 \%$ from 2010 to 2014 . Imports have also increased, but to a lesser degree, strengthening the trade in services figures. However, from 2013 to 2014 imports increased more than exports, which consequently led to a reduction in the trade in services surplus for the first time after a period of an increasing surplus, cf. figure 45 . 
Figure 45: Development in trade of services

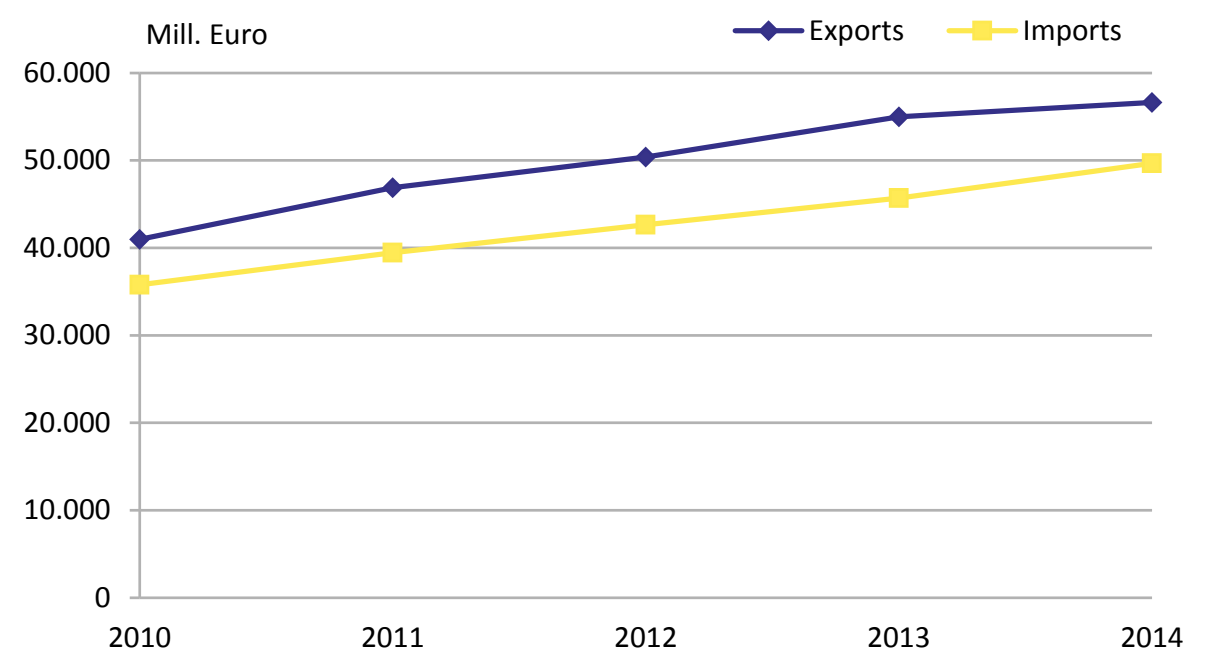

Source: See Annex 1.3.

In the period from 2010 to 2014 Sweden has experienced a larger increase in services trade than the EU as a whole, cf. figure 46, and Iceland is the only other Nordic country that has had a steeper growth in the period.

Figure 46: Development in trade of services

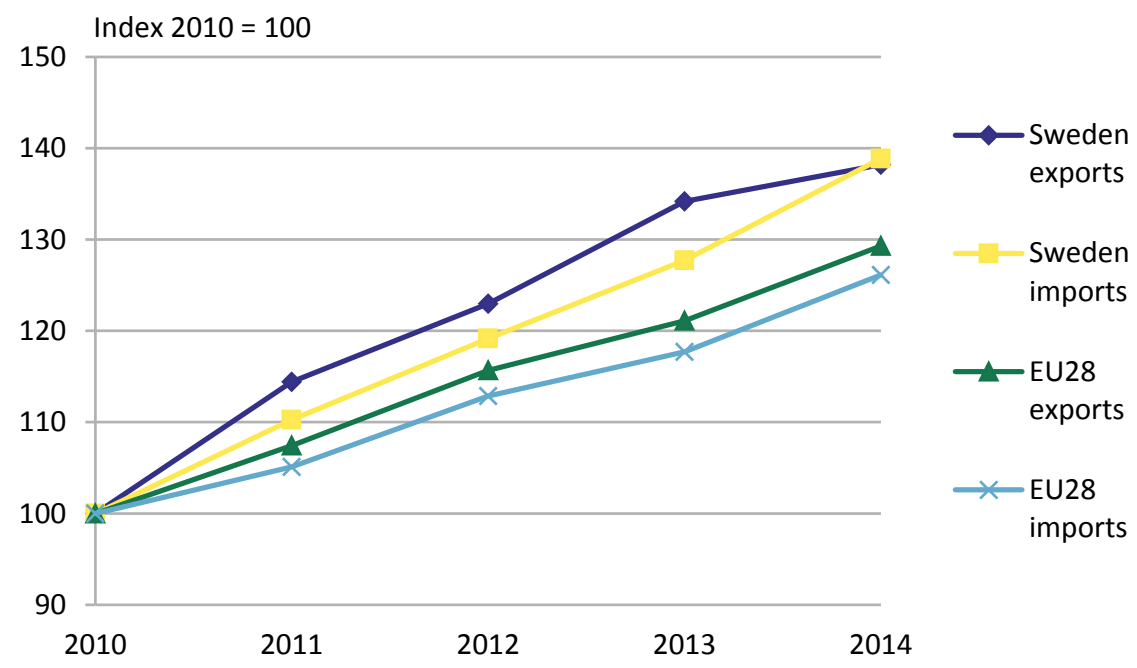

Source: See Annex 1.3. 
While Sweden's exports in services increased by $38.2 \%$ during the period, exports for all $\mathrm{EU}_{2} 8$ member states grew $29.3 \%$. Consequently, the Swedish share of EU exports rose to $3.4 \%$ in 2014 from $3.1 \%$ in 2010 .

\subsubsection{Market Trends}

The overall pattern of market destinations for Swedish exports has remained rather stable during the period 2010 to 2014 , cf. figure 47.

A bit more than half of all Swedish service exports go to other EU countries. In absolute numbers, Swedish exports to EU28 have increased, from EUR 21.4 billion in 2010 to EUR 29.5 billion in 2014. Germany and Great Britain were the most important EU export destinations for Sweden in 2014 , accounting for $8.1 \%$ and $7.4 \%$ respectively, of total Swedish exports in services.

Figure 47: Exports of services by main markets

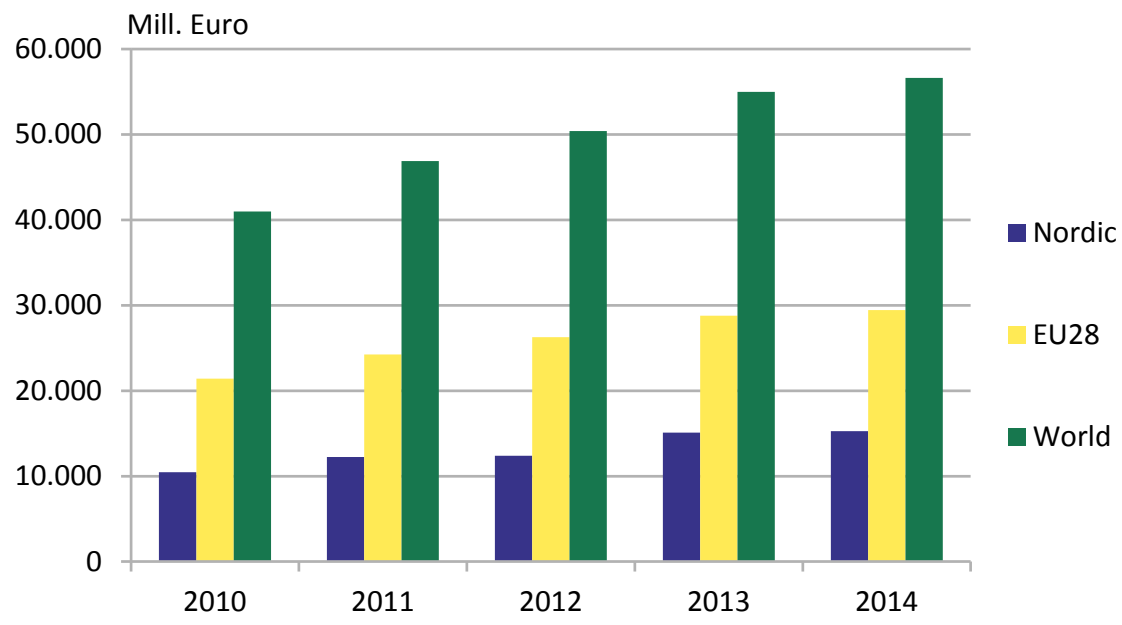

Source: See Annex 1.3

Compared to its Nordic neighbours Sweden is the most Nordic-oriented country with regards to exports in services, as $27.0 \%$ of Swedish exports went to other Nordic countries in 2014. Norway is the largest counterpart country for Swedish exports of services - not just in the Nordic region but also worldwide. In 2014, Swedish services going to Norway totalled EUR 7.8 billion or $13.7 \%$ of total Swedish exports in services. Travel services accounted for more than half of the exported services. The US accounted for $11.5 \%$ of total service exports making it the second biggest market for Swedish service exports. 


\subsubsection{Strongholds}

Four service categories account for almost four fifths of total Swedish service exports; Other business services (25.2\%), Telecommunications computer, and information services (21.1\%), Travel (17.1), and Transport (14.1\%), cf. figure 48 .

The industry aggregated category Other business services is the most important services category with regards to Swedish exports. It covers knowledge-intensive industries, such as the Research and devolvement services and Engineering services. In 2014 Other business services amounted to EUR 14.3 billion.

Figure 48: Exports of services to all destinations (World) by service categories. 2014

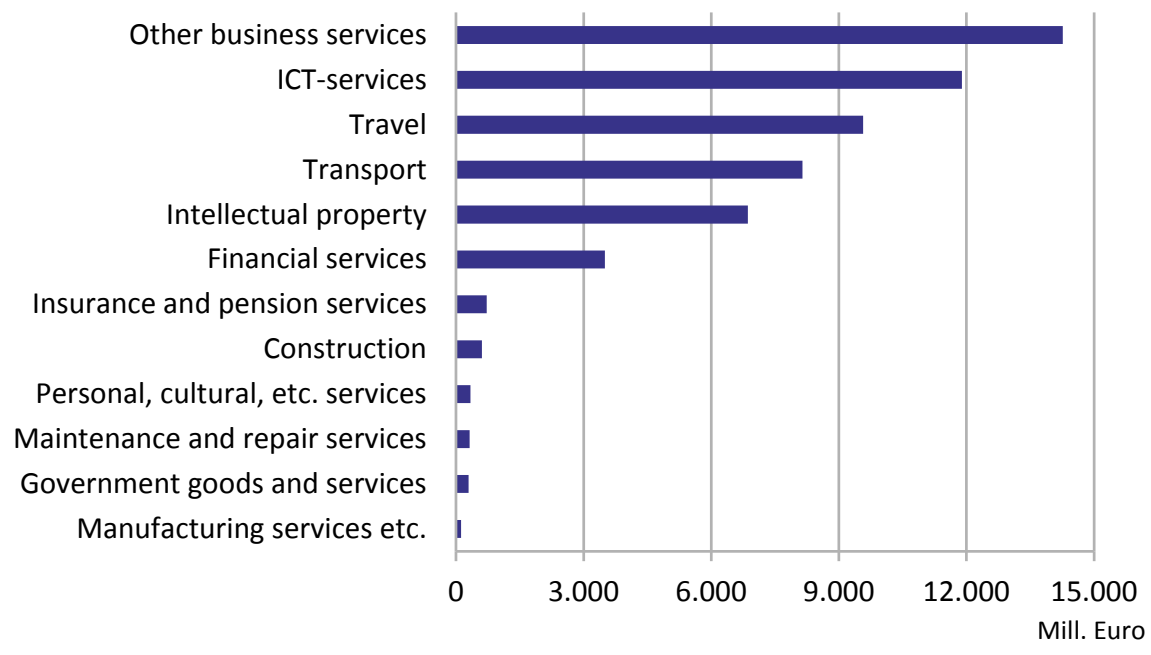

Source: See Annex 1.3.

One of Sweden's strongholds is Telecommunication, computer, and information services, where computer services make up the lion's share. Exports of computer services have been the fastest growing of Swedish service exports in recent years. The category covers, among other things, system development and IT consulting services. ${ }^{21}$ This Swedish stronghold is to a large part exported to the US.

${ }^{21}$ Unionen, Almega och Teknikföretagen (2011). Ekonomiska förutsättningar - Teknikindustri och tjänster inför avtalsrörelsen 2011. Available from www.almega.se/politik-och-ekonomi?typ=rapporter. 
Looking at Swedish exports to the Nordic region, the pattern changes. Travel is by far the largest exporting service category amounting to EUR 5.7 billion in 2014, equivalent to $37.5 \%$ of total Swedish service exports to the Nordic countries, cf. figure 49.

Figure 49: Exports of services to the Nordic countries by service categories. 2014

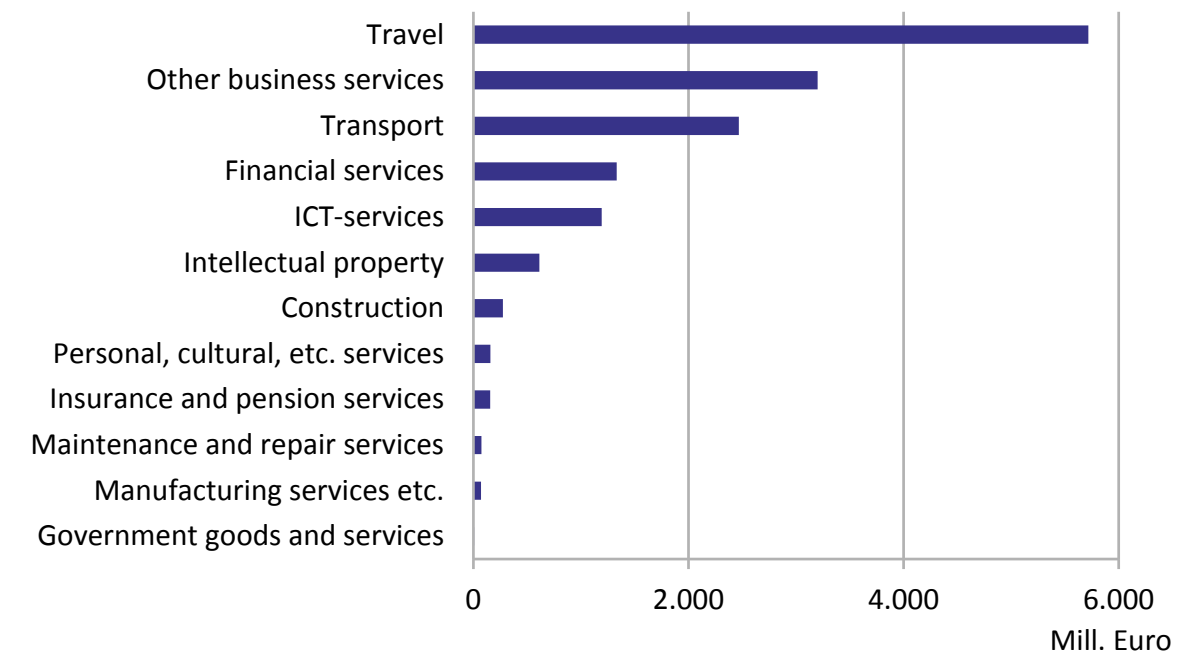

Source: See Annex 1.3 


\subsubsection{Part II. Exporters of services ${ }^{22}$}

Swedish service exports seem to be dominated by large enterprises, which is a trend that has increased from 2010 to 2014.

Figure 50: Exports of services by ownership and enterprise size

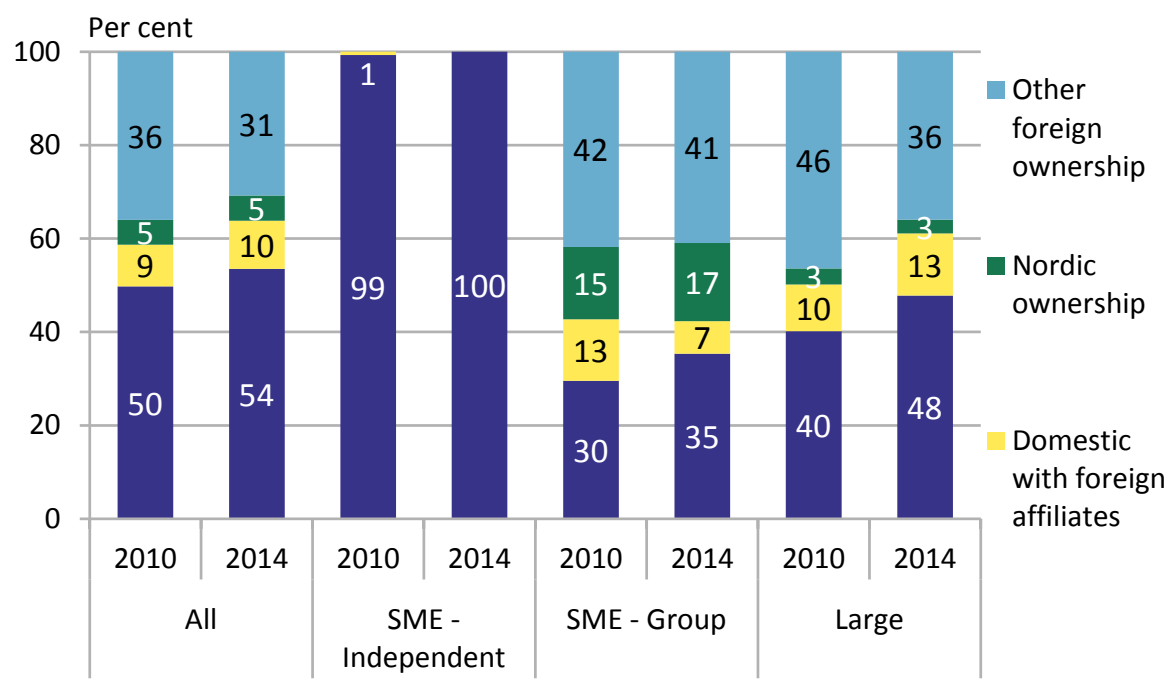

Source: National services trade surveys linked with statistical business registers. See Annex 1.3 for a more detailed description.

Approximately half of all Swedish exports are carried out by domestically owned enterprises without foreign affiliates. Still, more than $30 \%$ of exports are carried out by foreign owned enterprises, cf. figure 50.

Telecommunication, computer, and information services are to a large extent exported by Swedish owned companies. Nevertheless, enterprises owned by foreigners are also quite common within this industry, which may explain the relatively high share of exports conducted by foreign owned enterprises compared to the other Nordic countries. ${ }^{23}$

Domestically owned enterprises without foreign affiliates are more globally oriented than domestically owned enterprises that do have foreign affiliates, cf. figure 51.

${ }^{22}$ Note that the conclusions in this section are based on data with certain limitations. For more detailed information see the introduction to this chapter and annex 1.3.

23 Tillväxtanalys (2015). Utländska företag 2014. Available from www.tillvaxtanalys.se/publikationer/statistikserien/ statistikserien/2015-06-25-utlandska-foretag-2014.html 
Most exports, carried out by domestically owned enterprises without affiliates abroad, go to far-away markets, such as the US.

Figure 51: Exports of services by export markets and ownership. 2014

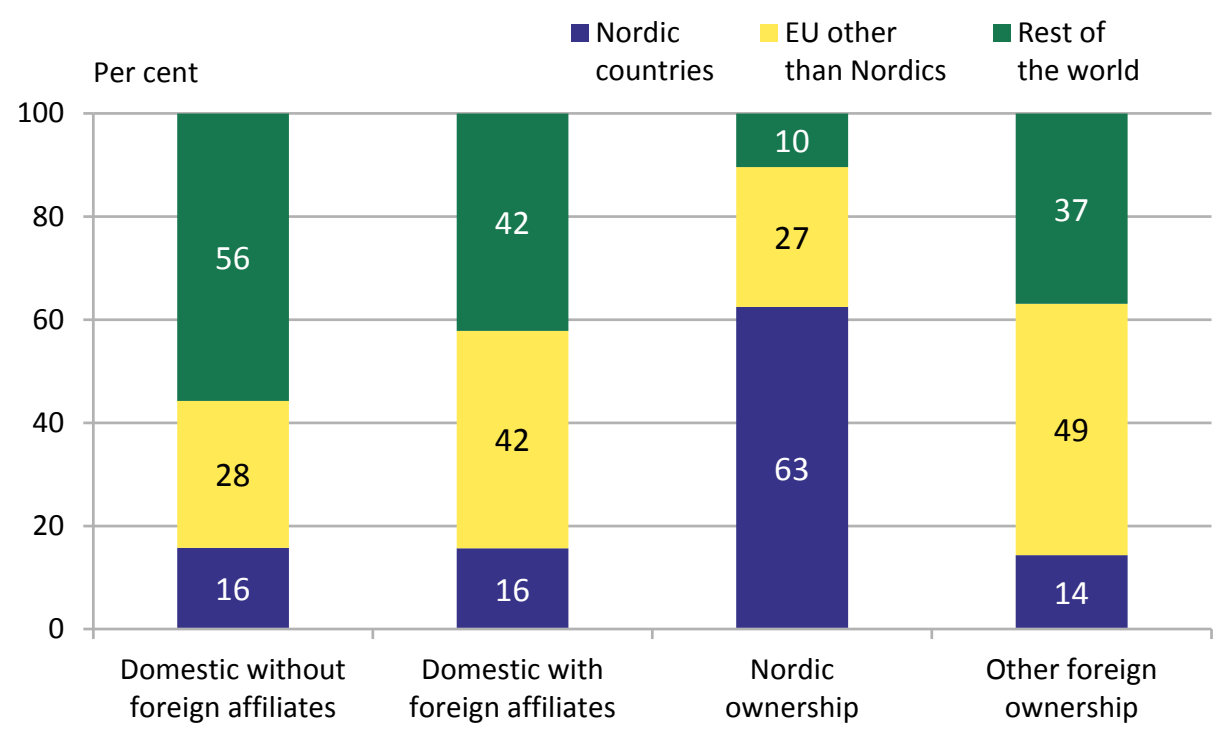

Note: Export markets, which are unknown in the dataset, are excluded.

Source: National services trade surveys linked with statistical business registers. See Annex 1.3 for a more detailed description.

As mentioned above, a large share of Swedish exports is executed by foreign owned enterprises. The majority of these exports go to large EU countries, which may indicate that the investment is a way to secure a location in an EU country and thus being part of the internal market. 



\section{Performance of exporters and non-exporters of goods}

\section{Main findings}

- Goods exporting enterprises contribute significantly to employment and value added in the Nordic countries. Exporters are most important in Denmark, accounting for $27 \%$ of employment in the non-financial market sector and $32 \%$ of total gross value added in 2014 .

- Exporters in manufacturing account for a very high share of the total exports of goods from each of the Nordic countries, and they also account for the majority of employment within manufacturing, except in Norway. Since 2008, however, exporting enterprises in manufacturing lost more jobs than the non-exporting enterprises in Denmark, Finland and Sweden. The opposite development can be observed for Norway. In total, the exporting manufacturing enterprises in these four Nordic countries lost more than 200,000 full time employees in the period 2008 to 2014 - or $20 \%$ of total employment in manufacturing exporters in 2008.

- The exporting enterprises are more productive than the non-exporting enterprises within manufacturing. In Denmark, Finland, Norway and Sweden the gross value added generated per employee is considerably higher for exporters than non-exporters. Furthermore, in all four countries the value added per employee in exporting enterprises developed more positively than in the nonexporting ones, in particular in Denmark.

- The geographical pattern of exports is relatively similar across the Nordic countries. Around $15 \%$ of manufacturing exports go to the Nordic region, while the remaining EU constitutes the largest market area with 44 to $49 \%$ of total manufacturing exports from the Nordic countries.

\subsection{Importance of goods exporting enterprises}

The importance of the goods exporting enterprises for the national economies differs quite substantially across the Nordic countries although they all can be characterised as small open economies. 


\section{Exporting enterprises}

In the analysis based on linked micro data, the exporting enterprises are defined as those enterprises whose annual exports have a value of at least EUR 5,000 and account for at least $5 \%$ of the enterprise's turnover. The exports of goods from enterprises that do not meet these criteria generally account for $2-3 \%$ of the total value of goods exports.

The definition is in part based on Eurostat's recommended threshold of EUR 5,000 of exports for an enterprise to be considered an exporting enterprise. The argument for applying such a threshold definition is this improves the analysis by cleaning up the category of exporters so that only those that are indeed internationally oriented and for whom exports are relevant in relation to the enterprise's characteristics are included-as opposed to enterprises that may occasionally sell e.g. used machinery to another company abroad.

In relative terms, exporters are of most importance in Denmark as the 12,100 exporting enterprises constitute nearly $6 \%$ of all enterprises, employing 309,400 full time equivalent employees (FTE) or $27 \%$ of the total number of full time employment in the nonfinancial market sector and created EUR 40 billion in gross value added - or $32 \%$ of total gross value added in 2014, cf. figure 52.

Figure 52: Exporters' share of employment (FTE) and gross value added. 2014

\footnotetext{
Per cent
}

40

Per cent

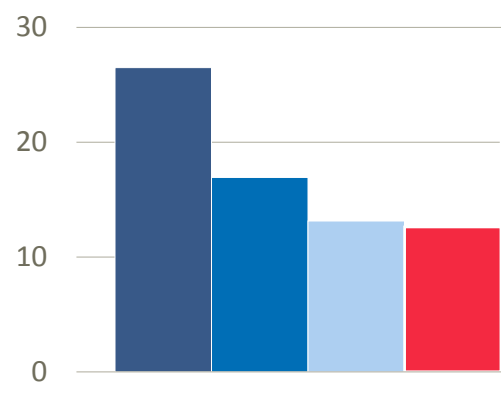

Employment (FTE)

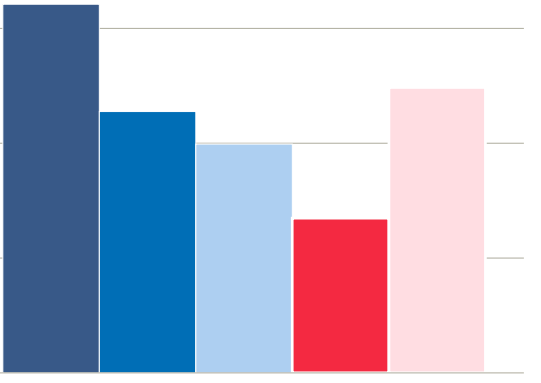

Gross Value Added

Denmark $\quad$ Finland Iceland Norway $\quad$ Sweden

Source: Statistics Denmark, Finland, Iceland, Norway and Sweden; national database on non-financial business sector linked with international trade in goods statistics. For a description of data sources and national databases, see Annex. 
At the other end, we find Finland where the 3,60o goods exporting enterprises only accounted for $1 \%$ of total number of enterprises, but employed $219,500 \mathrm{FTE}-$ or $17 \%$ of the total number of full employees - and only $23 \%$ of total value added; close to EUR 22 billion.

The exporting enterprises are in general relatively large; especially in Finland with 61 full-time employees per enter-prise, while the Danish exporting enterprises are significantly smaller (26 full-time employees per enterprises), see figure 53 .

Figure 53: Size of exporting enterprises (average FTE per enterprise). 2014

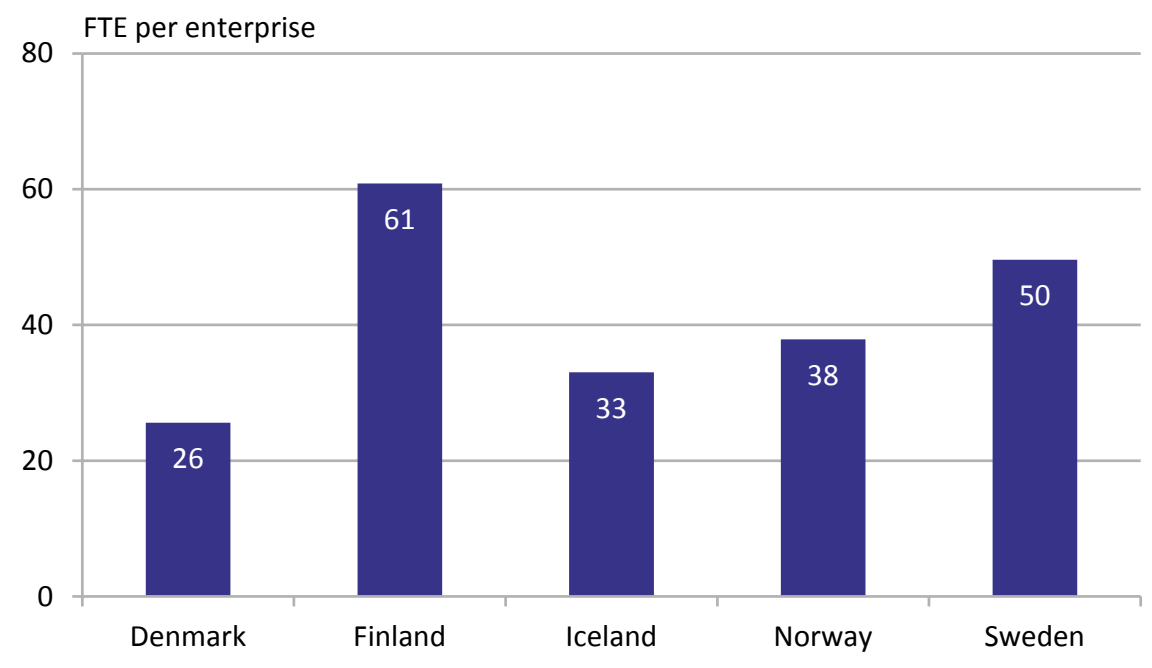

Source: Statistics Denmark, Finland, Iceland, Norway and Sweden; national database on non-financial business sector linked with international trade in goods statistics, cf. Annex.

The Danish exporting enterprises on the other hand create a large value added (EUR 129,000 per FTE) only exceeded by the Norwegian enterprises (EUR 175,000), while Sweden (EUR 111,000) and Finland (EUR 100,000) cluster at the other end, see figure 54. The value added per FTE is considerably higher for the exporting enterprises than for the non-exporting ones in all five countries. In Denmark, the exporting enterprises generated a gross value added per FTE that was $31 \%$ higher than the non-exporters in 2014. The corresponding figures for the other Nordic countries are $44 \%$ in Finland, $64 \%$ in Iceland, $8 \%$ in Norway, and $28 \%$ in Sweden. 
Figure 54: Value added per FTE in exporting enterprises. 2014

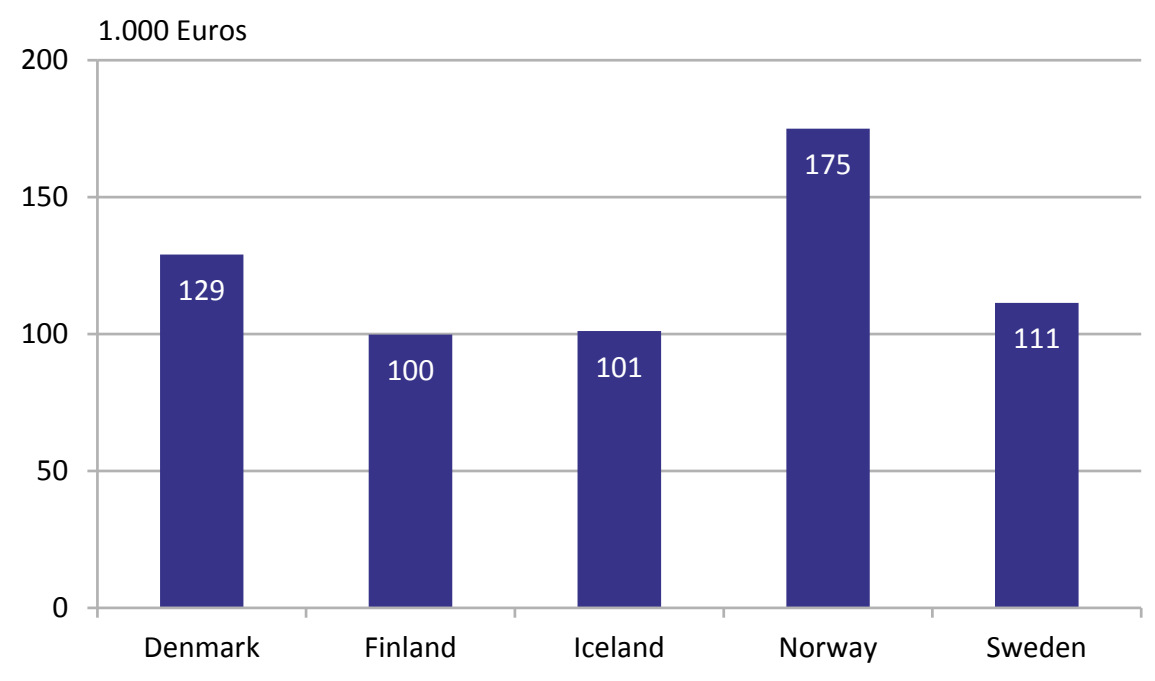

Source: Statistics Denmark, Finland, Iceland, Norway and Sweden; national database on non-financial business sector linked with international trade in goods statistics, cf. Annex.

Although the importance of exporting enterprises differs across the Nordic countries, the development since the economic crisis started in 2008 is more similar. In all Nordic countries we can observe a decrease in the number of employees in the exporting enterprises since the crisis - except for Norway and Iceland, cf. figure 55. A similar development can be found when looking at the value added creation, only that Norwegian exporters experienced the largest decline while Icelandic and Swedish exporters experienced a moderate increase.

For Denmark and Finland employment showed a larger decline than value added for the exporters implying a productivity growth - measured as gross value added created per employee - in the period 2008 to 2014 . The productivity growth for the exporting enterprises has been larger than for the enterprises only serving the domestic markets in Finland and Sweden, while the opposite development can be observed for Denmark and Norway. 
Figure 55: Development in employment (FTE) and gross value added. Exporters and non-exporters. 2014

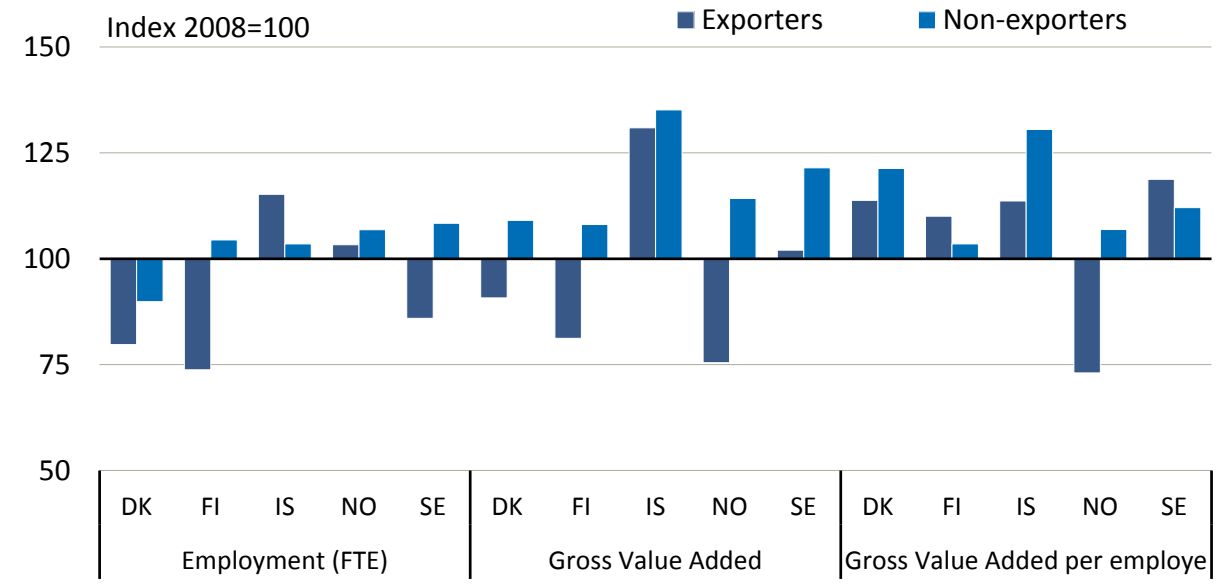

Source: Statistics Denmark, Finland, Iceland, Norway and Sweden; national database on non-financial business sector linked with international trade in goods statistics, cf. Annex.

Not surprisingly, the majority of the goods are exported from manufacturing enterprises - although substantial differences across the Nordic countries can be observed. The Finnish exports of goods are dominated by manufacturing while exports to a much larger extent are channelled via wholesaling enterprises in especially Denmark, and to a lesser extent in Norway and Sweden, cf. figure 56.

Figure 56: Exports of goods by industry

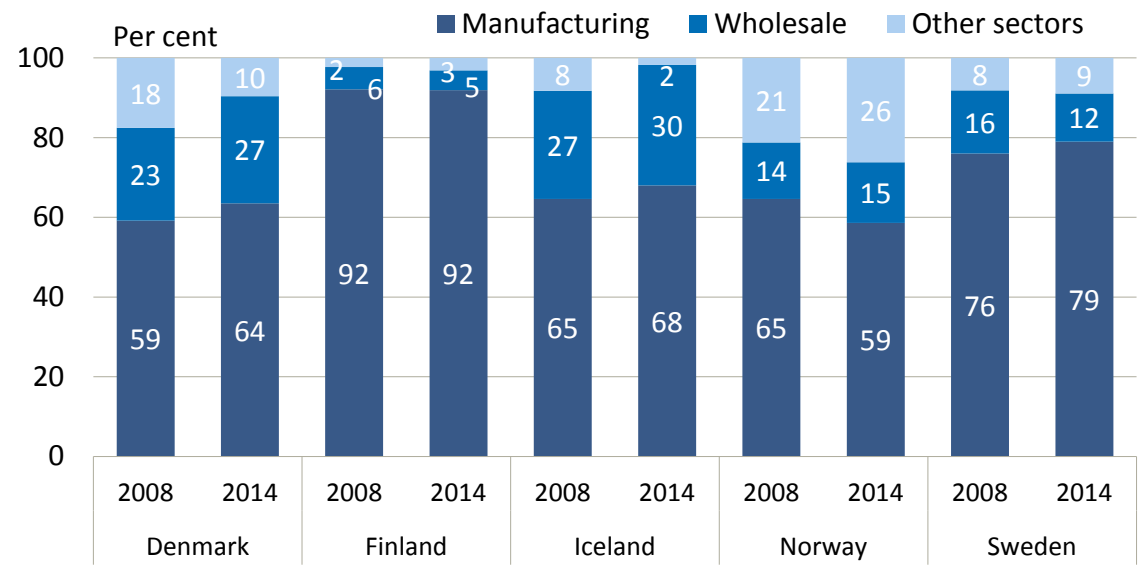

Source: Statistics Denmark, Finland, Iceland, Norway and Sweden; national database on non-financial business sector linked with international trade in goods statistics, cf. Annex. 
The Finnish exports are fairly concentrated even within manufacturing, traditionally in large enterprises within the electronics industry, in high value added processing of metals, the chemical industry and paper mills that produce pulp and paper. Part of the explanation for the Finnish results is also that there is a discrepancy between the Customs Office data and the SBS data, as the linking between these sources at enterprise level eliminates a number of observations that are not included in the SBS.

\subsection{Exporting enterprises in manufacturing}

The previous section presented results for all enterprises in the non-financial market sector but as the focus is on goods exporting enterprises, this section only analyses manufacturing enterprises. When doing so, we find different developments across the Nordic countries as the exporting enterprises in Denmark, Finland and Sweden account for considerably more than half of employment within manufacturing - and for $43 \%$ of employment in both Iceland and Norway, see figure 57 . In all the Nordic countries, exporters' share of value added is even higher.

Access to foreign markets and thus increased export opportunities is a major factor for job creation for small economies as the Nordic ones. But on the other hand, the dependency of foreign markets also makes the exporting enterprises more vulnerable towards shocks caused by international business cycles. The period since 2008 is certainly not a period where job growth took place and it is characteristic that the exporting enterprises in manufacturing lost more jobs than the non-exporting ones in Denmark, Finland and Sweden. The opposite development can be observed for Norway. In total, the exporting enterprises in these four Nordic countries lost more than 200,000 FTE in the period 2008 to 2014 - or $20 \%$ of total employment in manufacturing exporters in 2008. In absolute figures, manufacturing exporters in Sweden experienced the largest decline of 74,000 full time employees, followed by 68,000 fewer full time employees in Finland and 59,000 in Danish manufacturing enterprises. 
Figure 57: Exporters' and non-exporters' share of employment (FTE) and value added (GVA). Manufacturing. 2014

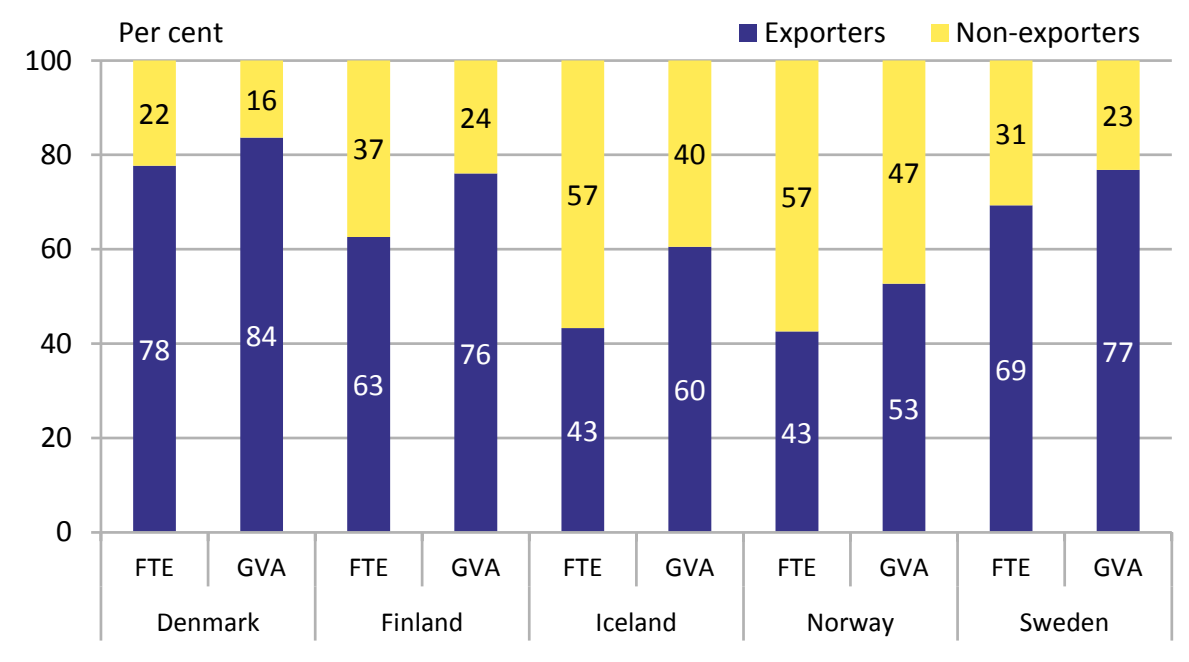

Source: Statistics Denmark, Finland, Iceland, Norway and Sweden; national database on non-financial business sector linked with international trade in goods statistics, cf. Annex.

The exporting enterprises are more productive than the non-exporting enterprises within manufacturing. In Denmark, Finland, Norway and Sweden the gross value added generated per employee is considerably higher for exporters than non-exporters. 
Figure 58: Gross value added per employee. Manufacturing 2014

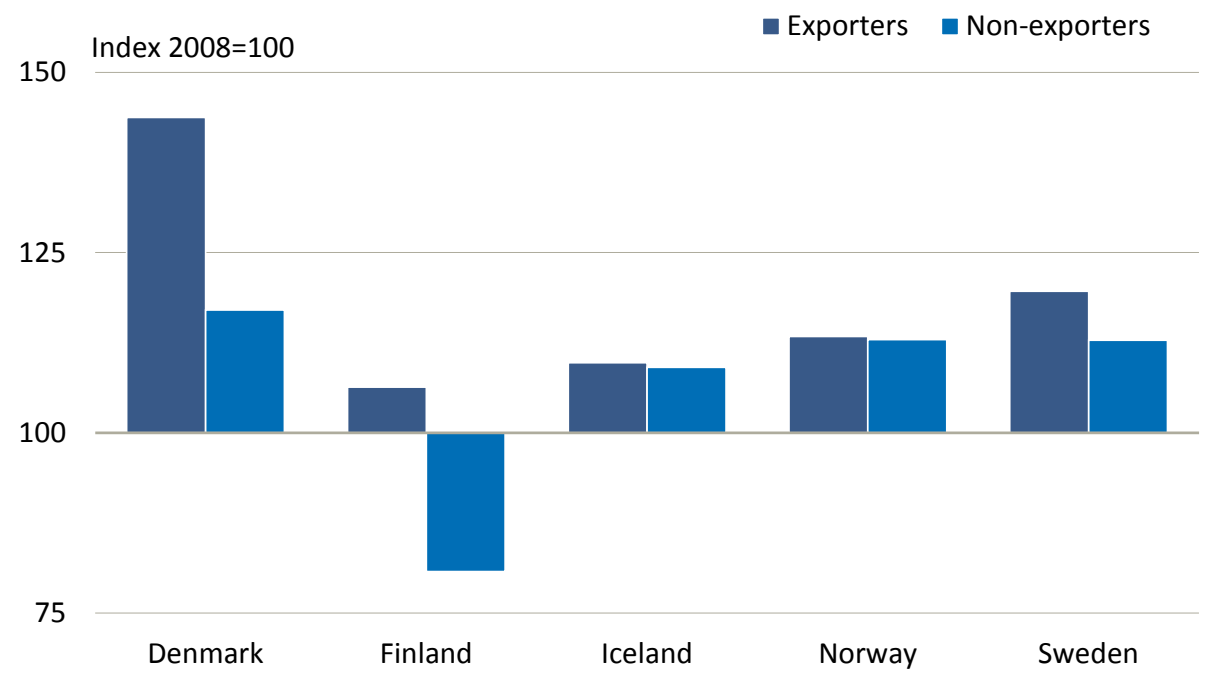

Source: Statistics Denmark, Finland, Iceland, Norway and Sweden; national database on non-financial business sector linked with international trade in goods statistics, cf. Annex.

Furthermore, in all four countries the value added per employee in exporting enterprises developed more positively than the non-exporting ones, in particular in Denmark see figure 58 . These results are in line with the literature which finds that enterprises competing internationally are more productive than the ones only selling domestically. ${ }^{24}$

24 Wagner, Joachim: Exports and productivity: a survey of the evidence from firm-level data. The World Economy (2007) 30.1: $\mathrm{pp} 60-82$. 
Figure 59: Exports intensity. Exporters in manufacturing

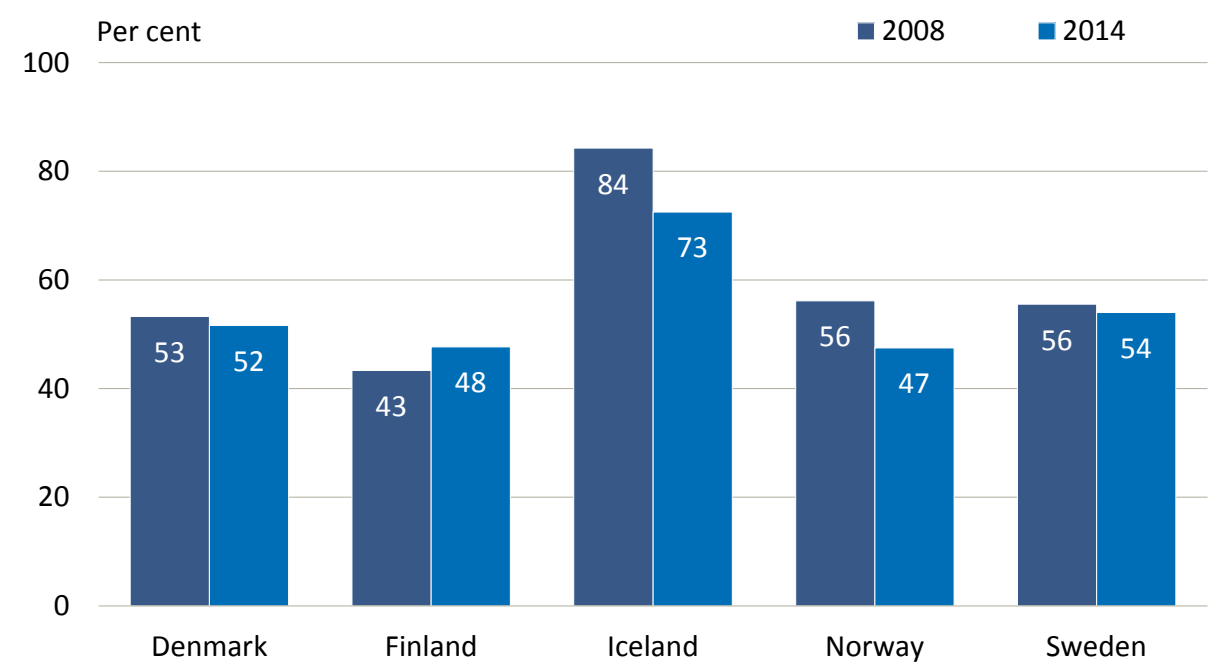

Source: Statistics Denmark, Finland, Iceland, Norway and Sweden; national database on non-financial business sector linked with international trade in goods statistics, cf. Annex.

Export intensity describes share of the turnover that comes from exports, and it can be seen as an indicator of the degree of involvement in foreign trade. In general, with an export intensity of around 50\% - for Danish and Swedish manufacturing enterprises even more - exports for the Nordic manufacturing enterprises is important, although the export intensity has decreased in the period in all Nordic countries except Finland, cf. figure 59 .

The geographical pattern of exports is relatively similar across the Nordic countries with the Nordic countries constituting around $15 \%$ of the exports from the manufacturing sector for all countries.

The other $25 \mathrm{EU}$ member states constitute the largest market area 44 to $49 \%$ of total exports from the Nordic countries. These two destinations account for close to two thirds of total exports from manufacturing in all the Nordic countries except for Finland which is characterised by a relatively larger share of exports going to non-European markets (around 40\%), especially to Russia. 
Figure 60: Exports by geographical destination. Exporters in manufacturing

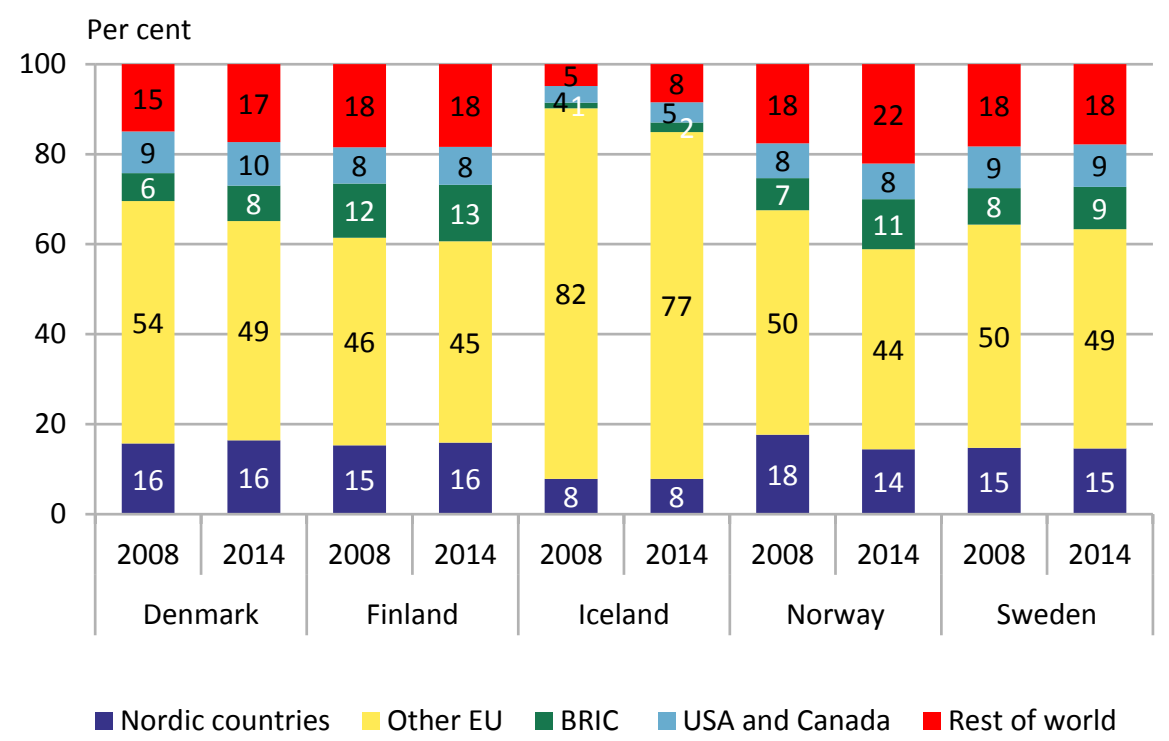

Source: Statistics Denmark, Finland, Iceland, Norway and Sweden; national database on non-financial business sector linked with international trade in goods statistics, cf. Annex.

For Finland, Denmark and Norway the by far most important Nordic market is Sweden - only for Iceland Sweden is not particularly important as an export destination. In the case of Sweden, Norway is the most important Nordic market accounting for nearly half of all Swedish exports of goods to the other Nordic countries. 
Figure 61: Manufacturing sector's exports of goods to other Nordic countries

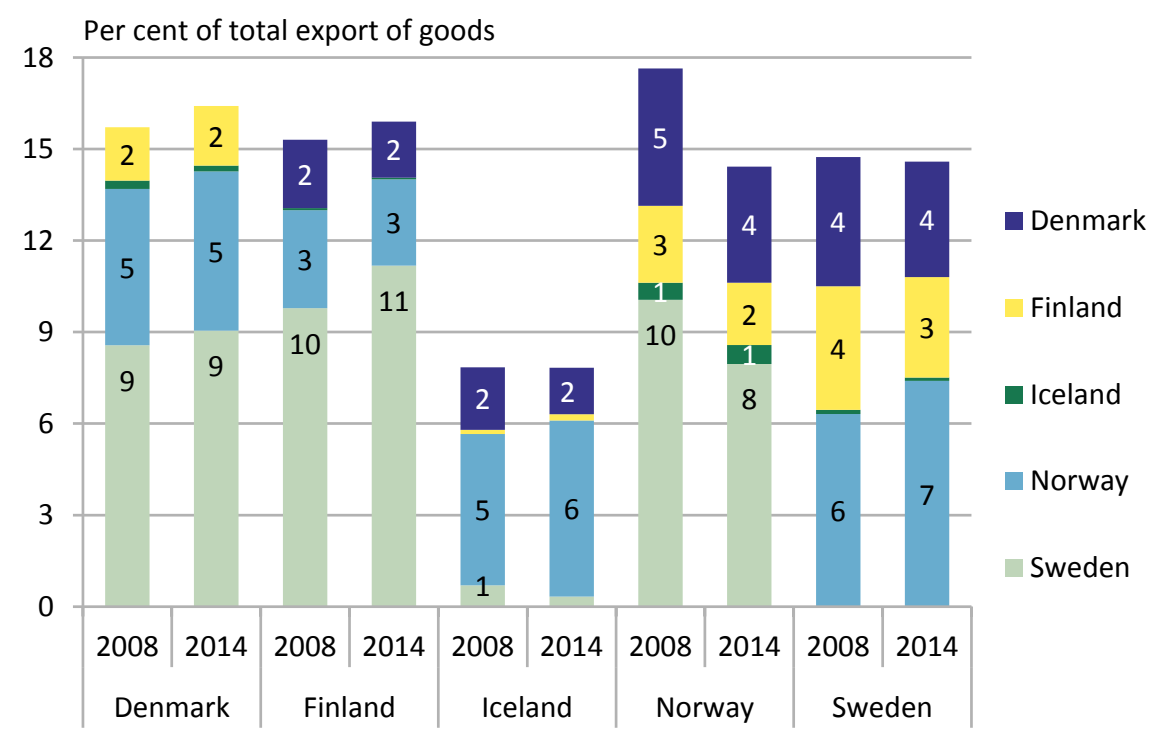

Source: Statistics Denmark, Finland, Iceland, Norway and Sweden; national database on non-financial business sector linked with international trade in goods statistics, cf. Annex. 



\section{Performance of different types of SMEs}

\section{Main findings}

- Small and Medium sized Enterprises (SMEs) are normally seen as important vehicles for economic growth and job creation, and in enterprise policy shaping this often combines with an assumption that SMEs come with a considerable export potential. In this analysis, we use new data and refine the traditional statistical definition of SMEs (based on employment within the enterprise itself), taking into account enterprise group dependency and external ownership relations to focus on independent SMEs, dependent SMEs, large group SMEs and large enterprises.

- In all Nordic countries, independent SMEs make up the vast majority of enterprises and also account for more than half of total SME employment. However, large group SMEs, which account for less than $5 \%$ of all SMEs, account for around one third of total SME employment in the Nordics. The same pattern is found when looking at gross value added. Furthermore, large group SMEs are especially important when it comes to exports, accounting for more than two thirds of total SME exports in Finland and for half in Denmark.

- This new type of breakdown of SMEs is important for policy shaping because a considerable share of SME exports actually stems from these large group SMEs, which should more rightly be considered as large enterprises, given their affiliation with other enterprises within the (large) group. Put another way, the importance of "true" SMEs for exports for the Nordic enterprises diminishes further as they only account for $26 \%$ of total exports of goods in Denmark, $20 \%$ in Norway, and $12 \%$ in Finland and Sweden. 


\subsection{Small and Medium sized Enterprises and growth}

Small and Medium sized Enterprises (SMEs) are in the literature described as a key driver for economic growth and job creation. ${ }^{25}$ SMEs are also in focus for enterprise policy shaping, where they are seen to have a huge and unexploited export potential. ${ }^{26}$

This is the reason for the focus on SMEs in this chapter, but based on a new data material we have refined the traditional statistical definition of SMEs from only being based on the employment size, i.e. enterprises with less than 250 persons employed, to also include information about dependency and external ownership as being part of an enterprise group.

\section{Enterprise group affiliation}

Enterprises are placed in two main categories, depending on whether the enterprises have group affiliations with one or more enterprises or not. Based on this, the analysis distinguishes between two groups:

- Independent enterprises are not part of an enterprise group in the reporting country, e.g. in Denmark. The data sources do not contain information on ownership relations in other countries meaning that an affiliate of a foreign enterprise group will appear as an independent enterprise in this analysis, just as domestic group head which only has affiliates abroad will also appear as an independent enterprise here.

- Dependent enterprises are part of an enterprise group in the reporting country, e.g. in Denmark, being either an affiliate or a resident group head.

Affiliation is determined on the basis of controlling influence, i.e. the control of $50 \%$ of stocks/votes.

Based on these two main categories, it is possible to separate the SMEs into two groups. To take the analysis even further, however, it is useful to further distinguish between those SMEs that are affiliated with a large enterprise group - and those that are affiliated with a group that, counting the total employment in the group in the reporting country would still be considered within the SME range, i.e. employment being less than 250 FTEs.

\footnotetext{
25 Inspired by Birch, David L.: The job generation process (1979) there exists a vast literature on the issue of the contribution of SMEs to job creation, see for instance Henrekson, Magnus and Johansson, D: Gazelles as job creators: a survey and interpretation of the evidence. Small Business Economics (2010), Vol. 35:2, pp 227-254.

${ }^{26}$ In all Nordic countries as in the European Commission, dedicated export agencies have been established with the purpose of supporting especially the export opportunities of SMEs, see for instance Det handler om arbejdspladser: Eksportrådets politik for små og mellemstore virksomheder (Copenhagen: Danish Ministry of Foreign Affairs, 2014).
} 
The illustration below shows how these categorisations combine into new analytical categories which are used in the following:

1. Independent SMEs: SMEs that are not affiliated to a domestic group, and which are not foreign controlled.

2. SMEs belonging to a domestic SME group: Dependent SMEs that are affiliated to other domestic enterprises, but where the employment in the domestic enterprise group is less than 250 FTEs.

3. Large group SMEs: Dependent SMEs that are affiliated to other domestic enterprises, where the employment in the domestic enterprise group is at least 250 FTEs, or which are foreign controlled.

4. Large enterprises: Large enterprises with employment of 250 FTEs or more are grouped together regardless of group affiliation and nationality of ownership.

Figure 62: Analytical categories of enterprises

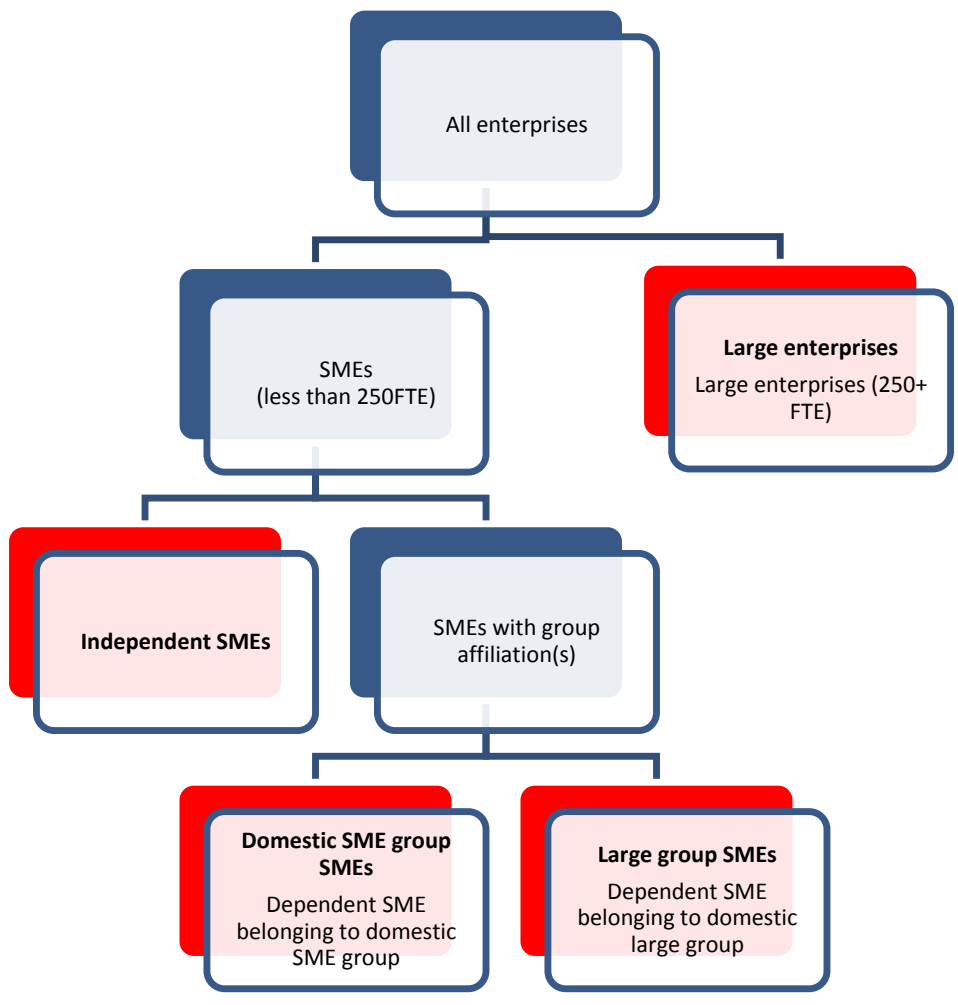


SMEs are dominant when it comes to employment or value added, as the SMEs account for close to two thirds of total employment in the non-financial market activities - from $73 \%$ in Iceland to $65 \%$ in Norway. When it comes to value added the same pattern can be found, from $72 \%$ in Norway to $63 \%$ in Denmark, Finland and Sweden. Concerning exports, the main part of the total exports of goods in all Nordic countries comes from the large enterprises with 250 or more employees. The large enterprises in Sweden and Finland account for $66 \%$ of total exports of goods, followed by Norway $(60 \%)$, Iceland $(57 \%)$ and Denmark (52\%).

Figure 63: Total employment, Gross Value added and exports broken down by enterprise size. 2014

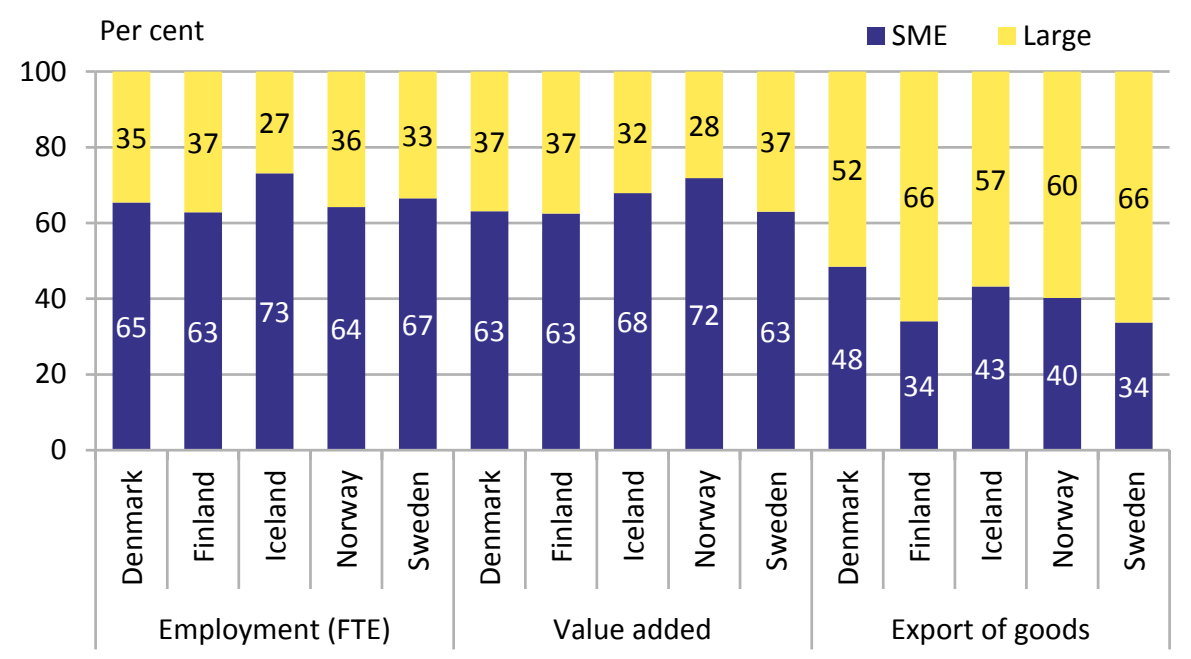

Source: Statistics Denmark, Finland, Iceland, Norway and Sweden; national database on non-financial business sector linked with international trade in goods statistics, cf. Annex.

In all Nordic countries, the SMEs with no group affiliation (hereafter named independent SMEs) dominate - from $95 \%$ of all SMEs in Finland to $76 \%$ in Denmark, see figure 64. But the pattern is different if we look at the importance of the different types of SMEs in terms of employment, gross value added and exports, see figure 65 . In terms of employment, the independent SMEs are still the largest group with just above half of total employment in SMEs, from employing 0.6 million full time employees out of totally 1.2 million full time employees in SMEs in Denmark to employing 1.2 million out of 2.3 million full time employees in SMEs in Sweden.

It is notable, that the SMEs, belonging to large or foreign owned groups, which only account for less than $5 \%$ of all SMEs in the Nordic countries, account for a considerable 
part of employment, around one third of total employment in SMEs in the Nordic countries. The same pattern can be found when looking at gross value added. The SMEs, belonging to large groups or foreign owned, are of especial importance for the exports from SMEs as they account for more than two thirds of total exports from SMEs in Finland (total SME exports amounting to EUR 49.5 billion in 2014) and Sweden (EUR 106.6 billion in total) and for half of the exports from SMEs in Denmark (EUR 74.3 billion).

Figure 64: Share of (number of) SMEs by group affiliation status. 2014

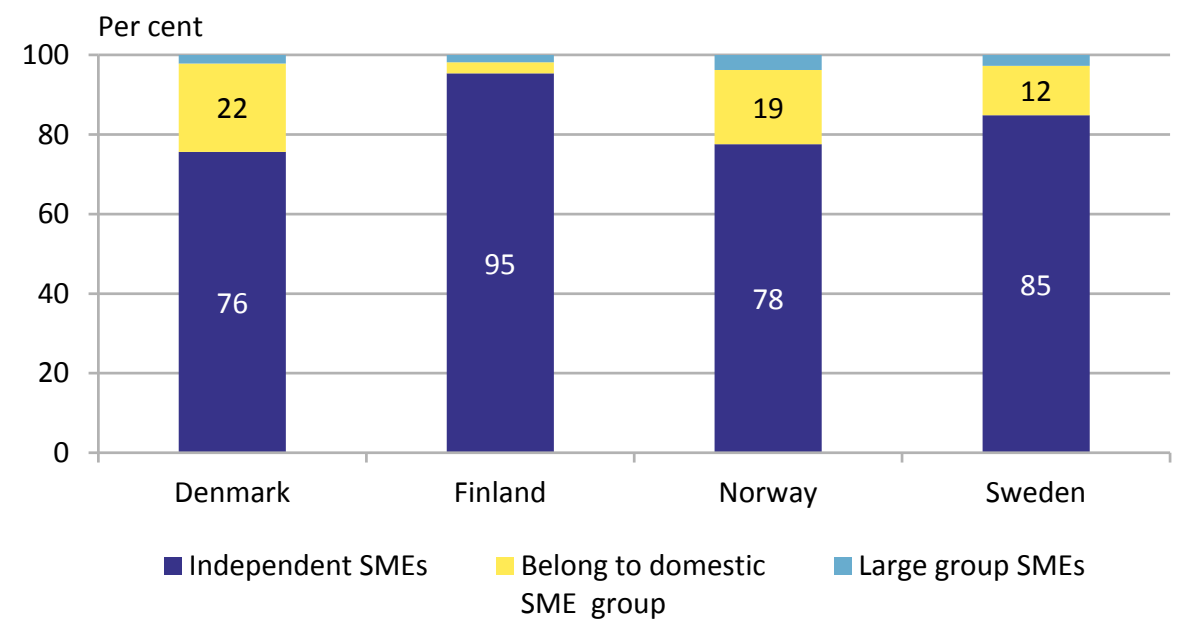

Note: No data available for Iceland.

Source: Statistics Denmark, Finland, Iceland, Norway and Sweden; national database on non-financial business sector linked with international trade in goods statistics, cf. Annex.

This new type of breakdown of SMEs by type of dependency shows very interesting results for policy shaping as between half and two thirds of the exports from SMEs in the Nordic countries can be attributed to SMEs belonging to large groups with more than 250 employees or to foreign groups. These SMEs could more rightly be classified as large enterprises as they can be expected to benefit from different types of economies of scale, for instance easier access to finance, foreign markets or specific professional skills than independent SMEs due to the affiliation with other enterprises within the group.

Building on these results, the importance of "true" SMEs for exports for the Nordic enterprises diminishes further as they only account for $26 \%$ of total exports of goods in Denmark, 20\% in Norway, $12 \%$ in Finland and Sweden. 
Figure 65: Employment, gross value added and exports of goods. By size class-group affiliation status. 2014

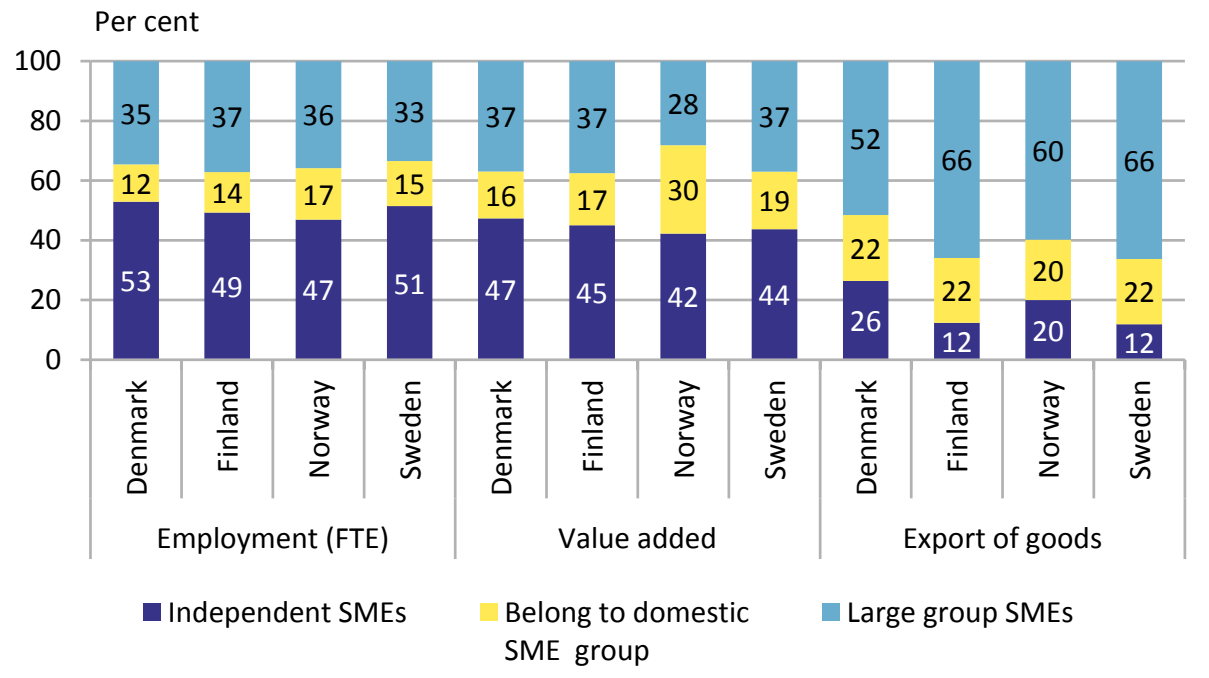

Note: No data available for Iceland.

Source: Statistics Denmark, Finland, Iceland, Norway and Sweden; national database on non-financial business sector linked with international trade in goods statistics, cf. Annex.

Looking at the development in productivity by type of SME, the SMEs belonging to large groups show the highest productivity growth measured as gross value added per full time employee in the period 2009 to 2014 in all Nordic countries; although the increase is very different from country to country, cf. figure 66. In Denmark the highest growth (32\%) can be observed followed by Sweden (20\%). As the SMEs belonging to large groups also to a large extent are the ones exporting compared with the other SME groups, this finding fits well with the previous finding of the higher increase in productivity of exporting enterprises in general compared to the non-exporting ones.

Looking at the absolute values for the SMEs belonging to large groups Norway shows the highest productivity per employee (EUR 128,800), followed by Denmark (EUR 113,700) and Sweden (EUR 101,600), while Finland showed a considerable lower productivity level (EUR 75,000). It should be stressed that the dependent SMEs belonging to groups with less than 250 FTE are the most productive ones - EUR 281,600 per FTE in Norway, EUR 134,100 per FTE in Denmark and EUR 118,500 per FTE in Sweden. 
Looking at the export performance (right-hand side of figure 66), the level for the SMEs belonging to large groups is different across the Nordic countries. Denmark shows the highest export value per full time employee (EUR 94,000), followed by Sweden (EUR 92,900) and Finland (EUR 68,000).
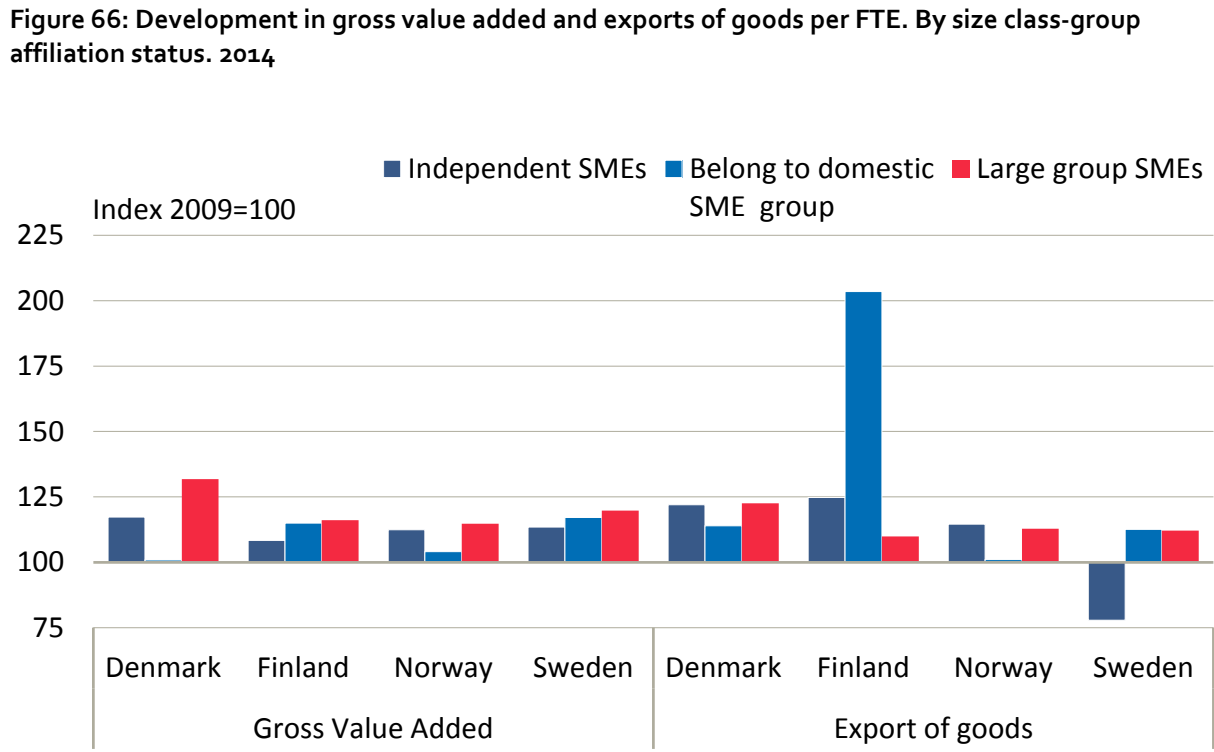

Note: No data available for Iceland. The index value for gross value added per FTE for the Danish Dependent SMEs in 2014 is 100.9, and for the Norwegian Dependent SMEs it is 101.0. They are included in the figure above, even if they are not visible.

Source: Statistics Denmark, Finland, Iceland, Norway and Sweden; national database on non-financial business sector linked with international trade in goods statistics, cf. Annex.

The pattern across SME types is also different as the dependent SMEs belonging to a small group in Denmark shows the largest export value per full time employee (EUR 112,400 ) as well as in Finland (EUR 61,100), while this SME type ranks second in Sweden (EUR 68,000) after the SMEs belonging to large groups. This pattern fits well to the development in total exports in the period 2009 to 2014 as the dependent SMES shows the largest increase in Denmark (34\%) while the SMEs belonging to large groups show the largest growth in Norway (35\%), see figure 67. 
The heterogeneity of SMEs clearly influences the geographical spread of exports. Although not surprisingly, the other EU countries are the largest market for all SMEs independent of group status - in all Nordic countries, especially independent SMEs and SMEs belonging to small groups have a relative large share of their exports going to the other Nordic countries.

Figure 67: Export development. Size class-group affiliation status. 2014

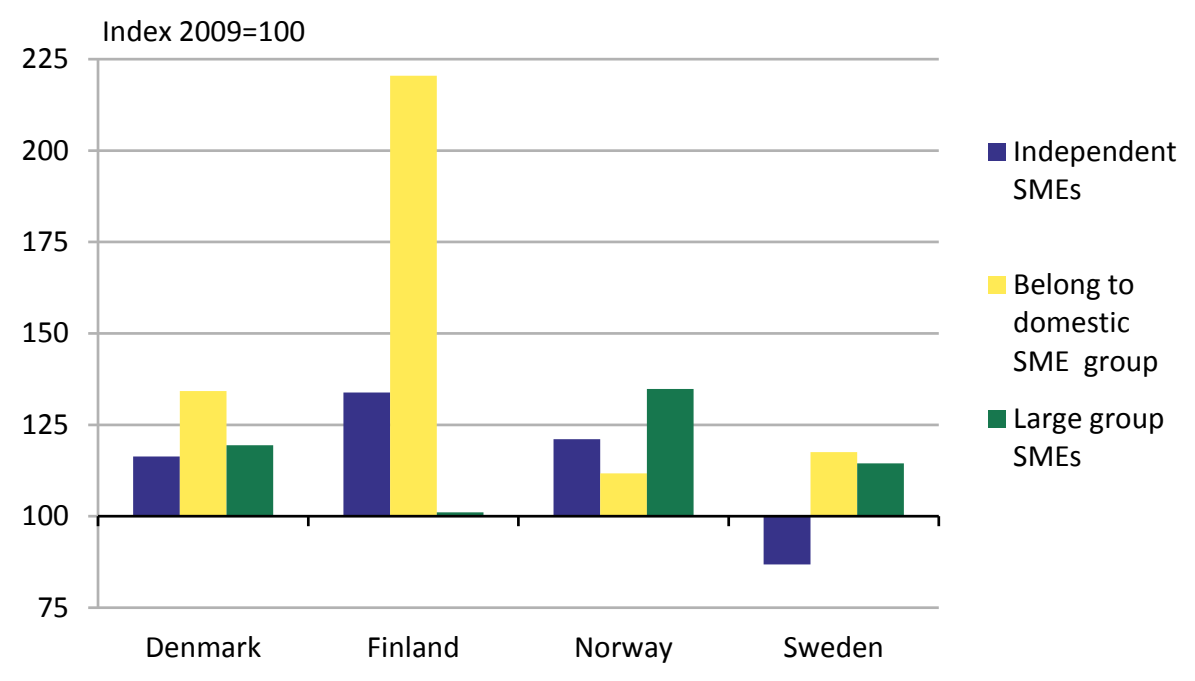

Note: No data available for Iceland.

Source: Statistics Denmark, Finland, Iceland, Norway and Sweden; national database on non-financial business sector linked with international trade in goods statistics, cf. Annex.

This is especially the case for Swedish SMEs (around one third of total exports for these groups); Finland being the only exception from this pattern. 


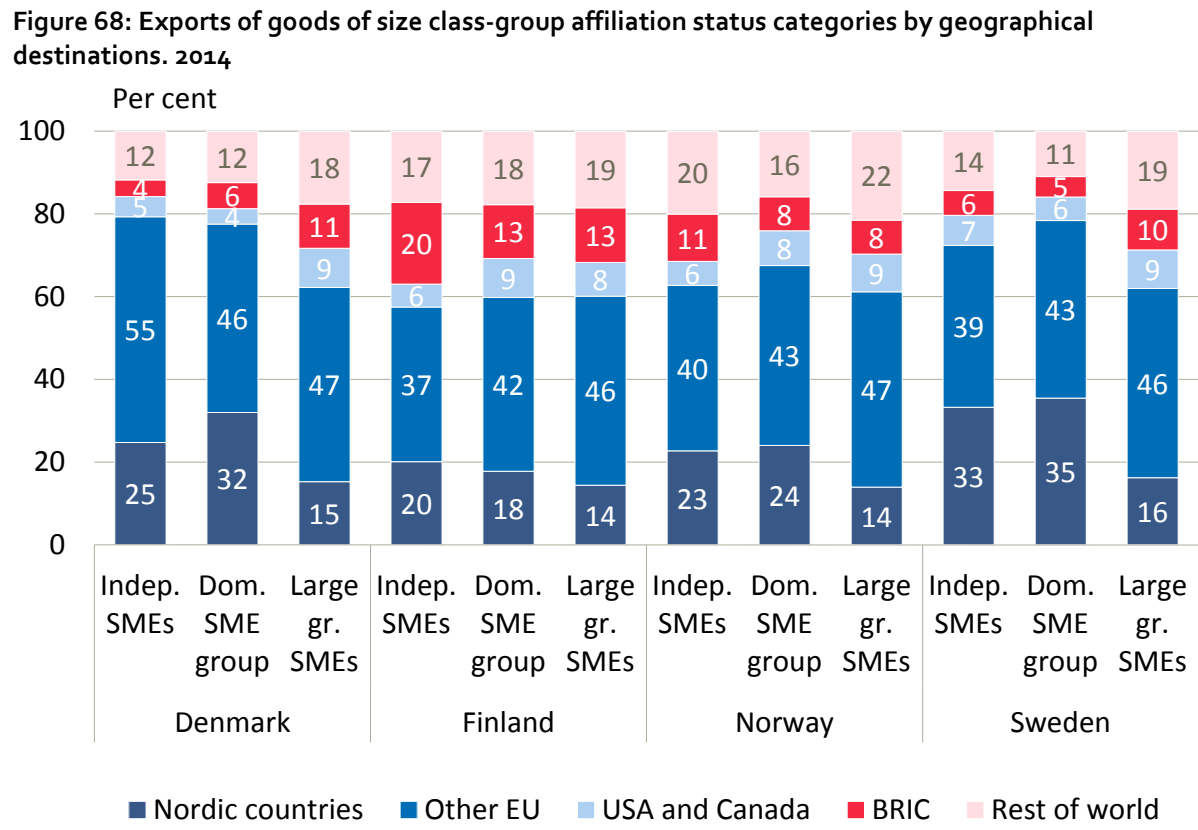

Note: No data available for Iceland.

Source: Statistics Denmark, Finland, Iceland, Norway and Sweden; national database on non-financial business sector linked with international trade in goods statistics, cf. Annex. 



\section{Performance of domestically and foreign owned enterprises}

\section{Main findings}

- This chapter focuses on different types of firms (firm heterogeneity) in terms of nationality of ownership, distinguishing between domestically and foreign owned enterprises, and further between domestically owned enterprises with or without foreign affiliates.

- Focusing on manufacturing, there is a varied picture across the Nordic countries as more than half of the goods exports from Sweden comes from foreign owned enterprises, with significantly lower shares in both Denmark and Finland. Danish exports are characterised by the high share of exports from domestically controlled multinational enterprises (MNEs), due to the predominantly Danish ownership within key strongholds such as pharmaceutical products and windmills, while in Finland the domestically owned enterprises without foreign affiliates account for nearly half of manufacturing exports.

- Perhaps surprisingly, the geographical distribution of the exports of foreign owned enterprises is not markedly different from that of the domestically owned enterprises. The only slight difference is a somewhat larger share of exports from foreign owned enterprises going to the BRIC markets, possibly indicating an integration into globally highly dispersed organisation of production by MNEs.

\subsection{Ownership and performance}

Based on the micro level data established for this project, it is possible to analyse different types of firms. Focus in this chapter is on types of ownership, which is one of the characteristics that are considered to be of special importance for globalisation and firm. ${ }^{27}$

Type of ownership is defined in the first instance by nationality of ownership - being domestically or foreign controlled - and, secondly, for domestically controlled enterprises by their presence abroad - having foreign affiliates or not. The reason for the latter group

${ }_{27}$ Fetzer, James J. and Strassner, Erich H.: Identifying Heterogeneity in the Production Components of Globally Engaged Business Enterprises in the United States. Bureau of Economic Analysis (2015). 
is that multinational enterprises - being domestically or foreign controlled - can be considered having the same opportunities of utilising access to production factors abroad, being labour, knowledge, capital or markets, to optimise the production process and obtain efficiency gains as opposed to enterprises that are domestically controlled and only acting on the domestic market or via arms-length trade.

Figure 69: Exports of goods by ownership category

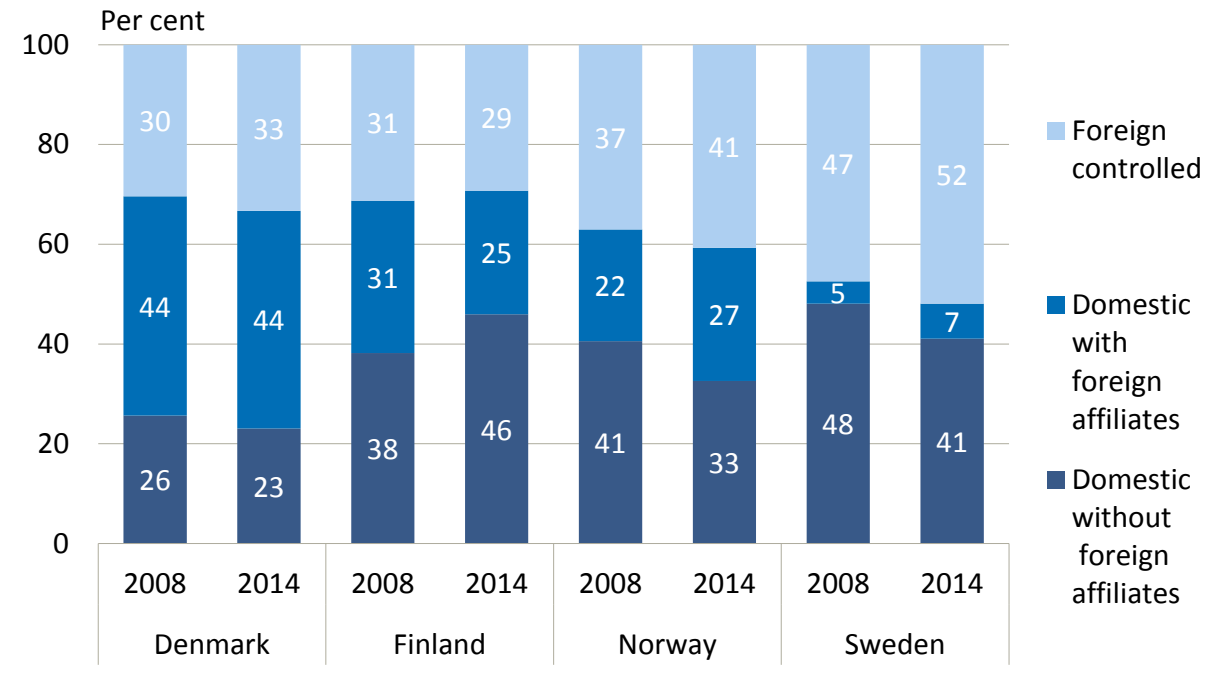

Note: No data available for Iceland.

Source: Statistics Denmark, Finland, Iceland, Norway and Sweden; national database on non-financial business sector linked with international trade in goods statistics, cf. Annex.

The export patterns differ across the Nordic countries as the majority of the exports from Sweden is exported by foreign controlled enterprises (52\%) compared to $41 \%$ in Norway, $33 \%$ in Denmark and only $29 \%$ in Finland, see figure 69 . Finland is characterised by the fact that nearly half of all exports is from domestically owned enterprises without foreign affiliates while in Denmark the largest share of exports comes from the domestically owned enterprises with foreign affiliates.

These patterns should be seen in the context of the national strongholds. For example, the Danish stronghold of pharmaceuticals mainly is produced and exported by Danish owned companies with foreign affiliates while the Swedish stronghold of road vehicles has a high share of foreign owned producers.

The development since the crisis is similar in Denmark and Sweden as the foreign owned enterprises in both countries have increased their share of total exports of goods from 2008 to 2014, while we see a decrease in Finland in the same period. 
Figure 70: Development in value added and exports of goods per FTE. By ownership category.2014

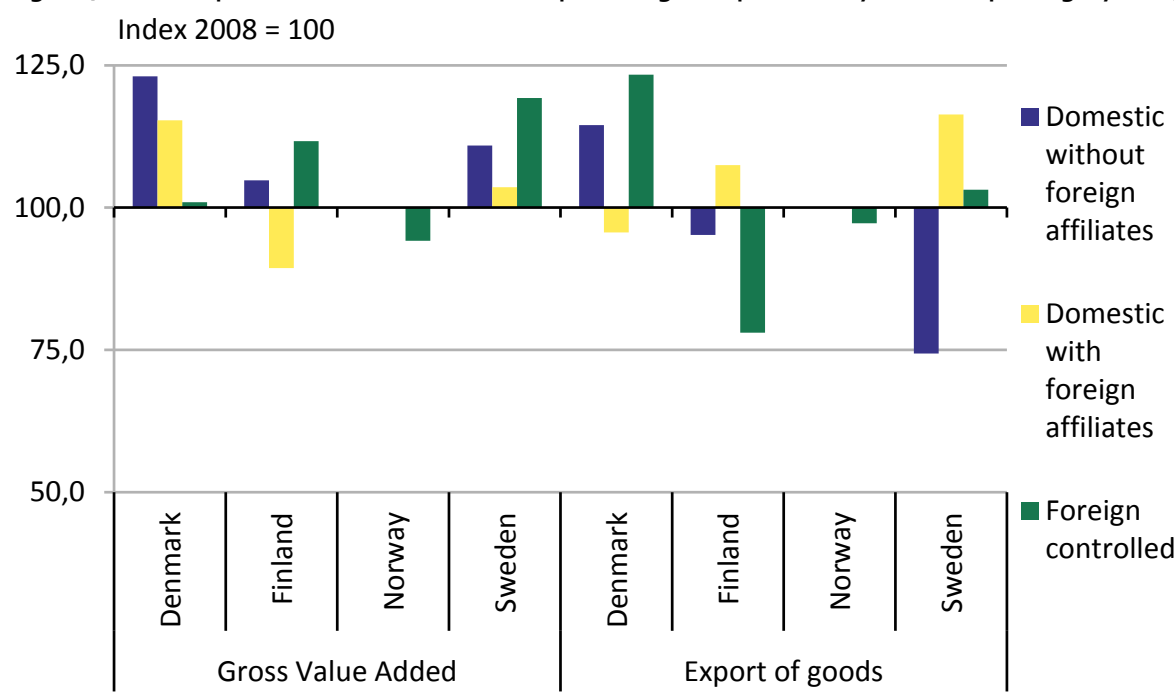

Note: No data available for Iceland. Data for Norway includes only foreign controlled.

Source: Statistics Denmark, Finland, Iceland, Norway and Sweden; national database on non-financial business sector linked with international trade in goods statistics, cf. Annex.

In terms of productivity, the group of domestically controlled firms with foreign affiliates top the list in Denmark (EUR 133,800) and Sweden (EUR 126,300) topped the list followed by the foreign owned enterprises with less than EUR 100,000 per full time employee in both Sweden and Denmark. In Finland the productivity per full time employee was highest in the domestically owned enterprises without foreign affiliates (EUR 140,000).

We can observe a similar development in productivity since 2008 as the foreign owned enterprises in all Nordic countries except Norway experience a growth in productivity $-19 \%$ in Sweden, $12 \%$ in Finland and $1 \%$ in Denmark, cf. figure 70 . However, in Finland and Denmark, the domestically owned enterprises without foreign affiliates showed the largest productivity growth.

In Denmark, the growth in exports per full time employee was mainly caused by a considerable growth of $23 \%$ during the period for foreign owned enterprises, while both in Finland $(-22 \%)$ and Norway $(-3 \%)$ the foreign owned enterprises reported a decrease, cf. figure 70. 


\subsection{Ownership and manufacturing}

As previously mentioned, the majority of the exports of goods from the Nordic countries are carried out by the manufacturing enterprises themselves. In this section, the manufacturing enterprises are broken down by type of ownership to get a more detailed picture of the importance of type of ownership for exports and productivity in the manufacturing sector.

As for the firms in general, we see a very different picture across the Nordic countries as more than half of manufacturing exports in Sweden are by foreign owned enterprises. Foreign controlled enterprises also contribute more to exports than the other two enterprise categories in Norway (48\%), while this group comes second in Denmark $(35 \%)$ and Finland $(29 \%)$, see figure 71 . Denmark is characterised by the high share of exports (49\%) from domestic MNEs (domestically owned enterprises with foreign affiliates), due to the strongholds such as medical products or windmills which are mainly produced and exported by domestically owned enterprises. In Finland, the domestically owned enterprises without foreign affiliates are the largest group accounting for $45 \%$ of total exports of goods.

Figure 71: Manufacturing: Exports of goods by ownership category

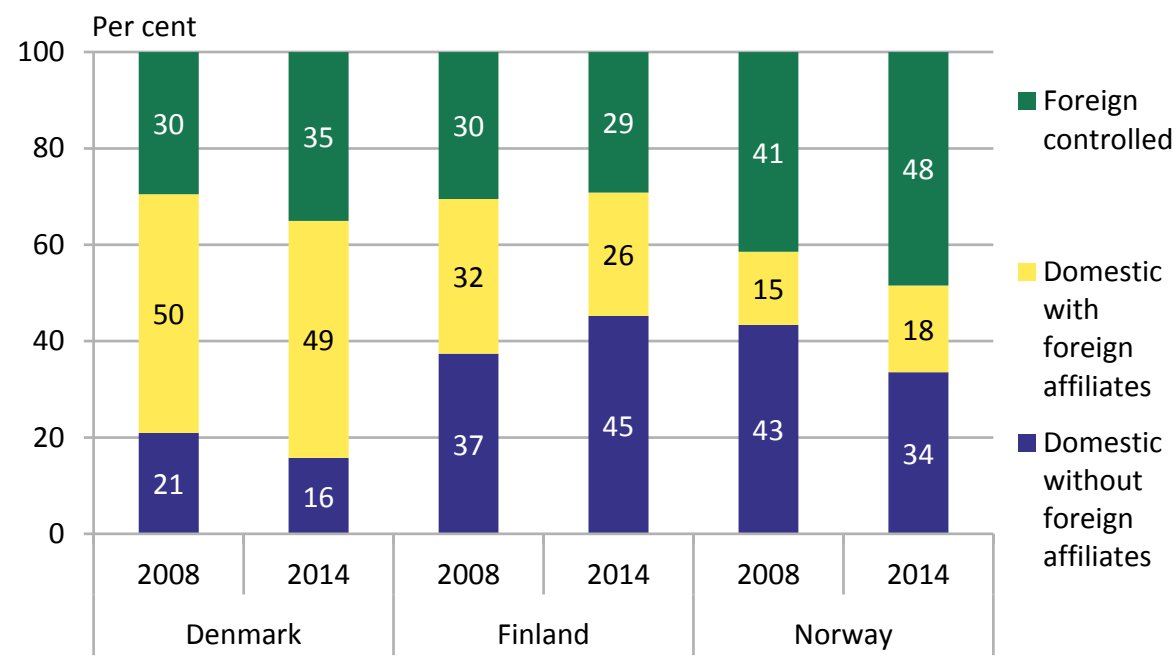

Note: Data for Sweden not available due to confidentiality. No data available for Iceland.

Source: Statistics Denmark, Finland, Iceland, Norway and Sweden; national database on non-financial business sector linked with international trade in goods statistics, cf. Annex. 
Previous results showed that the exporting enterprises since the crisis had become more productive than the ones only serving the domestic markets. These findings are largely supported by the development in productivity broken down by type of ownership, see figure 72 .

\section{Figure 72: Value added per employee (FTE). 2014}

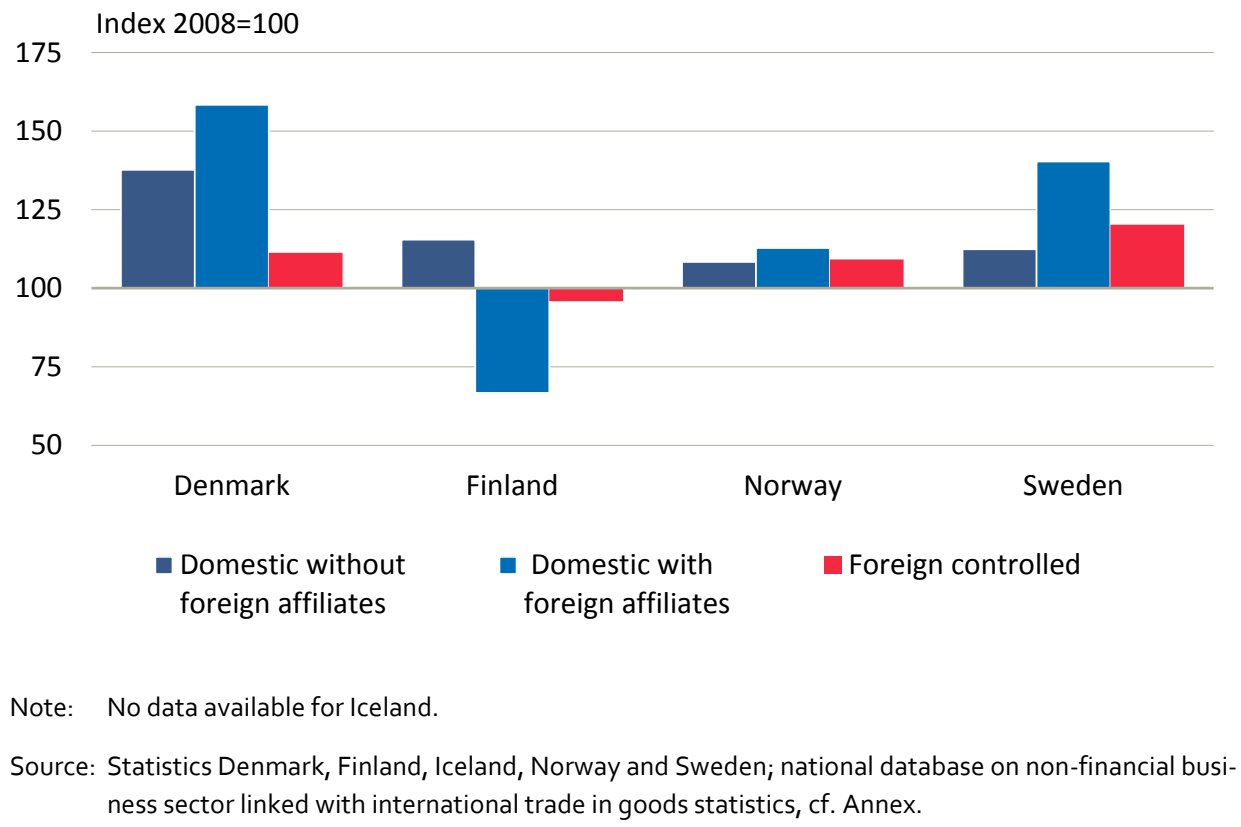

In Denmark, the domestic MNEs which represented the largest share of exports also had the largest increase in gross value added per employee which increased with $58 \%$ in the period 2008 to 2014. In Finland, the largest growth in productivity (15\%) can be found in the domestically owned enterprises without foreign affiliates which also accounted for the largest share of total exports from Finland. But in Sweden and Norway where, the foreign owned enterprises accounted for the largest share of exports also had the largest growth in productivity (16\%).

When looking at the absolute level of gross value added creation per employee, the picture is a bit different as the foreign owned enterprises in both Sweden and Finland show the largest productivity (EUR 114,900 per full time employee in Sweden and EUR 94,400 in Finland) while in Denmark, the domestic MNEs with foreign affiliates showed the largest productivity (EUR 150,600) compared to a value added creation per full time employee in the foreign owned enterprises of EUR 97,500. 
Figure 73: Exports of goods by ownership category and export destination. Manufacturing 2014

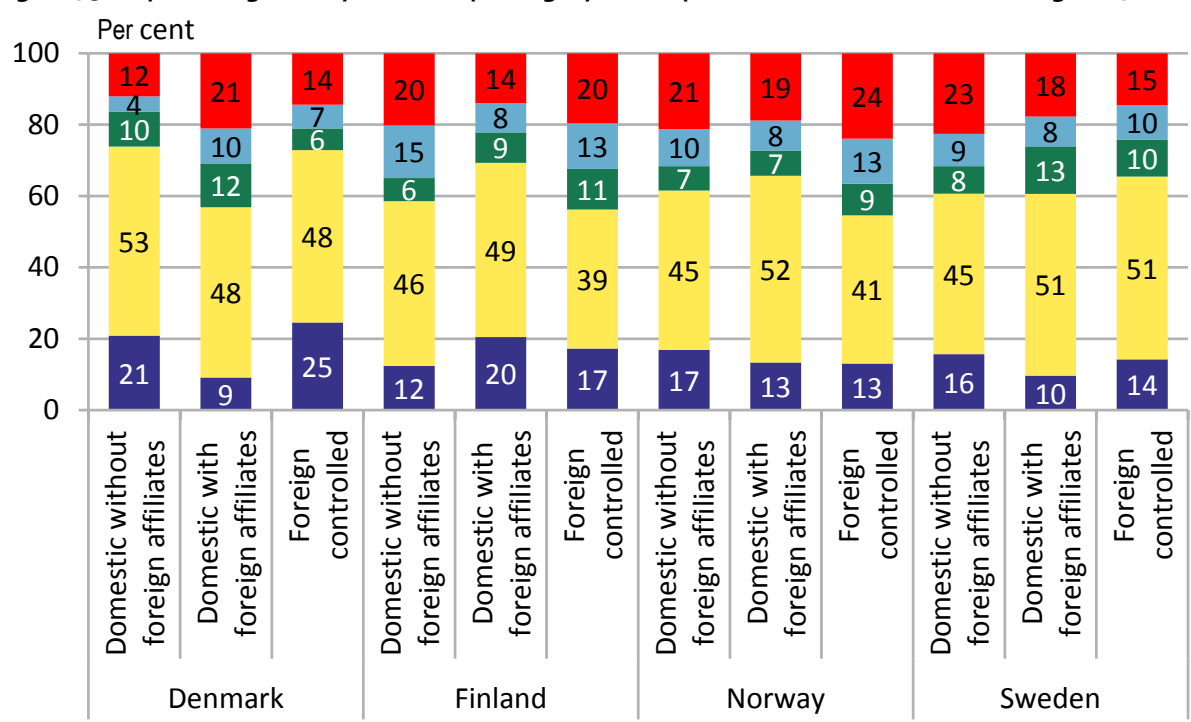

Nordic countries Other EU $\square$ USA and Canada $\square$ BRIC $\square$ Rest of world

Note: No data available for Iceland.

Source: Statistics Denmark, Finland, Iceland, Norway and Sweden; national database on non-financial business sector linked with international trade in goods statistics, cf. Annex.

Perhaps surprisingly, foreign owned enterprises do not show a market composition different from the domestically owned enterprises. The foreign investments are apparently not primarily driven by the motivation of securing a location in an EU country and thus being part of the internal market. The only slight difference is a somewhat larger share of exports from foreign owned enterprises going to BRIC countries, possibly indicating an integration into globally highly dispersed organisation of production by MNEs. 


\section{Nordic Born Globals}

\section{Main findings}

- This chapter presents the first cross-Nordic analysis of born globals, covering a total of 360,783 new enterprises born in the period 2008-2011. 9,113 of these are characterised as born globals, which are defined as new enterprises with exports in their birth year or the subsequent year.

- Born globals make up a higher share of new enterprises in Denmark and Iceland than in Finland, Sweden and Norway. There does not appear to have been a dramatic rise in the number of born globals created in the Nordic region during this period.

- The survival rate of born globals is considerably higher than that of other new enterprises - in all five countries.

- A considerable number of born globals begin to export already in their birth year. The analysis further corroborates findings in other studies that very few of the other new enterprises begin to export goods later on, if they do not begin to do so already from early on.

- The average number of employees per born global is at least twice as high as in the other new enterprises - and employment in born globals grows much more, too.

\subsection{Introduction}

Globalisation has affected the internationalisation of business activities profoundly in recent decades. This is also the case when it comes to new enterprises, an increasing number of which are said to be internationally oriented from early on. International entrepreneurship and the phenomenon of born globals have attracted considerable attention from policy makers and academia alike, ${ }^{28}$ and for good reasons: if the conventional incremental internationalisation process of firms is giving way to early and rapid internationalisation paths of new enterprises, new policies may be needed, and studies documenting the phenomenon will be in demand to inform policy making.

\footnotetext{
${ }^{28}$ Gary Knight (2015), Born Global Firms: Evolution of a Contemporary Phenomenon, in Shaoming Zou , Hui Xu , Linda Hui Shi (ed.) Entrepreneurship in International Marketing (Advances in International Marketing, Volume 25), Emerald Group Publishing Limited, pp.3-19.
} 
This chapter presents the first cross-Nordic analysis of the internationalisation of new enterprises based on extensive statistical databases from each of the Nordic statistical agencies, comparing born globals with other new enterprises. In spite of the fact that there has been a growing body of literature on international entrepreneurship and born globals since the early 1990s, empirical studies based on solid quantitative data material are still very limited in number. ${ }^{29}$ Much of the empirical work is in the form of case studies or is based on surveys with rather small samples (and often also low response rates) and in many cases also with a narrow focus, on a specific manufacturing subsector in a given country, for example.

\subsection{Nordic Born Globals: How many?}

The number of new enterprises covered in this analysis is 360,783 in total for the Nordic countries - except Iceland - from the period 2008-2011. 9,113 of these are characterised as born globals, which are defined as new enterprises with exports in their birth year or the subsequent year.

The creation of new enterprises was generally impacted negatively by the international economic crisis with a decrease in numbers in 2009 in all five Nordic countries. After that, the numbers increased again. The data show that the born globals defined as new enterprises with exports in their birth year or the subsequent year make up a higher share of new enterprises in Denmark and Iceland than in the other countries. The share is in the area of 5 to $6 \%$ of all new enterprises. The share is significantly lower in Norway, Finland and Sweden. This is what one would expect, considering the size of the Danish and Icelandic economies, plus the Danish geographical location and the fact that a higher proportion of Danish enterprises are exporters.

The data available do not provide long time series, and there has been an economic crisis, so one should be careful with interpreting trends out of such results. These reservations notwithstanding, there does not appear to have been a dramatic rise in born

\footnotetext{
29 See e.g. chapter 6 in Statistics Netherlands (2012), Internationalisation Monitor 2012 (The Hague: CBS); Torbjörn Halldin (2012), Born global firms - do they perform differently?, Centre of Excellence for Science and Innovation Studies Working Paper No. 269, Royal Institute of Technology, Sweden; Tage K. Madsen (2013), "Early and rapidly internationalizing ventures: Similarities and differences between classifications based on the original new venture and born global literatures", in Journal of International Entrepreneurship, vol. 11, p. 65-79; Leo Sleuwaegen and Jonas Onkelinx (2014), "International commitment, post-entry growth and survival of new ventures", in Journal of Business Venturing, vol. 29, p. 106-120; Tiia Vissak and Jaan Masso (2015), "Export patterns: Typology development and application to Estonian data" in International Business Review, vol. 24, p. 652-664; M. Baum, C. Schwens and R. Kabst (2015), "A latent class analysis of small firms' internationalization patterns" in Journal of World Business, vol. 50, p. 754-768.
} 
globals created in the Nordic region in this period, neither in absolute numbers or relative to the total number of new enterprises, see figure 74 .

Figure 74: Number of born globals as share of all new enterprises in birth year. 2008-2011

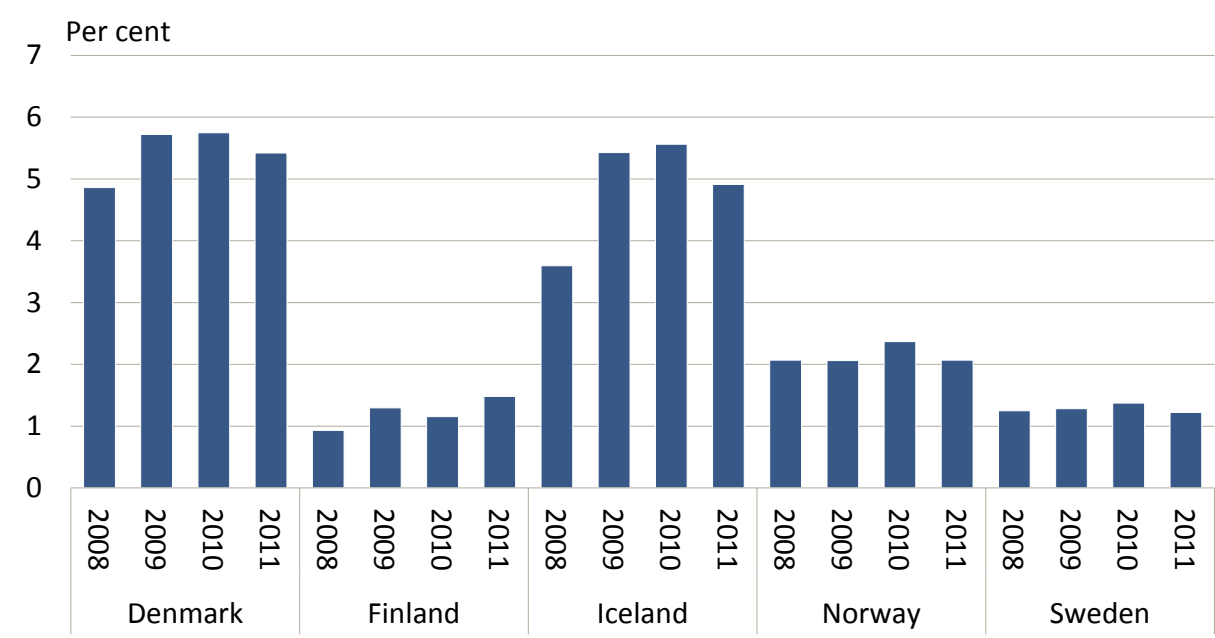

Source: Statistics Denmark, Finland, Iceland, Norway and Sweden; national database on non-financial business sector linked with international trade in goods statistics, cf. Annex.

\subsection{Survival rates}

One of the questions that attract attention, when it comes to born globals and new enterprises per se, is the survival prospects: how many new enterprises manage to survive, in particular the first years of existence? And, for born globals, are their chances of survival better than those of other new enterprises - or are they actually worse?

The few studies that offer insights into this question do not give clear evidence. Statistics Netherlands, operating with data sources and definitions similar to those used here, suggest that born globals do indeed tend to have better chances of survival than other new enterprises..$^{30}$

Looking at the results from the Nordics, the survival rate of born globals is higher than that of other new enterprises - in all five countries. And the differences in survival rates are considerable across the board, as figure 75 illustrates.

$3^{\circ}$ Statistics Netherlands (2012), p. 136. 
Figure 75: Survival rates for born globals and other new enterprises. Three years after birth year

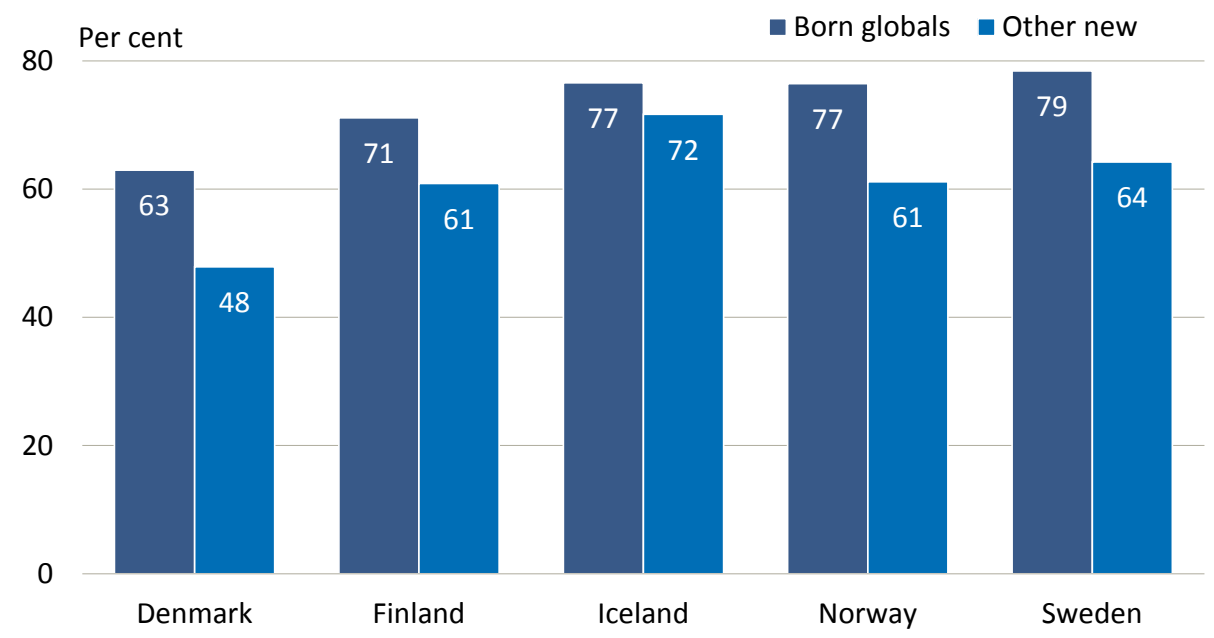

Source: Statistics Denmark, Finland, Iceland, Norway and Sweden; national database on non-financial business sector linked with international trade in goods statistics, cf. Annex.

\subsection{Export intensity}

A considerable number of born globals begin to export already in the first year of their existence. In Denmark just over 60\%, while in Finland and Sweden some 53 and 44\%, respectively, of born globals sell abroad already in their birth year. The figure for Norway is $43 \%$. The remaining born globals, by definition, begin to export in the year after their birth year.

For a considerable share of born globals exports account for less than $5 \%$ of turnover at this early stage of their life (looking at exports in the year of birth or the first year after that for those that do not export in the birth year). The share is considerably higher for Norway and Sweden than the other Nordic countries. These born globals would thus not have been considered exporting enterprises under the definitions used elsewhere in this report, i.e. that exporting enterprises should export goods with a value of at least EUR 5,000 and accounting for at least $5 \%$ of the enterprise's turnover.

On the other hand, a considerable share of the born globals does receive $5 \%$ or more of their turnover from the exports they generate, see figure 76 . In Denmark and Finland 41 and $35 \%$, respectively, export goods amounting to $5-50 \%$ of turnover, while approximately one in every four born globals in Norway and Sweden start out with an export intensity in this interval. 
In Denmark, Finland and Iceland one in every five born globals get more than half of their turnover from exports, even at this early stage. This is a quite high export intensity, even for older and more established exporting enterprises. Again, the corresponding share in Norway and Sweden is much lower.

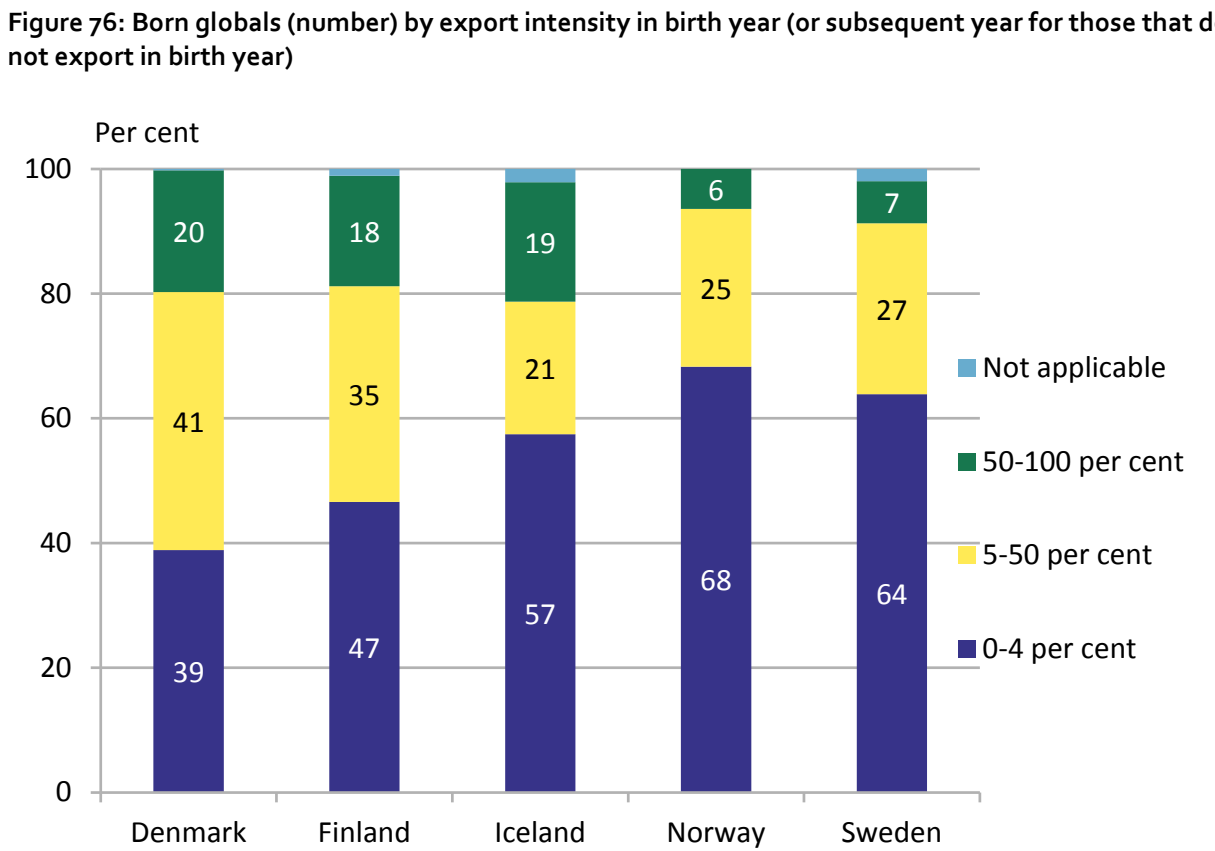

Source: Statistics Denmark, Finland, Iceland, Norway and Sweden; national database on non-financial business sector linked with international trade in goods statistics, cf. Annex.

A considerable share of the born globals that were still active did not export goods three year after their birth. The shares are somewhat higher for Iceland, Sweden and Norway than for Denmark and Finland.

Around $20 \%$ of the born globals in Denmark and Finland, with some higher shares in Iceland, Sweden and Norway, showed exports accounting for less than $5 \%$ of their turnover in year three after their birth. That leaves around $40 \%$ in Denmark and Finland with an export intensity of $5 \%$ or more - and in both countries $16 \%$ with more than half of turnover stemming from exports. The share of born globals with an export intensity of $50 \%$ or more is much lower in Sweden and Norway. 
As far as the other new enterprises are concerned, the data shows that in all five countries there are very few entrepreneurs that export goods three years after birth, if they did not begin to do so already in the early phase..$^{31}$

Figure 77: Born globals and other new enterprises (number) by export intensity in year 3 after birth year

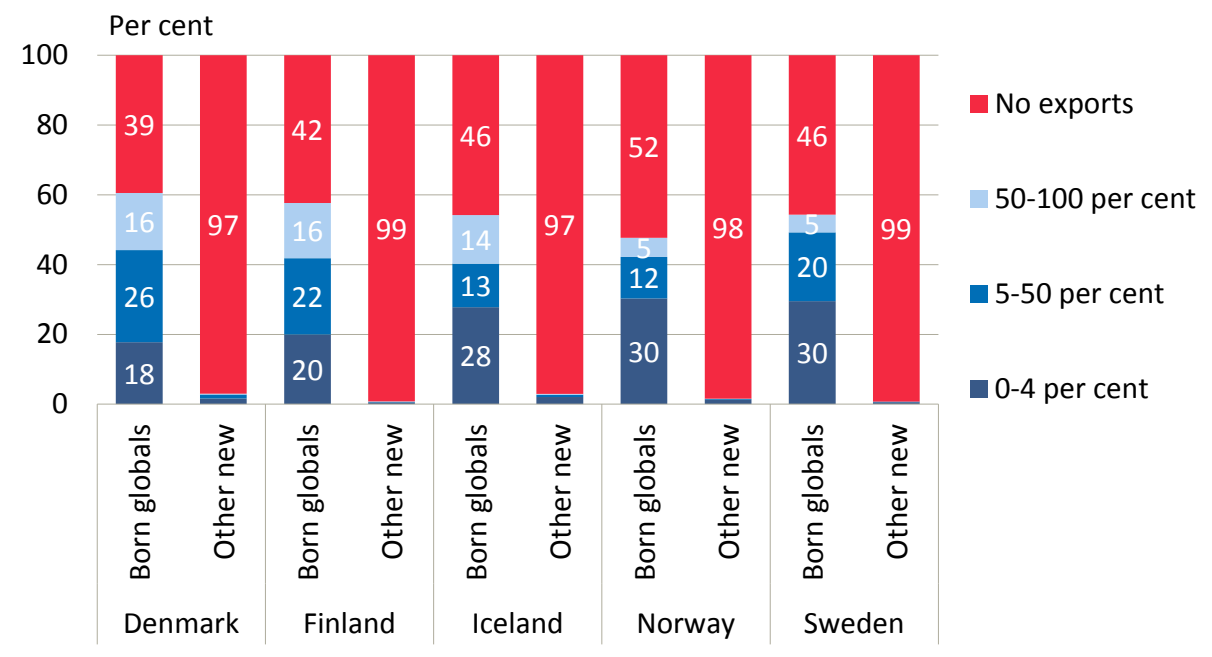

Source: Statistics Denmark, Finland, Iceland, Norway and Sweden; national database on non-financial business sector linked with international trade in goods statistics, cf. Annex.

\subsection{Export markets}

Comparing the geographical export patterns of born globals to exporting enterprises not newly born, the born globals in the Nordics surprisingly seem to export less to the other Nordic countries than do the more established exporters. This is the case, except for the born globals from Sweden whose Nordic region exports account for $29 \%$ of their total exports three years after birth, against $22 \%$ for the other exporting enterprises.

For the born globals in Denmark, exports to other EU countries and the rest of the world categories account for a higher share than is the case for the other exporting enterprises.

The BRIC markets are quite important for the Norwegian born globals, with $29 \%$ of export sales going to these four countries compared to $9 \%$ for the established Norwegian exporters. Born global exports to BRIC markets also account for a relatively high

${ }^{31}$ Statistics Netherlands came to a similar conclusion in their analysis of born globals (2012, p. 133). 
share in Finland, while for the other countries they account for around $5 \%$ for the born globals compared to around $8 \%$ for established exporters.

Figure 78: Exports of goods by export destinations. Born globals in year three after birth year. Compared to not-new exporting enterprises in 2014

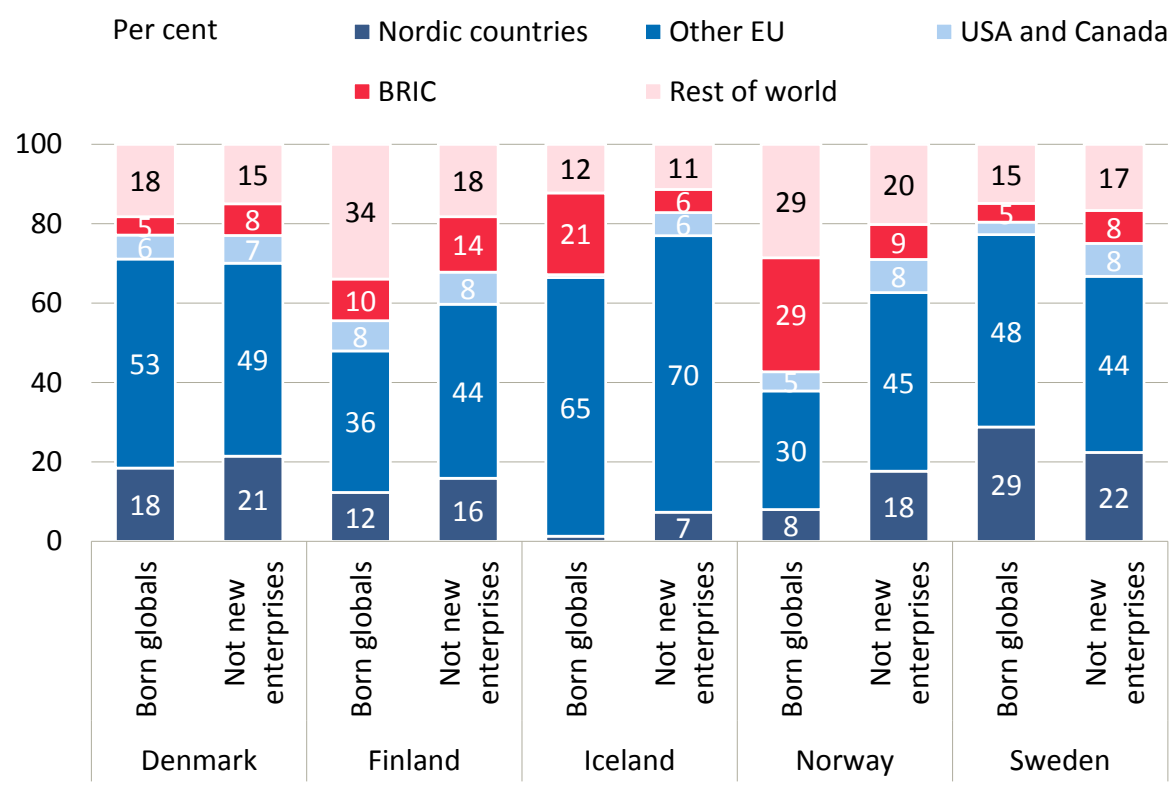

Source: Statistics Denmark, Finland, Iceland, Norway and Sweden; national database on non-financial business sector linked with international trade in goods statistics, cf. Annex.

For both the Finnish and the Norwegian born globals, exports to other EU countries contributes less to their total exports than is the case for their more established exporting countrymen.

For Iceland, it is noteworthy not only that other EU countries are much more important than is the case for the other Nordic countries, but also that the BRIC markets are relatively more important for the Icelandic born globals than the established exporters from Iceland - and that the opposite is the case when it comes to the US and Canadian markets. 


\subsection{Employment}

In addition to export growth and survival, another important issue related to born globals and new enterprises in general is obviously that of employment. Existing studies suggest that born globals generate more jobs than other new enterprises. ${ }^{32}$ The results based on the present cross-Nordic analysis also show that born globals on average generate more employment than the other new enterprises: in all four countries, the born globals that are still active three years after birth had an average full-time employment that was higher than that of the other new enterprises, both in year of birth and three years after.

The average number of full-time employees per born global in year three after birth is twice as high or even higher compared to the other new enterprises.

Moreover, the average number of full-time employees per born global grew considerably more in all four countries than did the same number for the other new enterprises. So, the born globals are certainly also interesting from an employment perspective.

Figure 79: Average employment (number of FTEs) per enterprise in birth year and year three after birth. Born globals and other new enterprises

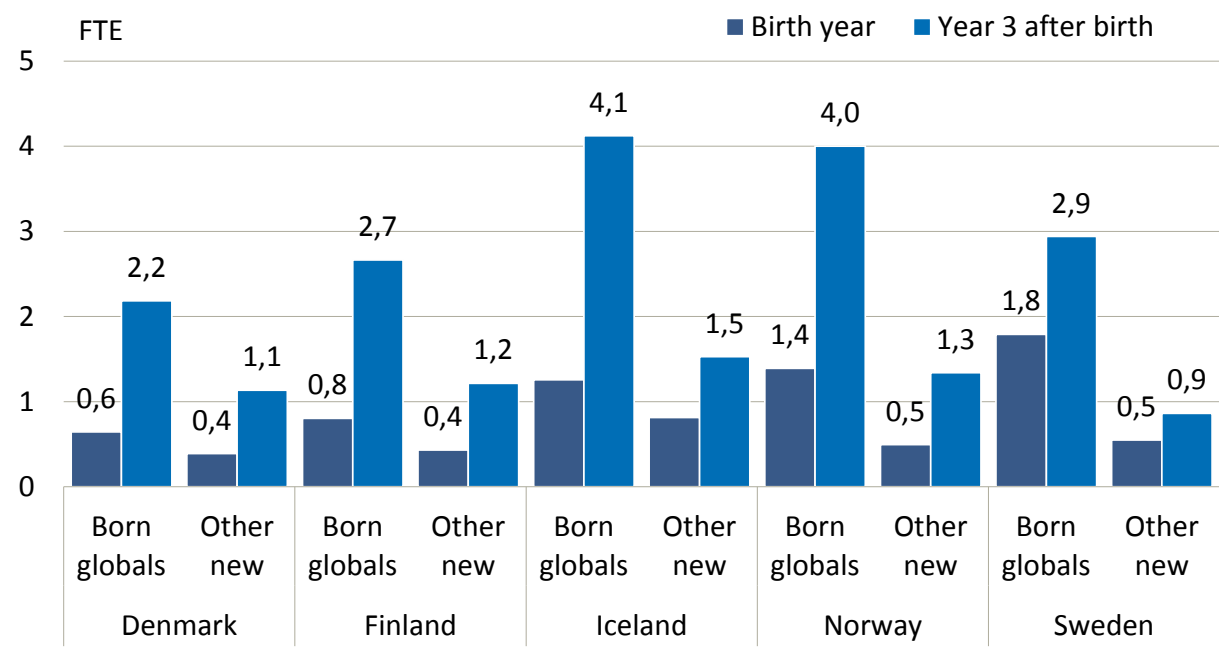

Source: Statistics Denmark, Finland, Iceland, Norway and Sweden; national database on non-financial business sector linked with international trade in goods statistics, cf. Annex.

${ }^{32}$ See e.g. Halldin (2012), p. 18. 


\section{Dansk sammenfatning}

Denne analyse følger op på publikationen Nordic Exports of Goods and Exporting Enterprise fra 2014. ${ }^{33}$ Udover en opdatering af den tidligere analyse bidrager den nærværende rapport med ny viden om forskellige aspekter knyttet til virksomheder i de nordiske lande i relation til globaliseringen og globale værdikæder:

- Analysen dækker denne gang også international handel med tjenester, som er af stigende betydning for de nordiske lande.

- Analysen bidrager ligeledes med profilering af virksomheder, der er engageret $\mathrm{i}$ international handel med tjenester, og er som sådan den første komparative analyse af sin art.

- De vareeksporterende virksomheder i de nordiske lande analyseres yderligere med fokus på virksomhedernes forskellige karakteristika og disses betydning for virksomhedernes performance - virksomhedsstørrelse (med fokus på små og mellemstore virksomheder, SMV'ere), ejerskabsland samt alder (internationalt orienterede nye virksomheder, herunder de såkaldte born globals).

Kapitel 1 giver en oversigt over de nordiske landes økonomier med fokus på udenrigshandel og eksportmæssige styrkepositioner (for varehandlen). De nordiske lande er blandt verdens rigeste, men den økonomiske vækst har haltet som følge af krisen i 2008.

Alle de nordiske lande, med undtagelse af Island, var mindre eksponerede for international handel i 2015 end i 2008 (målt på handel i relation til BNP). Det er en udvikling, de kun har til fælles med to andre EU-lande (Malta og Storbritannien). I 2015 var de nordiske landes samlede eksport af varer og tjenester på 557 mia. EUR, svarende til 8,7 $\%$ af den samlede EU-28 eksport. Vareeksporten udgjorde $67 \%$, mens eksporten af tjenester udgjorde $33 \%$.

Sammenlagt var de nordiske landes eksport af varer i 2015 på 364 mia. EUR. Det var 23 mia. EUR lavere end i 2008, og 38 mia. EUR lavere end i 2012, hvor eksporten i

33 Nordic Exports of Goods and Exporting Enterprise published by Nordic Council of Ministers 2014 as a result of a joint project between Statistics Denmark, Statistics Finland, Statistics Iceland, Statistics Norway and Statistics Sweden. 
den dækkede periode var på sit højeste. EU er uden sammenligning den væsentligste samhandelspartner for alle de nordiske lande. Norge og Island er især afhængige af EU som eksport destination, idet mere end $70 \%$ af de to landes samlede vareeksport går til ikke-nordiske EU-lande.

Den nordiske region betyder som eksport destination for varer mest for Danmark og Sverige, mindst for Island. I 2015 gik $24 \%$ af Sveriges og $21 \%$ af Danmarks samlede vareeksport (målt på værdi) til et andet nordisk land, mens den tilsvarende andel for Islands vedkommende kun var $8 \%$.

Råolie er den mest betydelige varegruppe inden for eksporten med 43 mia. EUR, eller $12 \%$ af den samlede nordiske vareeksport i 2015. Andre nordiske styrkepositioner omfatter fisk mv., papir og pap samt kraftmaskiner og motorer.

Kapitel 2 præsenter den første tvær-nordiske analyse af udenrigshandel med tjenester og virksomhederne, der er engageret heri. Sverige er den største tjenesteeksportør blandt de nordiske lande med en samlet eksport af tjenester på 56,6 mia. EUR i 2014. Danmark eksporterede for en smule mindre (54,9 mia. EUR), og de øvrige nordiske lande betydeligt mindre: Norge eksporterede tjenester for 37,8 mia. EUR, Finland for 21,2 mia. EUR og Island for 3,2 mia. EUR.

I perioden 2010 til 2014 har tjenesteeksporten udviklet sig forskelligt for de nordiske lande. Island har oplevet en vækst i eksporten på $42 \%$, mens den svenske eksport steg med $38 \%$ og den norske med $20 \%$. Den danske eksport steg med $18 \%$. og den finske med $1 \%$. Til sammenligning steg den samlede $\mathrm{EU}_{28} 8$ eksport af tjenester med $29 \%$.

Handlen mellem de nordiske lande er betydelig. Generelt går omkring en femtedel af landenes tjenesteeksport til de øvrige nordiske lande. De nordiske landes tjenesteeksport er koncentreret om nogle få tjenestekategorier. Transporttjenester er den største gruppe og udgør 32,4\% af den samlede nordiske tjenesteeksport i 2014. Den nordiske eksport af transporttjenester svarer til hele $17,9 \%$ af den samlede EU28 eksport af disse tjenester i 2014. Andre styrkepositioner omfatter telekommunikations- samt bygge- og anlægstjenester.

I alle de nordiske lande, med undtagelse af Danmark, står indenlandsk ejede virksomheder uden datterselskaber i udlandet for størstedelen af den internationale tjenestehandel.

Kapitel 3 vedrører eksporterende og ikke-eksporterende virksomheder og fokuserer til dels på industrien. De vare-eksporterende virksomheder bidrager væsentligt til beskæftigelsen og værditilvæksten i de nordiske lande. De eksporterende virksomheder er vigtigst i Danmark, hvor de bidrager med $27 \%$ af den samlede beskæftigelse og $32 \%$ af værditilvæksten i de ikke-finansielle, markedsmæssige erhverv i 2014. 
Eksporterende virksomheder inden for industrien står for en høj andel af den samlede vareeksport $i$ alle de nordiske lande, og de bidrager ligeledes mest til beskæftigelsen inden for industrien, med undtagelse af Norge. Siden 2008 har de eksporterende virksomheder inden for industrien i Danmark, Finland og Sverige imidlertid mistet mere beskæftigelse end de ikke-eksporterende virksomheder. Det modsatte gør sig gældende for Norge. Samlet set har de eksporterende virksomheder i disse fire nordiske lande mistet mere end 200.00o fuldtidsbeskæftigede i perioden 2008-2014-eller hvad der svarer til $20 \%$ af den samlede beskæftigelse i de eksporterende industrivirksomheder i 2008.

De eksporterende virksomheder er generelt mere produktive end de ikke-eksporterende virksomheder inden for industrien. I Danmark, Finland, Norge og Sverige er værditilvæksten pr. fuldtidsbeskæftiget betydeligt højere i de eksporterende virksomheder end i de ikke-eksporterende. I alle fire lande har værditilvæksten pr. fuldtidsbeskæftiget endvidere udviklet sig mere positivt i de eksporterende virksomheder end i de ikke-eksporterende, særligt i Danmark.

Den geografiske fordeling af eksporten er relativt ensartet for de nordiske lande. Omkring $15 \%$ af industrieksporten går til det nordiske område, mens det øvrige EU udgør det største marked med 44-49\% af den samlede industrieksport i de nordiske lande.

Kapitel 4 præsenterer ny viden om små og mellemstore virksomheder (SMV'ere), der konventionelt betragtes som væsentlige i forhold til økonomisk vækst og jobskabelse, ligesom de i forhold til formulering af erhvervspolitik også ses som havende et stort eksportpotentiale. I den nærværende analyse benyttes nye data og en raffinering af den traditionelle statistiske definition af SMV'ere (baseret på beskæftigelse i den enkelte virksomhed), så der tages højde for tilhørsforhold til virksomhedskoncerner og eksterne ejer relationer. Der fokuseres på uafhængige SMV'ere, afhængige SMV'ere og SMV'ere med tilhør til store koncerner, som beskrevet nærmere i kapitel 4.

I alle de nordiske lande består langt størstedelen af virksomhederne af uafhængige SMV'ere, der ligeledes bidrager til mere end halvdelen af den samlede SMV-beskæftigelse. SMV'ere med tilhør til store koncerner, som udgør mindre end $5 \%$ af det samlede antal SMV'ere, bidrager imidlertid med omkring en tredjedel af den samlede SMV-beskæftigelse i Norden. Det samme gør sig gældende for værditilvæksten. Ydermere er denne gruppe særligt betydende for eksporten, hvor denne type virksomheder står for mere end to tredjedele af den samlede SMV-eksport af varer i Finland og for halvdelen i Danmark.

Denne nye måde at opdele SMV'ere på anses som særdeles vigtig i relation til politikformulering, idet en så betydelig andel af den samlede SMV-eksport således genereres af SMV'ere med tilknytning til store koncerner - og disse kunne med rette betragtes 
som store virksomheder i denne sammenhæng, givet deres tilknytning til store koncerner. Udtrykt på en anden måde, så er betydningen af de "reelle" SMV'ere for de nordiske landes eksport mere begrænset, idet de fx blot bidrager med $26 \%$ af den samlede vareeksport i Danmark, 20 \% i Norge, og 12 \% i både Finland og Sverige.

Kapitel 5 belyser virksomhedskarakteristika knyttet til ejerland. Der skelnes grundlæggende mellem indenlandsk og udenlandsk ejerskab, og for de indenlandsk ejede mellem virksomheder hhv. med og uden datterselskaber i udlandet (dvs. om der er tale om indenlandske multinationale virksomheder eller ej).

I kapitlets afsnit, hvor der fokuseres på industrien, viser resultaterne et varieret billede for de nordiske lande. I Sverige stammer mere end halvdelen af vareeksporten fra de udenlandsk ejede virksomheder, mens andelene i Danmark og Finland er betydeligt lavere. Den danske eksport er karakteriseret ved, at en høj andel heraf stammer fra indenlandsk ejede multinationale virksomheder, bl.a. på grund af det overvejende indenlandske ejerskab inden for centrale styrkepositioner såsom medicinalindustrien, mens den svenske styrkeposition inden for køretøjer er forbundet med en høj grad af udenlandsk ejerskab. I Finland står de indenlandsk ejede virksomheder uden udenlandske datterselskaber for næsten halvdelen af den samlede industrieksport.

Den geografiske fordeling af de udenlandsk ejede virksomheders eksport er, måske lidt overraskende, ikke markant forskellig fra fordelingen af de indenlandsk ejede virksomheders eksport. Der er dog en mindre forskel, da en lidt højere andel af de udenlandsk ejede virksomheders eksport går til BRIK landene, end det er tilfældet for de indenlandsk ejede virksomheder.

Kapitel 6 præsenterer den første tvær-nordiske analyse af born globals, baseret på et datagrundlag med 360.800 nye virksomheder fra perioden 2008-2011. Mere end 9.100 af disse er kategoriseret som born globals ud fra en definition om, at de havde eksport enten i fødselsåret eller i det derpå følgende år.

Born globals udgør en højere andel af det samlede antal nye virksomheder i Danmark og Island, mens andelen er betydeligt lavere i Finland, Sverige og Norge. Der synes ikke at have været en dramatisk stigning i antallet af born globals, ej heller i absolutte termer, i de nordiske lande i perioden.

Analysen viser, at overlevelsesraten for born globals er markant højere end for de øvrige nye virksomheder, der blev født i samme periode - og det gælder i alle fem nordiske lande.

Herudover viser analysen, at et betragteligt antal born globals faktisk begynder at eksportere allerede i fødselsåret, og den underbygger konklusionen i andre undersøgelser, at meget få nye virksomheder begynder at eksportere, hvis de ikke gør det fra starten af. 
Endelig viser analysen, at den gennemsnitlige beskæftigelse i born globals virksomhederne er mindst dobbelt så høj som i de øvrige nye virksomheder - og at beskæftigelsen i born globals virksomheder herudover vokser mere i de første år, end det er tilfældet i de øvrige nye virksomheder. 



\section{Annex: \\ Data sources and methodology}

The present analysis has been carried out in the period from May to October 2016 by Statistics Denmark, in close collaboration with the statistical institutes in Finland, Iceland, Norway and Sweden. This annex contains a description of the data sources and methodologies used.

Throughout the publication the Eurostat/ECU exchange rates have been used for converting national currencies to EUR (table ert_bil_eur_a).

Table 2: Eurostat exchange rates

\begin{tabular}{lrrrrrrr} 
& 2008 & 2009 & 2010 & 2011 & 2012 & 2013 & $\mathbf{2 0 1 4}$ \\
\hline Danish krone & 7,4560 & 7,4462 & 7,4473 & 7,4506 & 7,4437 & 7,4579 & 7,4548 \\
Swedish krona & 9,6152 & 10,6191 & 9,5373 & 9,0298 & 8,7041 & 8,6515 & 9,0985 \\
Icelandic krona & 143,83 & 172,67 & 161,89 & 161,42 & 160,73 & 162,38 & 154,86 \\
Norwegian krone & 8,2237 & 8,7278 & 8,0043 & 7,7934 & 7,4751 & 7,8067 & 8,3544 \\
\hline
\end{tabular}

\section{National databases of business and trade data}

The analysis has been carried out using national databases that were constructed by each statistical institute in accordance with guidelines developed by Statistics Denmark under a previous project for the Nordic Council of Ministers (Nordic businesses in a globalised world, 2013-2014). The databases have been updated with new reference periods and extended to cover more data sources than previously, cf. below. The outputs have been produced at national level using harmonised SAS syntax developed by Statistics Denmark.

The databases cover all active enterprises in the non-financial business economy (NACE Rev. 2 sections B to N, excl. K) for the period 2008 to 2014, the latter being the most recent year available across the Nordic countries when it comes to annual business statistics.

In each database, annual business statistics data is linked through the national business registers at enterprise level with information on the international trade in goods 
and international trade in services as well as data on new enterprises from the annual business demography statistics.

The following contains a description of sources and methodological issues, followed by a section on each of the Nordic countries where additional information is provided.

\section{International trade in goods data}

The micro-level data on international trade in goods is taken from the International Trade in Goods Statistics, and this is linked to other statistical sources through the national business registers.

The results presented in this analysis may in some regards differ from the results that are known from the international trade in goods statistics. The main reasons for this are:

- Matching registers: Not all records on international trade in goods can be matched properly at micro-level to a record on an enterprise in business statistics. Thus, some trade in goods is excluded, but it is generally a minor problem.

- Definitions: Some differences also arise because the analysis is focused on enterprises included in the national databases, i.e. in the non-financial business economy (NACE Rev. 2 sections B to N, excl. K). This means that exports by enterprises classified under e.g. agriculture are not included.

Part of the analysis (chapter 1 in particular) is based on international trade in goods data from Eurostat's database, as extracted in July 2016. These data are not delimited by enterprise activity, trading status or size class, as is the case when it comes to the analyses based on national databases of linked micro data.

Minor discrepancies may exist between Eurostat figures and national figures due to the use of a different concept for the data provided to Eurostat (which has to be harmonized according to the Community concept). These reasons can refer to:

- Treatment of goods in "quasi" transit: some Member States, including the Nordic countries, do not record in their national figures certain goods, which they consider to be "in transit". Such flows are included in Eurostat's statistics.

- Different trade system for compilation of statistics: applying the so-called general trade system at national level rather than the so-called special trade system used for Eurostat data. All Nordic countries apply the general trade system. The general 
trade system includes all goods entering or leaving a country with the exception of transit trade. The special trade system, on the other hand, is a narrower concept. Goods from a foreign country which are received into customs warehouses are not recorded in the special trade aggregates unless they subsequently go into free circulation in the country of receipt (or are placed under the customs procedures for inward processing or processing under customs control). Similarly, outgoing goods from customs warehouses are not recorded as exports.

\section{International trade in services data}

\section{Conventional trade data}

Conventional data on international trade in services (ITS) is available at Eurostat's website - both the statistics on ITS and the statistics on balance of payments (BOP). However, not all countries provide a full breakdown on services items and countries, either due to confidentiality or due to other methodological approaches. One of the methodological challenges is the transition to the new manuals on ITS and BOP. EU has required that services figures are delivered according to the Ebops2010 manual for the years 2010 to 2014. In most countries data before 2013 was collected according to the older manuals, and therefore a back casting exercise has been done to create consistent data series. The analysis in this report is narrowed down to the period 2010 to 2014 in order to use data compiled according to the Ebops2010 manual. In the table below the sources and limitations of the data for the five Nordic countries are shown. 
Table 3: Overview of the sources and limitations for the conventional data

\begin{tabular}{|c|c|c|c|c|c|}
\hline & Denmark & Finland & Iceland & Norway & Sweden \\
\hline Source & $\begin{array}{l}\text { ITSS figures from } \\
\text { Eurostat }\end{array}$ & $\begin{array}{l}\text { BOP figures from } \\
\text { Statistics Finland, } \\
\text { ITSS figures from } \\
\text { Eurostat }\end{array}$ & $\begin{array}{l}\text { ITS figures from } \\
\text { Statistics Iceland, } \\
\text { ITSS figures from } \\
\text { Eurostat, } \\
\text { BOP figures from } \\
\text { Statistics Iceland }\end{array}$ & $\begin{array}{l}\text { BOP figures from } \\
\text { Statistics Norway }\end{array}$ & $\begin{array}{l}\text { ITSS figures from } \\
\text { Eurostat }\end{array}$ \\
\hline Geography & & $\begin{array}{l}\text { Distribution on } \\
\text { trade with EU28 } \\
\text { and Nordic coun- } \\
\text { tries not available } \\
\text { for the years } 2010 \\
\text { to } 2012 \text {. }\end{array}$ & $\begin{array}{l}\text { Geographical dis- } \\
\text { tribution not avail- } \\
\text { able for } 2014\end{array}$ & $\begin{array}{l}\text { Trade with Nordic } \\
\text { countries only in- } \\
\text { clude Denmark } \\
\text { and Sweden. }\end{array}$ & \\
\hline $\begin{array}{l}\text { Service } \\
\text { item }\end{array}$ & & $\begin{array}{l}\text { Data on the cross } \\
\text { between service } \\
\text { items and Nordic } \\
\text { countries is not } \\
\text { available. }\end{array}$ & $\begin{array}{l}\text { Data distributes } \\
\text { on Ebops } 2010 \text { cat- } \\
\text { egories available } \\
\text { from } 2013 \text {. Data } \\
\text { on the cross be- } \\
\text { tween service } \\
\text { items and Nordic } \\
\text { countries is only } \\
\text { available for the } \\
\text { largest service } \\
\text { items for } 2014 \text {. }\end{array}$ & $\begin{array}{l}\text { Ebops } 2010 \text { cate- } \\
\text { gories estimated } \\
\text { from the catego- } \\
\text { ries used in the } \\
\text { Norwegian BOP } \\
\text { statistics. Data on } \\
\text { the cross between } \\
\text { service items and } \\
\text { Nordic countries is } \\
\text { not available. }\end{array}$ & \\
\hline $\begin{array}{l}\text { Extraction } \\
\text { date }\end{array}$ & $17-05-2016$ & $\begin{array}{l}\text { Eurostat: } 17-05^{-} \\
2016 \\
\text { Statistics Finland: } \\
\text { 31-08-2016 }\end{array}$ & $\begin{array}{l}\text { Eurostat: 17-05- } \\
2016 \\
\text { Statistics Iceland: } \\
11-07-2016\end{array}$ & $11-07-2016$ & $17-05-2016$ \\
\hline
\end{tabular}

\section{Denmark}

For Denmark all data is available in the Eurostat database for the years 2010 to 2014.

\section{Sweden}

For Sweden all data is available in the Eurostat database for the years 2010 to 2014 .

\section{Finland}

For Finland all information on service items was suppressed in the Eurostat database and data is only available back to 2013. Therefore, BOP figures from Statistics Finland were used as the main source, even though it is lacking adequate information on geography. Geographical partner Europe is therefore used instead of partner EU28, and the cross between partner Nordic countries and services items is not available in the data. 
Iceland

For Iceland all information on geography and service items are available for the year 2013 in the Eurostat database. Total service trade is available for the year 2010 to 2014 in the BOP figures from statistics Iceland, but these figures are not geographically distributed. The geographical distribution for 2010 to 2012 is estimated using ITS data from Statistics Iceland. This is not applicable for the year 2014, but it is possible to distribute the majority of the service exports to the Nordic countries (approx. 90\%) for the year 2014. The valuation in the national BOP figures is in mill. Icelandic crown (ISK) and to calculate the relevant value in EURO, the average yearly exchange rate from Sedlabanki Iceland (the central bank) was used.

Norway

For Norway no information on ITS or BOP is available in Eurostat. Data in this analysis is taken from the national BOP figures from statistics Norway. These figures are partly geographically distributed for the years 2011 to 2014, but Nordic countries only include Denmark and Sweden. The service item is estimated by the name indicated in the Norwegian BOP figures. However only 5 out of 12 Ebops categories was identified, and the remaining trade was allocated to ebops2010 item "not allocated". The valuation in the national BOP figures is in mill. Norwegian crown (NOK) and to calculate the relevant value in EURO, the average yearly exchange rate from Norges Bank (the central bank) was used. Data on the cross between geography and service items are not available.

\section{Micro-level data on international trade in services}

The micro-level data on international trade in services is taken from the survey on international trade in goods statistics (ITS survey), and this is linked to other statistical sources through the national business registers.

The results from the analysis on micro-level data presented in this analysis, is only covering the enterprises that are liable to report to the ITS survey, and is thus not comparable with the conventional ITS figures. The main reasons for this are:

- Matching registers: Not all records on international trade in services can be matched properly at micro-level to a record on an enterprise in business statistics. Thus, some trade in services is excluded in some parts of the analysis, but it is generally a minor problem.

- Grossed up trade: The ITS survey is not a total survey and therefore most of the smaller enterprises are estimated using survey techniques. Grossing up procedure rarely allocate the estimated trade on enterprises which makes it challenging to 
match grossed up trade with the business register. In this analysis, the grossed up trade is excluded.

- Alternative sources: The conventional ITS figures is primarily based on the ITS survey for the enterprises in the economy. However, certain services are not necessarily performed by enterprises, and is thus not collected in the ITS survey. These types of services are:

- Travel services: The consumption of tourists abroad (Danish import) or in Denmark (Danish export).

- Government services: Trade performed by the government with regard to military, embassies and other international operations.

- Private persons purchase of electronic delivered services: Private persons purchase of i.e. computer games from foreign enterprises download directly to the computer.

- Illegal services.

Some countries have outsourced the data collection of e.g. financial services to other institutions, such as the central bank, and will not necessarily have data on the enterprise level for these sources.

Since the alternative sources are not collected on the enterprise level, data cannot be linked with the business register, and therefore data is excluded in this analysis.

Derived values

Some of the information collected in the ITS survey is not the actual service needed, and therefore a calculation has to be done to the data, which sometimes require additional information from other sources. Other services are derived from other sources than the ITS survey. The largest derived services are:

- The freight adjustment on Foreign trade in goods.

- The insurance service related to premiums and claims.

- The indirectly measured financial service on rents (FISIM).

Even though some of the derived values are actually collected in the ITS survey, the calculations are often performed in the dissemination process, and are thus not available at the enterprise level. Derived services are excluded in this analysis. 
The method used to compile ITS is not harmonized across the Nordic countries, so in order to ensure consistency between the five countries, it was agreed to further exclude the following ebops2010 services items from the directly reported data to the ITS survey, in order to have a common denominator:

- 4. Travel.

- 6. Insurance and pension services.

- 7. Financial services.

- 12. Government goods and services n.i.e.

Since the data used in the analysis only is a subset of the figures published in the conventional ITS figures, it has been agreed to merely have data as a share of total, instead of a meaningless value. This approach has the advantage of removing the need for confidentiality, since it will not be possible to derive information at the enterprise level, when the totals are an unknown (and uninteresting) value.

\section{Data on new enterprises and born globals}

The present analysis is based on the extended national database that each of the Nordic statistical agencies have constructed. It covers information on four years' populations of new enterprises (2008 to 2011) from the national business demography statistics on new enterprises.

Using the business demography data, the present analysis offers the advantage, unlike several other studies, of covering only those new enterprises that are truly new as enterprises that come into existence due to mergers, spin-offs, etc. are not considered new. ${ }^{34}$ It should be noted, that new enterprises that are controlled from abroad have been excluded from the population, as they are not truly new and so often atypical and would have distorted the results of the analysis.

A distinction is made between born globals and other new enterprises, as illustrated below.

34 Eurostat and OECD (2007), Eurostat - OECD Manual on Business Demography Statistics (Luxembourg: Office for Official Publications of the European Communities). 
Figure 80: New enterprises, distinction between born globals and other new enterprises

\section{New enterprises}

(excl. foreign controlled)

\section{Born globals}

Export of goods in birth year and/or year after
Other new enterprises

No export of goods birth year and year after

In line with Statistics Netherlands, this is a less restrictive definition of born globals, compared to e.g. a requirement that exports should account for at least $25 \%$ of turnover within the first three years of existence, in order for a new firm to be considered born global. Initial tests on Danish data suggested that such a definition would be too restrictive. Furthermore, no additional requirements - e.g. concerning exports to $x$ number of destinations and/or to other world regions - have been applied. Instead, the analysis provides results on export intensity, number of export destinations etc. for the two groups.

The information on new enterprises from the business demography statistics are linked at enterprise level in the national database of each country with accounts and international trade in goods statistics. Each year's population of new enterprises is followed for a period of three years after the birth year ( $t \_0, t \_1$ to $t \_3$ ), as illustrated below.

Table 4: New enterprises

\begin{tabular}{|c|c|c|c|c|c|c|c|}
\hline \multirow[t]{2}{*}{ Birth year } & \multicolumn{7}{|c|}{ Reference periods } \\
\hline & 2008 & 2009 & 2010 & 2011 & 2012 & 2013 & 2014 \\
\hline 2008 & t_o & $t_{-} 1$ & $t \_2$ & $\mathrm{t} \_3$ & & & \\
\hline 2009 & & t_o & $t \_1$ & t_2 & t_3 & & \\
\hline 2010 & & & $\mathrm{t} \_\mathrm{o}$ & $\mathrm{t} \_1$ & $\mathrm{t} \_2$ & t_3 & \\
\hline 2011 & & & & t_o & t_1 & $t_{-} 2$ & t_3 \\
\hline
\end{tabular}




\section{Country details: Denmark}

The Danish population covers, in $2014,212,282$ enterprises with a total of nearly 1.2 million employees (in full-time equivalents).

Enterprises categorised as exporters account for $98.2 \%$ of the total value of goods exports.

Table 5: Danish database population 2014

\begin{tabular}{lrrrr} 
& Total & Manufacturing & Wholesale & Other sectors \\
Number of enterprises & 212,282 & 15,002 & 22,927 & 174,353 \\
Exporters & 12,080 & 3,822 & 5,151 & 3,107 \\
Non-exporters & 200,202 & 11,180 & 17,776 & 171,246 \\
Employment & $1,167,472$ & 260,552 & 171,155 & 735,765 \\
Exporters & 309,427 & 202,402 & 64,898 & 42,126 \\
Non-exporters & 858,045 & 58,150 & 106,257 & 693,638 \\
Exports of goods (row \%) & 100.0 & 62.6 & 27.3 & 10.0 \\
Exporters & 100.0 & 63.5 & 26.9 & 9.6 \\
Non-exporters & 100.0 & 14.0 & 52.0 & 34.0 \\
Exports of goods (column \%) & 100.0 & 100.0 & 100.0 & 100.0 \\
Exporters & 98.2 & 99.6 & 96.6 & 94.0 \\
Non-exporters & 1.8 & 0.4 & 3.4 & 6.0 \\
\hline
\end{tabular}

Table 6: Danish database population 2014. By size class

\begin{tabular}{|c|c|c|c|c|}
\hline & $\begin{array}{r}\text { Number of enter- } \\
\text { prises }\end{array}$ & Employment & $\begin{array}{l}\text { Number of enter- } \\
\text { prises (\%) }\end{array}$ & $\begin{array}{r}\text { Employment } \\
(\%)\end{array}$ \\
\hline All enterprises & 212,282 & $1,167,472$ & 100.0 & 100.0 \\
\hline SMEs & 211,833 & 763,746 & 99.8 & 65.4 \\
\hline Large enterprises & 449 & 403,726 & 0.2 & 34.6 \\
\hline
\end{tabular}


Table 7: Danish database population 2014. By ownership

\begin{tabular}{lrrrr} 
& $\begin{array}{r}\text { Number of enter- } \\
\text { prises }\end{array}$ & Employment & $\begin{array}{r}\text { Number of enter- } \\
\text { prises (\%) }\end{array}$ & $\begin{array}{r}\text { Employment } \\
(\%)\end{array}$ \\
\hline $\begin{array}{l}\text { All enterprises } \\
212,282\end{array}$ & $1,167,472$ & 100.0 & 100.0 \\
$\begin{array}{l}\text { Domestically controlled } \\
\text { without foreign affiliates }\end{array}$ & 206,795 & 705,323 & 97.4 & 18.6 \\
$\begin{array}{l}\text { Domestically controlled } \\
\text { with foreign affiliates }\end{array}$ & 1,839 & 217,219 & 0.9 & \\
\begin{tabular}{l} 
Foreign controlled \\
\hline
\end{tabular} & 3,648 & 244,929 & 1.7 & 21.0 \\
\hline
\end{tabular}

Table 8: Danish database population 2014. By ownership

\begin{tabular}{l|rrrr} 
& $\begin{array}{r}\text { Number of enter- } \\
\text { prises }\end{array}$ & Employment & $\begin{array}{r}\text { Number of enter- } \\
\text { prises (\%) }\end{array}$ & $\begin{array}{r}\text { Employment } \\
(\%)\end{array}$ \\
\hline $\begin{array}{l}\text { All enterprises } \\
212,282\end{array}$ & $1,167,472$ & 100.0 & 100.0 \\
$\begin{array}{l}\text { Domestically controlled } \\
\text { without foreign affiliates }\end{array}$ & 206,795 & 705,323 & 97.4 & 18.6 \\
$\begin{array}{l}\text { Domestically controlled } \\
\text { with foreign affiliates }\end{array}$ & 1,839 & 217,219 & 0.9 & \\
Foreign controlled & 3,648 & 244,929 & 1.7 & 21.0 \\
\hline
\end{tabular}

Table 9: Danish database population 2014. By ownership

\begin{tabular}{|c|c|c|c|c|}
\hline & $\begin{array}{r}\text { Number of enter- } \\
\text { prises }\end{array}$ & Employment & $\begin{array}{r}\text { Number of enter- } \\
\text { prises (\%) }\end{array}$ & $\begin{array}{r}\text { Employment } \\
(\%)\end{array}$ \\
\hline All enterprises & 212,282 & $1,167,472$ & 100.0 & 100.0 \\
\hline $\begin{array}{l}\text { Domestically controlled } \\
\text { without foreign affiliates }\end{array}$ & 206,795 & 705,323 & 97.4 & 60.4 \\
\hline $\begin{array}{l}\text { Domestically controlled } \\
\text { with foreign affiliates }\end{array}$ & 1,839 & 217,219 & 0.9 & 18.6 \\
\hline Foreign controlled & 3,648 & 244,929 & 1.7 & 21.0 \\
\hline
\end{tabular}


Table 10: New enterprises in Danish database population 2008-2011

\begin{tabular}{lrrrrr} 
& All four years & $\mathbf{2 0 0 8}$ & $\mathbf{2 0 0 9}$ & $\mathbf{2 0 1 0}$ & $\mathbf{2 0 1 1}$ \\
\hline All new enterprises & 92,906 & 25,935 & 19,697 & 22,285 & 24,989 \\
Born globals & 5,024 & 1,261 & 1,127 & 1,281 & 1,355 \\
Other new enterprises & 87,882 & 24,674 & 18,570 & 21,004 & 23,634 \\
\hline
\end{tabular}

\section{Country details: Finland}

The Finnish population covers, in 2014, 363,544 enterprises with a total of 1.3 million employees (in full-time equivalents).

The enterprises categorised as exporters account for $98.4 \%$ of the total value of goods exports.

Table 11: Finnish database population 2014

\begin{tabular}{|c|c|c|c|c|}
\hline & Total & Manufacturing & Wholesale & Other sectors \\
\hline Number of enterprises & 363,544 & 21,042 & 23,979 & 318,523 \\
\hline Exporters & 3,608 & 1,776 & 962 & 870 \\
\hline Non-exporters & 359,936 & 19,266 & 23,017 & 317,653 \\
\hline Employment & $1,296,673$ & 296,646 & 105,670 & 894,357 \\
\hline Exporters & 219,539 & 185,723 & 14,383 & 19,434 \\
\hline Non-exporters & $1,077,134$ & 110,923 & 91,288 & 874,923 \\
\hline Exports of goods (row \%) & 100.0 & 90.9 & $5 \cdot 7$ & $3 \cdot 4$ \\
\hline Exporters & 100.0 & 91.9 & 5.0 & 3.1 \\
\hline Non-exporters & 100.0 & 27.7 & 48.5 & 23.8 \\
\hline Exports of goods (column \%) & 100.0 & 100.0 & 100.0 & 100.0 \\
\hline Exporters & 98.4 & 99.5 & 86.3 & 89.0 \\
\hline Non-exporters & 1.6 & 0.5 & 13.7 & 11.0 \\
\hline
\end{tabular}

Table 12: Finnish database population 2014. By size class

\begin{tabular}{lrrrr} 
& $\begin{array}{r}\text { Number of enter- } \\
\text { prises }\end{array}$ & Employment & $\begin{array}{r}\text { Number of enter- } \\
\text { prises (\%) }\end{array}$ & $\begin{array}{r}\text { Employment } \\
(\%)\end{array}$ \\
All enterprises & 363,544 & $1,296,673$ & & 100.0 \\
SMEs & 362,929 & 814,697 & 99.8 & 100.0 \\
Large enterprises & 581 & 481,976 & 0.2 & 62.8 \\
\hline
\end{tabular}


Table 13: Finnish database population 2014. By ownership

\begin{tabular}{|c|c|c|c|c|}
\hline & $\begin{array}{r}\text { Number of enter- } \\
\text { prises }\end{array}$ & Employment & $\begin{array}{r}\text { Number of enter- } \\
\text { prises (\%) }\end{array}$ & $\begin{array}{r}\text { Employment } \\
(\%)\end{array}$ \\
\hline All enterprises & 363,544 & $1,296,673$ & 100.0 & 100.0 \\
\hline $\begin{array}{l}\text { Domestically controlled } \\
\text { without foreign affiliates }\end{array}$ & 359,827 & 978,027 & 99.0 & 75.4 \\
\hline $\begin{array}{l}\text { Domestically controlled } \\
\text { with foreign affiliates }\end{array}$ & 533 & 82,533 & 0.1 & 6.4 \\
\hline Foreign controlled & 3,184 & 236,114 & 0.9 & 18.2 \\
\hline
\end{tabular}

Table 14: New enterprises in Finish database population 2008-2011

\begin{tabular}{lrrrrr} 
& All four years & 2008 & 2009 & 2010 & 2011 \\
All new enterprises & 43,098 & 12,792 & 10,108 & 10,067 & 10,131 \\
Born globals & 516 & 119 & 131 & 116 & 150 \\
Other new enterprises & 42,582 & 12,673 & 9,977 & 9,951 & 9,981 \\
\hline
\end{tabular}

\section{Country details: Iceland}

The Icelandic population covers 24,775 enterprises, in 2014 , with a total of 98,073 employees (not in full-time equivalents).

The enterprises categorised as exporters account for $98.3 \%$ of the total value of goods exports. 
Table 15: Icelandic database population 2014

\begin{tabular}{lrrrr} 
& Total & Manufacturing & Wholesale & Other sectors \\
Number of enterprises & & & \\
Exporters & 24,775 & 2,005 & 2,309 & 20,461 \\
Non-exporters & 390 & 170 & 130 & 90 \\
Employment & 24,385 & 1,835 & 2,179 & 20,371 \\
Exporters & 98,073 & 21,859 & 10,923 & 65,291 \\
Non-exporters & 12,887 & 9,466 & 1,967 & 1,454 \\
Exports of goods (row \%) & 85,186 & 12,393 & 8,956 & 63,837 \\
Exporters & 100.0 & 67,3 & 30,1 & 2,6 \\
Non-exporters & 100.0 & 68,0 & 30,2 & 1,8 \\
Exports of goods (column \%) & 100.0 & 23,0 & 26,9 & 50,1 \\
Exporters & 100.0 & 100.0 & 100.0 & 100.0 \\
Non-exporters & 98,3 & 99,4 & 98,5 & 66,9 \\
& 1,7 & 0,6 & 1,5 & 33,1 \\
\hline
\end{tabular}

Table 16: Icelandic database population 2014. By size class

\begin{tabular}{|c|c|c|c|c|}
\hline & $\begin{array}{r}\text { Number of enter- } \\
\text { prises }\end{array}$ & Employment & $\begin{array}{r}\text { Number of enter- } \\
\text { prises }(\%)\end{array}$ & $\begin{array}{r}\text { Employment } \\
(\%)\end{array}$ \\
\hline All enterprises & 24,775 & 98,073 & 100.0 & 100.0 \\
\hline SMEs & 24,717 & 71,709 & 99,8 & 73,1 \\
\hline Large enterprises & 58 & 26,364 & 0,2 & 26,9 \\
\hline
\end{tabular}

Table 17: New enterprises in Icelandic database population 2008-2011

\begin{tabular}{lrrrrr} 
& All four years & 2008 & $\mathbf{2 0 0 9}$ & $\mathbf{2 0 1 0}$ & 2011 \\
\hline All new enterprises & 3,850 & 973 & 1,087 & 935 & 855 \\
Born globals & 188 & 35 & 59 & 52 & 42 \\
Other new enterprises & 3,662 & 938 & 1,028 & 883 & 813 \\
\hline
\end{tabular}

\section{Country details: Norway}

This document is based on two data sources, total exports of goods and exports of goods from Mainland Norway. The first source (Eurostat data on the total exports of goods) covers the general overview and analysis of Norwegian exports in chapter 1 . The other source (exports of goods from Mainland Norway in the national micro-data database) covers the analysis of exporters and non-exporters etc. on data linked at micro-level. 
The Norwegian population in the national database covers, in 2014, 286,251 enterprises with a total of 1.26 million employees (in full-time equivalents).

The enterprises categorised as exporters account for $94.9 \%$ of the total value of goods exports in the national database.

Table 18: Norwegian database population 2014

$\begin{array}{lrrrr} & \text { Total } & \text { Manufacturing } & \text { Wholesale } & \text { Other sectors } \\ \text { Number of enterprises } & & & \\ \text { Exporters } & 286,251 & 17,016 & 25,480 & 243,755 \\ \text { Non-exporters } & 4,188 & 1,363 & 1,131 & 1,694 \\ \text { Employment } & 282,063 & 15,653 & 24,349 & 242,061 \\ \text { Exporters } & 1,256,699 & 227,387 & 132,911 & 896,401 \\ \text { Non-exporters } & 158,632 & 96,789 & 10,582 & 51,261 \\ \text { Exports of goods (row \%) } & 1,098,068 & 130,598 & 122,330 & 845,140 \\ \text { Exporters } & 100.0 & 57.4 & 15.4 & 27.2 \\ \text { Non-exporters } & 100.0 & 58.6 & 15.2 & 26.2 \\ \text { Exports of goods (column \%) } & 100.0 & 35.9 & 18.5 & 45.6 \\ \text { Exporters } & 100.0 & 100.0 & 100.0 & 100.0 \\ \text { Non-exporters } & 94.9 & 96.8 & 93.8 & 9.0 \\ & 5.1 & 3.2 & 6.2 & 8.6\end{array}$

Table 19: Norwegian database population 2014. By size class

\begin{tabular}{|c|c|c|c|c|}
\hline & $\begin{array}{r}\text { Number of enter- } \\
\text { prises }\end{array}$ & Employment & $\begin{array}{r}\text { Number of enter- } \\
\text { prises (\%) }\end{array}$ & $\begin{array}{r}\text { Employment } \\
(\%)\end{array}$ \\
\hline All enterprises & 286,251 & $1,256,699$ & 100.0 & 100.0 \\
\hline SMEs & 285,703 & 806,730 & 99.8 & 64.2 \\
\hline Large enterprises & 548 & 449,969 & 0.2 & 35.8 \\
\hline
\end{tabular}

Table 20: Norwegian database population 2014. By ownership

\begin{tabular}{|c|c|c|c|c|}
\hline & $\begin{array}{r}\text { Number of enter- } \\
\text { prises }\end{array}$ & Employment & $\begin{array}{r}\text { Number of enter- } \\
\text { prises (\%) }\end{array}$ & $\begin{array}{r}\text { Employment } \\
(\%)\end{array}$ \\
\hline All enterprises & 286,251 & $1,256,699$ & 100.0 & 100.0 \\
\hline $\begin{array}{l}\text { Domestically controlled } \\
\text { without foreign affiliates }\end{array}$ & 278,735 & 847,389 & 97.4 & 67.4 \\
\hline $\begin{array}{l}\text { Domestically controlled } \\
\text { with foreign affiliates }\end{array}$ & 551 & 111,051 & 0.2 & 8.8 \\
\hline Foreign controlled & 6,965 & 298,260 & 2.4 & 23.7 \\
\hline
\end{tabular}


Table 21: New enterprises Norwegian database population 2008-2011

\begin{tabular}{|c|c|c|c|c|c|}
\hline & All four years & 2008 & 2009 & 2010 & 2011 \\
\hline All new enterprises & 64,730 & 17,788 & 14,594 & 15,718 & 16,630 \\
\hline Born globals & 1,385 & 368 & 301 & 372 & \\
\hline Other new enterprises & 63,345 & 17,420 & 14,293 & 15,346 & 16,286 \\
\hline
\end{tabular}

\section{Country details: Sweden}

The Swedish population covers, in $2014,661,317$ enterprises with a total of 2.3 million employees (in full-time equivalents).

The enterprises categorised as exporters account for $98.5 \%$ of the total value of goods exports in the national database.

Table 22: Swedish database population 2014

\begin{tabular}{lrrrr} 
& Total & Manufacturing & Wholesale & Other sectors \\
Number of enterprises & 661,317 & 51,908 & 65,368 & 544,041 \\
Exporters & 9,398 & 4,234 & 3,325 & 1,839 \\
Non-exporters & 651,919 & 47,674 & 62,043 & 542,202 \\
Employment & $2,272,296$ & 521,193 & 256,871 & $1,494,232$ \\
Exporters & 466,173 & 361,248 & 54,770 & 50,155 \\
Non-exporters & $1,806,123$ & 159,945 & 202,101 & $1,444,077$ \\
Exports of goods (row \%) & 100.0 & 78.3 & 12.6 & 9.2 \\
Exporters & 100.0 & 79.0 & 12.1 & 8.9 \\
Non-exporters & 100.0 & 28.2 & 47.0 & 24.8 \\
Exports of goods (column \%) & 100.0 & 100.0 & 100.0 & 100.0 \\
Exporters & 98.5 & 99.5 & 94.5 & 96.0 \\
Non-exporters & 1.5 & 0.5 & 5.5 & 4.0 \\
\hline
\end{tabular}

Table 23: Swedish database population 2014. By size class

\begin{tabular}{lrrrr} 
& $\begin{array}{r}\text { Number of enter- } \\
\text { prises }\end{array}$ & Employment & $\begin{array}{r}\text { Number of enter- } \\
\text { prises (\%) }\end{array}$ & $\begin{array}{r}\text { Employment } \\
(\%)\end{array}$ \\
All enterprises & 661,317 & $2,272,296$ & & 100.0 \\
SMEs & 660,469 & $1,511,856$ & 99.9 & 100.0 \\
Large enterprises & 848 & 760,440 & 0.1 & 66.5 \\
& & & 33.5 \\
\hline
\end{tabular}


Table 24: Swedish database population 2014. By ownership

\begin{tabular}{|c|c|c|c|c|}
\hline & $\begin{array}{r}\text { Number of enter- } \\
\text { prises }\end{array}$ & Employment & $\begin{array}{r}\text { Number of enter- } \\
\text { prises (\%) }\end{array}$ & $\begin{array}{r}\text { Employment } \\
(\%)\end{array}$ \\
\hline All enterprises & 661,317 & $2,272,296$ & 100.0 & 100.0 \\
\hline $\begin{array}{l}\text { Domestically controlled } \\
\text { without foreign affiliates }\end{array}$ & 647,009 & $1,666,491$ & 97.8 & $73 \cdot 3$ \\
\hline $\begin{array}{l}\text { Domestically controlled } \\
\text { with foreign affiliates }\end{array}$ & 2,222 & 71,474 & 0.3 & 3.1 \\
\hline Foreign controlled & 12,086 & 534,331 & 1.8 & 23.5 \\
\hline
\end{tabular}

Table 25: New enterprises in Swedish database population 2008-2011

\begin{tabular}{lrrrrr} 
& All four years & 2008 & 2009 & 2010 & 2011 \\
\hline All new enterprises & 156,199 & 36,072 & 36,067 & 39,454 & 44,606 \\
Born globals & 2,000 & 450 & 463 & 542 & 545 \\
Other new enterprises & 154,199 & 35,622 & 35,604 & 38,912 & 44,061 \\
\hline
\end{tabular}


Ved Stranden 18

DK-1061 Copenhagen K

www.norden.org

\section{Services and Goods Exports from the Nordics}

The publication Services and Goods Exports from the Nordics Strongholds and profiles of exporting enterprises analyses the exports of services and goods from the Nordic countries and profiles the exporting enterprises. The report addresses issues such as: What are the strongholds of the Nordic countries, both in terms of the type of exported services and goods and in terms of geographical markets? New data profile for the first time the services trading enterprises in a comparative analysis across the Nordics. How have exporting enterprises performing compared to non-exporting enterprises since the crisis in terms of employment and value added creation? What is the importance of multinationals for the exports from the Nordic countries? The analysis identify the importance of true SMEs compared to SMEs belonging to larger groups and identify the born globals and analyse their survival rate and employment creation compared to other non-exporting newly born enterprises.

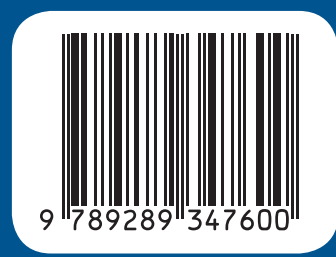

